\title{
Issue 44 (December 2019)
}

ISSN 2627-9827 - DOI 10.21570/EDGG.PG.44
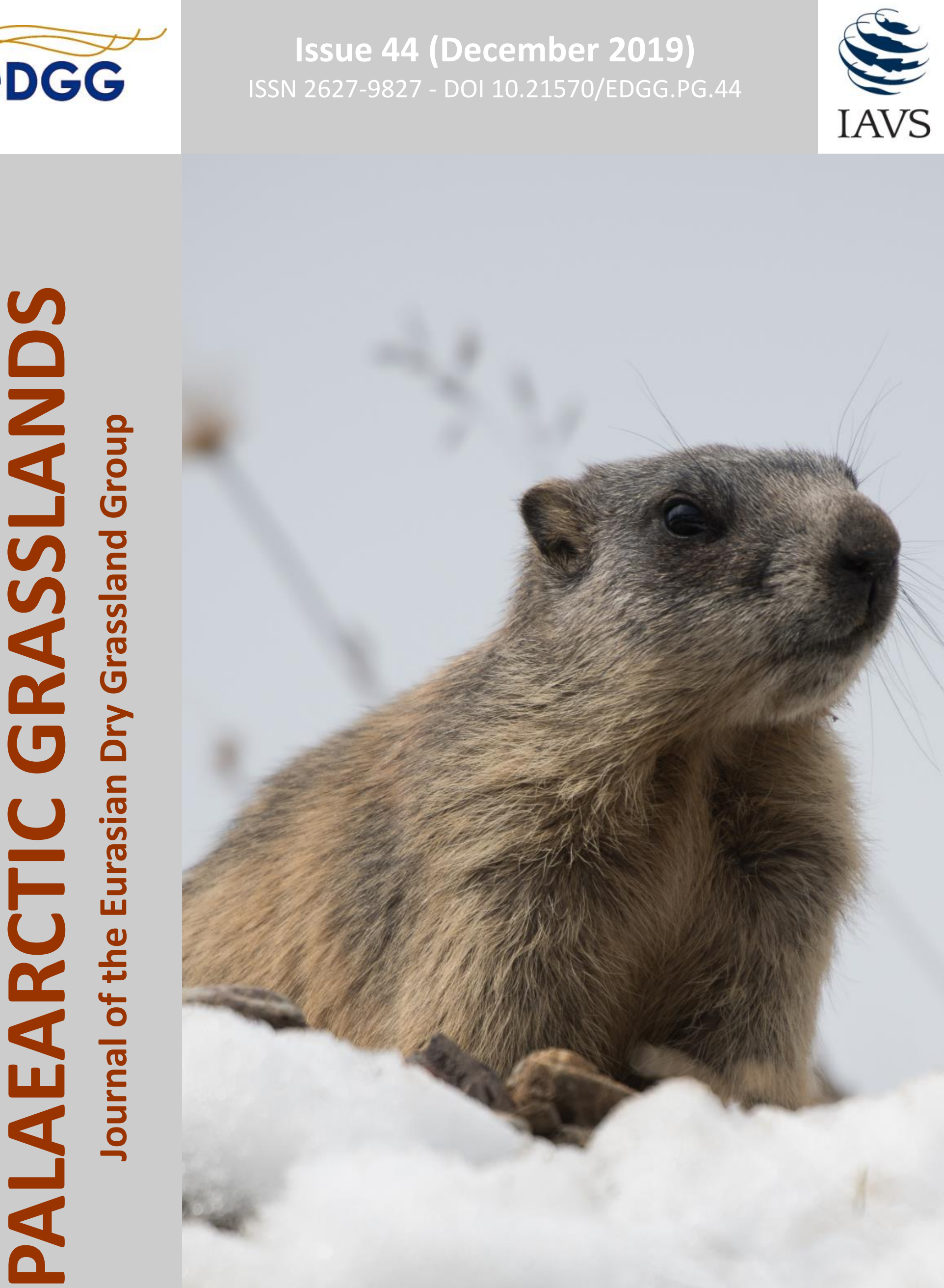


\section{Table of Contents}

Editorial

News

$14^{\text {th }}$ EDGG Field Workshop: Ukrainian steppes along climatic gradients. Second call

Magnes, $M$. et al. Postconference report for the $16^{\text {th }}$ Eurasian Grassland Conference (2019) in Graz, Austria and Maribor, Slovenia

Biurrun, I. et al. GrassPlot v. 2.00 - first update on the database of multi-scale plant diversity in Palaearctic grasslands

Photo Story

Short Contributions

Book Review

\section{Palaearctic Grasslands}

ISSN 2627-9827

DOI 10.21570/EDGG.PG44

Palaearctic Grasslands, formerly published under the names Bulletin of the European Dry Grassland Group (Issues 1-26) and Bulletin of the Eurasian Dry Grassland Group (Issues 27-36) is the journal of the Eurasian Dry Grassland Group (EDGG). It usually appears in four issues per year. Palaearctic Grasslands publishes news and announcements of EDGG, its projects, related organisations and its members. At the same time it serves as outlet for scientific articles and photo contributions.

Palaearctic Grasslands is sent to all EDGG members and, together with all previous issues, it is also freely available at http://edgg.org/publications/bulletin.

The copyright of the included texts, photographs, and other figures remains with their authors. If you wish to re-use them or parts of them, please, obtain the written consent of the authors first.

Scientific articles (Research Articles, Reviews, Forum Articles, Scientific Reports) should be submitted to Jürgen Dengler (juergen.dengler@uni-bayreuth.de), following the Author Guidelines published in Palaearctic Grasslands 37, 6-8. They are subject to editorial review, with one member of the Editorial Board serving as Scientific Editor and deciding about acceptance, necessary revisions or rejection.

All other text contributions (News, Announcements, Short Contributions, Book Reviews,...) should be submitted to Anna Kuzemko (anyameadow.ak@gmail.com) AND Idoia Biurrun (idoia.biurrun@ehu.es). Please check a current issue of Palaearctic Grasslands for the format and style. Deadline for submission to the next issue is 15 January 2020

Photo and art contributions (for general illustrative purposes with captions; proposals for Photo Stories; contributions to Photo and Art Competition) should be submitted to Photo Editor Rocco Labadessa (rocco.labadessa@gmail.com). Deadline for submissions to the next Photo Competition on "Grasses and grasslands" is 15 January 2020.

Contributions to the sections "Recent Publications of our Members" and "Forthcoming Events" should be sent to Iwona Dembicz (i.dembicz@gmail.com).

Photos included in submissions have always to be delivered in two forms, embedded in the document and as separate jpg (or tiff) files with sufficient resolution for printing (i.e. not less than $1 \mathrm{MB}$ ).

Palaearctic Grasslands is published by EDGG c/o Prof. Dr. Jürgen Dengler, Plant Ecology, BayCEER, University of Bayreuth, Universitätsstr. 30, 85447 Bayreuth, Germany.

\section{Editorial Board}

CHIEF EDITOR:

Anna Kuzemko, Ukraine

DEPUTY CHIEF EDITORS:

Idoia Biurrun, Spain

Jürgen Dengler, Switzerland

\section{EDITORAL BOARD:}

Alla Aleksanyan, Armenia

Didem Ambarlı, Turkey

Dolores Byrne, Ireland

Iwona Dembicz, Poland

Edy Fantinato, Italy

Magdalena Firganek-Fulcher, UK

Paul Goriup, UK

Riccardo Guarino, Italy

Richard Jefferson, UK

Gwyn Jones, UK
Rocco Labadessa, Italy

Frank Yonghong Li, China

Ashley Lyons, UK

Lorna Marcham, UK

Jim Martin, Ireland

James Moran, Ireland

Jalil Noroozi, Austria

Arkadiusz Nowak, Poland

Salza Palpurina, Bulgaria

Nina Polchaninova, Ukraine

Solvita Rūsina, Latvia

Stuart Smith, UK

Laura Sutcliffe, Germany

Péter Török, Hungary

Atushi Ushimaru, Japan

Orsolya Valkó, Hungary

Stephen Venn, Finland

On front cover page: Alpine marmot (Marmota marmota) watching out in front of its burrow after an early snowfall in autumn, Upper Engadine, Switzerland. Photo: J. Dengler. 


\section{Editorial}

Dear readers,

These days, when December is unusually mild outside, I do not exclude the possibility that for some of you the field season is still continuing, but for most it is already over. However, this is not a reason to sleep in a warm hole, as the cute animal depicted on the cover of this issue. This is the time for managing field data - samplings, collections, photographs. Moreover, this is a very good time to take stock of the outgoing year and make plans for next year.

2019 was full of events for EDGG. One such event was the Eurasian Grassland Conference (EGC), organized jointly by our members from Austria and Slovenia. In this issue, on pp. 16-25, you will find a report of the conference with many photos, as well as the impressions of some of the participants. For those who participated in the EGC, this is an opportunity to recall the wonderful atmosphere that prevailed during the conference, and for those who could not attend, the report can be an advert, and maybe an incentive to participate in future EGCs.

If you are making plans for your next season of fieldwork, do not overlook the second call of our second annual event, the EDGG Field Workshop, which will be held in southern Ukraine, and the aim of which is to collect steppe vegetation data along climatic gradients (pp. 6-15). The boundless fields of feather grass - the plant in our logo - in the illustrations for this call will say more than any words for true lovers of steppes, about the attractiveness of the sites that participants will visit during the Field Workshop.

The main result of the previous research expeditions and field workshops are high-quality data, which are stored in the GrassPlot database. The "Scientific report", on pages 26 -47 , presents the progress that has been made in the content and functionality of this database, which currently includes more than 190,000 high-quality grassland plots.

Christmas or the New Year are good times to give presents. If you have the desire and possibility to support our group and its activities financially, you will find detailed information on how to do this on page 4.

We hope that during these festive winter days you will find time to read the new issue of our journal. Thank you for being with us during the past year and we hope to meet with many of you in the year to come!

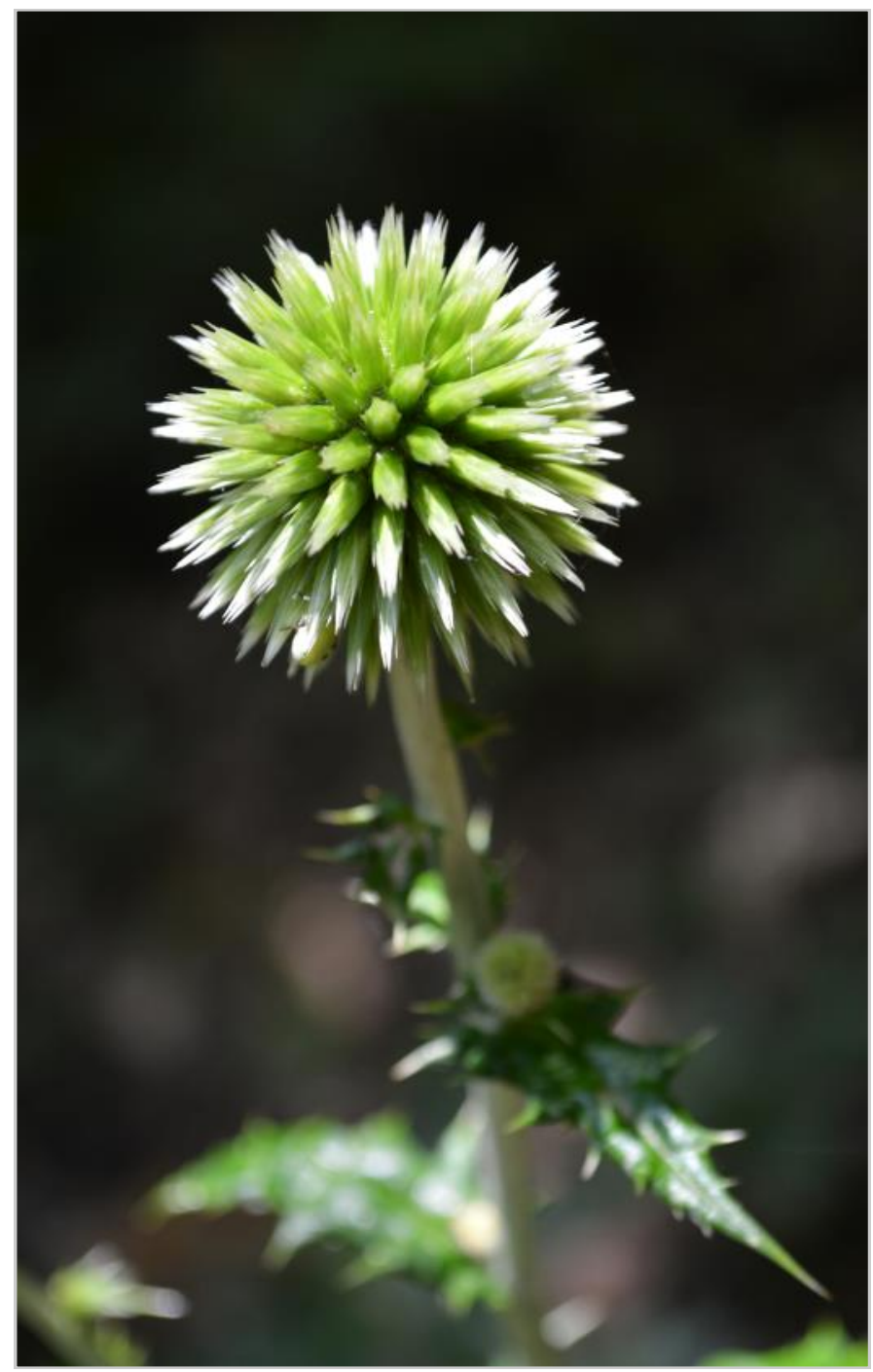

Echinops siculus, Puglia, Italy. Photo: R. Labadessa.

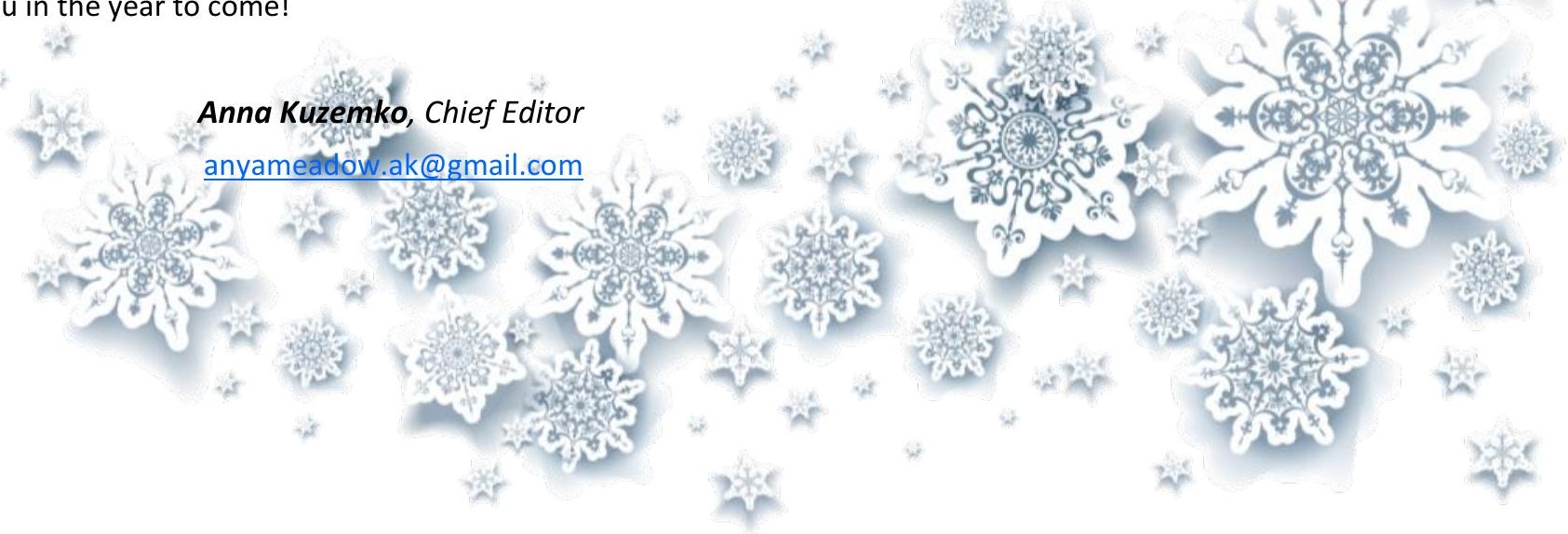




\section{News}

\section{Charitable Donations}

Dear members of the EDGG,

With this year approaching its end, we would like to thank all EDGG members who actively contributed to the Eurasian Grassland Conference, our Field Workshops, our journal Palaearctic Grasslands, our website, special features, book chapters and databases in 2019 and made them a big success.

As you know, EDGG is a non-for-profit organization and since its establishment in 2008 it has offered a wide variety of services to the community of grassland ecologists and conservationists without charging any membership fees. This has been made possible through the enthusiasm of many of our members and some financial support from our mother organization, IAVS. However, we realise more and more often that we are short of money to support our wide range of activities. In particular we would like to allow more scientists with limited or no financial resources to participate in our annual conferences and field workshops, and provide linguistic editing for articles prepared by non-native speakers in our publications.

As in the previous year, we have decided to ask for your support in form of CHARITABLE DONATIONS of money to EDGG. Those of you who would like to provide some voluntary financial contributions are cordially invited to make use of this opportunity.

We appreciate any contribution be it small or large!

\section{HOW TO CONTRIBUTE?}

Please make your transfer to the following account:

Account holder: IAVS

Bank: SNS Bank

IBAN: NL40 SNSB 0921529023

Swift for the bank: SNSBNL2AXXX

Address:

Head Office, Utrechtsestraat $466800 \mathrm{Hw}$ Arnhem, All Dutch Offices, Netherlands

IAVS Business Office, 9650 Rockville Pike, Bethesda, MD 20814 USA

Currency: EUR

Please include the following text: Donation to IAVS working group EDGG

To keep track of the donations, please additionally send a short e-mail to our treasurer, Péter Török (molinia@gmail.com), indicating when you transferred what amount of money to our account. If you wish, you can also indicate in your mail to Péter that your donation is used for one of the following main purposes:

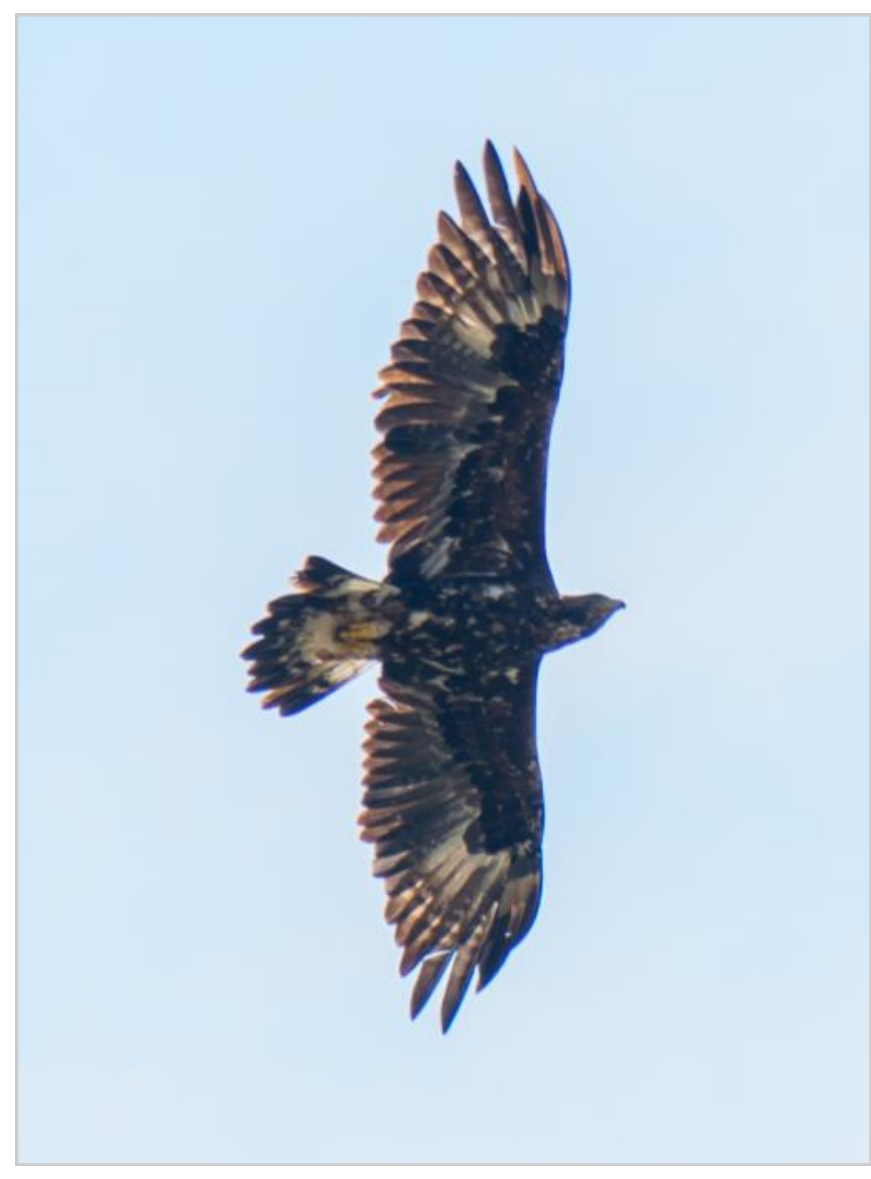

Golden eagle (Aquila chrysaetos) circling above steppic grasslands in the canton of Valais, Switzerland. Photo: J. Dengler.

1 - Travel grants for the Eurasian Grassland Conferences 2 - Travel grants for the EDGG Field Workshops

3 - Linguistic editing for articles by non-native speakers in our publications

If you do not make such an indication, the Executive Committee will spend the money, where it is most needed. We intend to acknowledge those members who support our work financially in the next issue of Palaearctic Grasslands. However, if you prefer to remain anonymous, please inform Péter.

Many thanks for your continued support to EDGG, be it ideally, actively or financially.

We wish you calm and pleasant days at the end of the year and a Happy New Year,

The EDGG Executive Committee

(Alla Aleksanyan, Didem Ambarli, Idoia Biurrun, Iwona Dembicz, Jürgen Dengler, Anna Kuzemko, Péter Török, Stephen Venn) 


\section{Photo Story and Photo Competition}

The call for the current Photo Competition is dedicated to the theme "Grasses and grasslands", looking for photographs that best highlight the beauty of grasses (Poaceae), either depicting the neglected beauty of grass details or underlining their exceptional importance in grassland structure.

You are invited to send up to three high-quality photographs within the competition theme (full size JPEG or TIFF images, at least $300 \mathrm{dpi}$ ) together with captions giving information on the subject (species name, date, place name) and, possibly, technical details (camera, lens, aperture and exposure time).

The selection will be made by a jury of at least five members from the Editorial Board of the journal. The three best shots will be awarded with full space in the next issue, but we reserve the right to use further submitted materials for illustrative purposes in other parts of the issue.

If you feel you can contribute with your shots, don't be shy! Everyone can join the competition!
Contributions for the Photo Story section are always welcome. Photo Story is an open space where members can submit their own photo collection on a certain grasslandrelated topic of their choice. High-quality photos should be provided together with their captions (at least species names or landscape description), a brief text and possibly other graphical elements (like a map or a drawing). The selection of photos should fit for 1-4 pages and the proponents should already propose a preliminary layout (in PDF or MS Word format), which will be finally typeset by Editors. As an example, you may take a look at the Photo Stories published in previous PG issues.

If you want to contribute to these sections, or if you simply want to help us enriching the aspect of the journal, please submit your photos together with required information to Rocco (rocco.labadessa@gmail.com).

Deadline for photo submissions is $\mathbf{1 5}$ January 2020 !

Rocco Labadessa, Bari, Italy rocco.labadessa@gmail.com

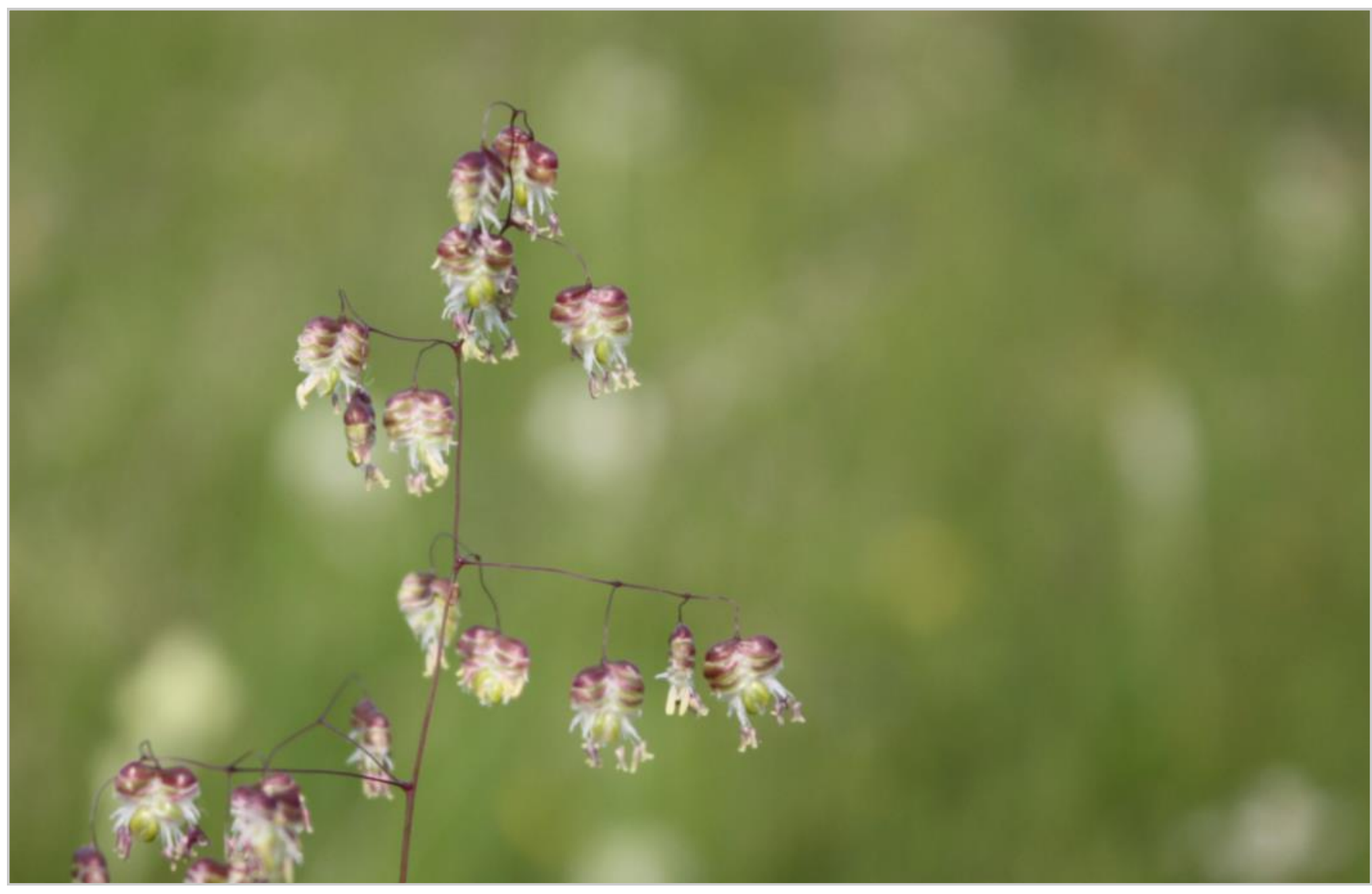

Briza media at Carpathian meadow, National Nature Park "Hutsulshchyna”, Ukraine. Photo: A. Kuzemko. 


\title{
$14^{\text {th }}$ EDGG Field Workshop: Ukrainian steppes along climatic gradients
}

\author{
Ukraine, 25 May - 3 June 2020
}

\section{Second Call}

\section{Background}

The history of EDGG Field Workshops began in 2009 in Romania (Dengler et al. 2009). Before 2014 these events were called "EDGG Research Expeditions". Up to now, 13 Field Workshops have been organized: Romania (2009), Ukraine (2010), Bulgaria (2011), Italy (Sicily) (2012), Greece (2012), Russia (2013), Spain (2014), Poland (2015), Serbia (2016), Italy (Central Apennines) (2017), Austria (2018), Switzerland (2019) and Armenia (2019).

The aim of Field Workshops is to sample different taxa groups in grasslands (mainly vascular plants, mosses and lichens) across multiple scales (from 0.0001 to $100 \mathrm{~m}^{2}$ ) using a standardized methodology (Dengler et al. 2016). Some animal taxa have also been sampled in several expeditions together with vegetation data, for example spiders (Polchaninova et al. 2018), leafhoppers (Filibeck et al. 2018), and butterflies (Magnes et al. 2018). The results obtained from the analyses of high-quality data from several expeditions have been already published: Romania (Dengler et al. 2012; Turtureanu et al. 2014), Bulgaria (Pedashenko et al. 2013), Ukraine (Kuzemko et al. 2014, 2016) and Russia (Polyakova et al. 2016).

These expeditions served as the basis for the creation of the "GrassPlot" Database which focuses on precisely delimited plots of eight standard grain sizes $(0.0001 ; 0.001 ; \ldots 1,000$ $\mathrm{m}^{2}$ ) and on nested-plot series with at least four different grain sizes (Dengler et al. 2018). In total, the database now comprises a total of 190,673 plots, with 4,654 nested-plot series including at least four grain sizes (Biurrun et al. 2019).

\section{Applications}

All EDGG members are welcome to apply to participate in EDGG Field Workshop via the website www.edgg.org/ after $7^{\text {th }}$ January 2020. Deadline for applications is $15^{\text {th }}$ February 2020. Confirmation of participation and feedback on travel grant applications will be given not later than 1 March 2020.

All applicants except those who already participated in four or more Field Workshops have to submit a motivation letter (200 words maximum), explaining why they are interested in participation and what they would contribute its success during and after the Field Workshop. High priority will be given to applicants who are willing to carry out the soil analyses afterwards. Experts of non-plant taxa, such as grasshoppers, leafhoppers, spiders, butterflies, fungi or soil metagenomics are also welcome to join if they are able and willing to carry out their sampling in a way that allows joint analyses with the vegetation diversity data. Such applicants are requested to discuss a potential sampling design prior to application with Iwona Dembicz and Idoia Biurrun and to clarify with the local organizer whether there are any legal constraints. The motivation letter is the most important criterion if there are more applications for participation than places or for travel grants than money available.

\section{Travel grants}

Travel grants are provided by our parent organization IAVS, and they are only available to members of IAVS in 2020. Priority for travel grants will be given to the following groups of persons: a) students and other applicants from low-income countries; b) well-established and very active participants of previous Field Workshops; c) persons that have already agreed to organize a Field Workshop in the coming years or provide any additional input such as soil analyses or sampling and identification of taxonomic groups other than vascular plants. The final decision will depend on the combination of these three variables. The amount of money provided to a particular grantee is not a fixed sum, but depends on the available money, the demonstrated need of the respective person and his/her relevance to the success of the Field Workshop. Accordingly travel grants can cover parts of the registration fee, the full registration fee or possibly even the travel costs to get to the event.

IAVS and EDGG requires their grantees to be actively involved in the EDGG event and contribute to its success. In case of FW, it is necessary that all participants work intensively during and after the FW to obtain high-quality scientific results. Some of the tasks shared by participants are data entry and digitizing data, sorting and analyzing soil samples, preparing and identification of plant specimens. Post-FW tasks usually require a few days of work for each participant. Participants will be invited as a co-author to one or more publications using these data. It is required that IAVS grantees accept to fulfill tasks relevant to their exper- 


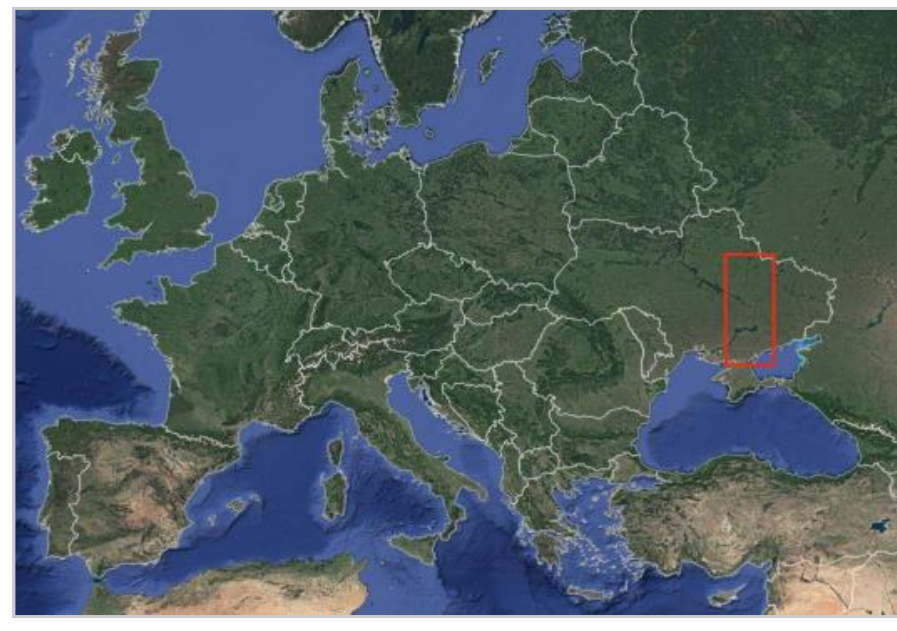

Fig. 1. Location of the study area (red rectangle) in the European context. Map data C2019 Google, ORION-ME.

tise and capabilities during and after the FW. If a grantee does not fulfill the post-FW task, he or she may be exempted from next year's grants for EDGG events.

\section{Fees}

The fees comprise all costs of meals, travel and accommodation starting on 25 May in Kherson and ending on 03 June in Kyiv (Boryspil airport), with the possibility to return to Kherson.

The fees for full participation are:

- $650 €$ for postdocs, senior scientists or other regularly employed persons who are not IAVS members

- $600 €$ for postdocs, senior scientists or other regularly employed persons who are IAVS members

- $600 €$ for students (including PhD students) and unemployed persons who are not IAVS members

- $550 €$ for students (including PhD students) and unemployed persons who are IAVS members

After decision on the final list of participants and on travel grants, each participant will receive an invoice with the amount of money to be paid. Payment has to be made in cash on the first day of participation.

For cancellations, we charge the following fees:

- Until 10 April: 50\% of your regular fees

- After 10 April: $80 \%$ of your regular fees

\section{Topic and aims of the Field Workshop}

The $14^{\text {th }}$ EDGG Field Workshop will be held in Ukraine for the second time. The first was ten years ago, in 2010, in Central Podolia, Vinnytsia region (Dengler et al. 2010). During that expedition, 21 nested-plot series $\left(0.0001\right.$ to $\left.100 \mathrm{~m}^{2}\right)$ and 184 normal plots $\left(10 \mathrm{~m}^{2}\right)$ were sampled, covering the full variety of dry grasslands, mainly meadow steppes and rocky grasslands (Kuzemko et al. 2014).

The new expedition will take place in Southern and Central Ukraine (Fig. 1). We will work in Kherson, Zaporizhzhia,
Dnipro, Kharkiv and Poltava administrative regions. The main aim will be to investigate plant richness patterns of steppe grasslands along climatic gradients (precipitation and temperature) from the driest semi-desert communities in the south to the meadow steppes in the north.

\section{The study area}

The research area is flat and lies within the East European Plain (Fig. 1). The southern part belongs to the Black Sea Lowland, the northern part - to the Dnipro Lowland (Poltava plain). The central part of the study area is divided by the Dnipro River into two parts, one lies on the left bank of the river (Dnipro Lowland), the other steep right bank belongs to the Dnipro Upland.

The Dnipro glacier, which covered almost the entire surface of the northern part of the expedition route in the foreststeppe zone, was extremely important for the formation of the modern relief. Therefore, the plateau is cut not only by contemporary river valleys, but also by numerous ancient valleys and gullies because of the glacier melting. All the research area is covered by loess and loess-like deposits 20 $25 \mathrm{~m}$ depth, sometimes exposed. These sediments form the Ukrainian loess belt, which is one of the biggest loess formations in the world (Muhs 2007). In the central part within the Dnipro Upland, the surface of the Precambrian foundation lies above sea level and forms granitic outcrops.

The climate is continental. It corresponds to three types according to Köppen climate classification (Beck et al. 2018): BSk - Arid, steppe, cold; Dfa - Cold, no dry season, hot summer; Dfb - Cold, no dry season, warm summer. On the southernmost area mean annual temperature is $10.3^{\circ} \mathrm{C}$ and mean annual precipitation is $399 \mathrm{~mm}$. While in the northernmost part of the research area they are $8.9^{\circ} \mathrm{C}$ and 591 $\mathrm{mm}$ respectively (Fig. 2). On Fig. 3 we represent Walter and Lieth climatic diagrams built using "climatol" R package (Guijarro 2019) and Worldclim Version 2.0 (Fick \& Hijmans 2017) for some of the localities for the expedition.

Soil types above the loess vary depending on climate and vegetation type. The main soils are chernozems with different humus content and different soil depths. Other soil types also occur - kastanozems, podzols, alfisols and others. Sometimes chernozem is influenced by salinity and replaced by solonetz and solonchak varieties. According to the physiographic zonation of Ukraine (Popov et al. 1968), the soils are dark and typical kastanozems (chestnut soils) of 40-50 $\mathrm{cm}$ depth and $2.5-4 \%$ humus content on the southernmost part of the expedition route. Moving to the north they are replaced by southern saline chernozems $(45-50 \mathrm{~cm}$ depth, $4 \%$ humus content), afterwards by southern low-humus chernozems $(60-70 \mathrm{~cm}, 5 \%)$, common low-humus chernozems (60-65 cm, 5.5-6\%), and common chernozems (70-100 $\mathrm{cm}, 6.8-7.2 \%)$, and finally by deep chernozems $(115-130 \mathrm{~cm}$, $6-8 \%)$ in the northernmost steppe part. Podzols and alfisols are also present under the forests in the forest-steppe zone. 

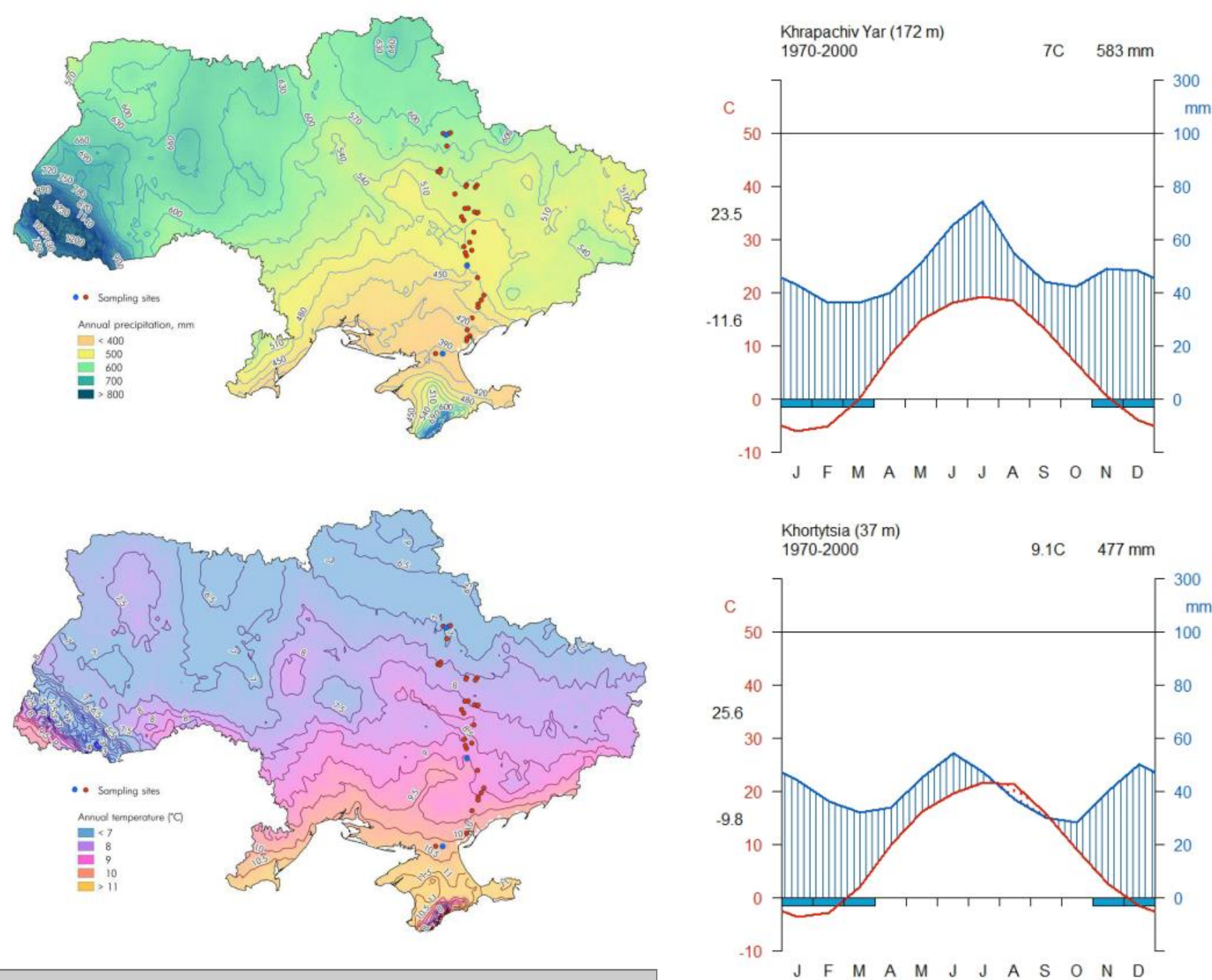

Fig. 2. Maps of Ukraine with approximate sampling locations with contour lines of annual precipitation (on the top) and mean annual temperature (at the bottom). Blue dots represent localities shown on Fig. 3.

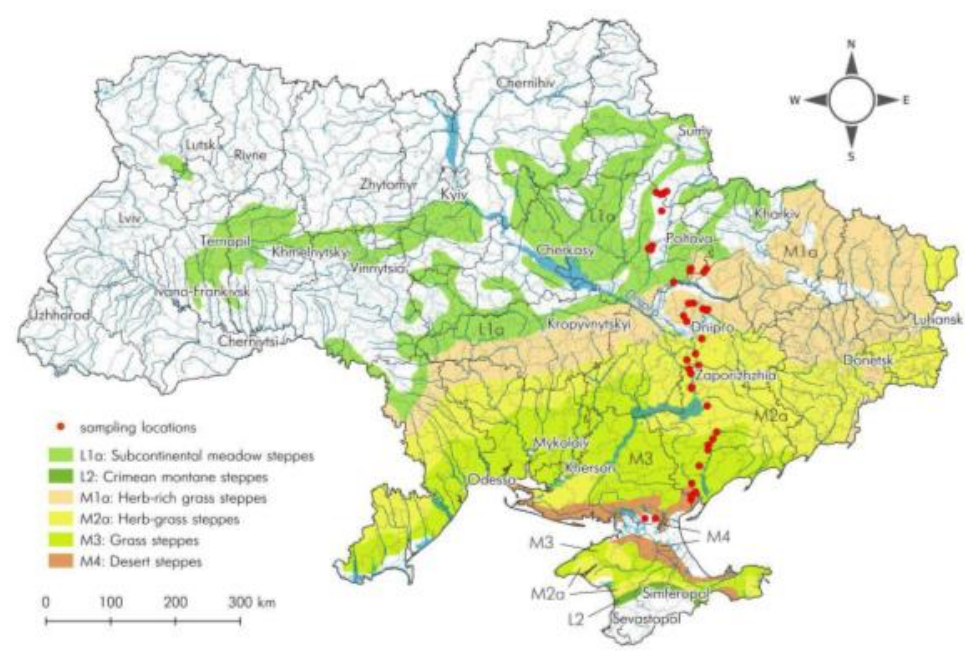

Fig. 4. Map of Ukraine with approximate sampling locations. Vegetation types based on the potential natural vegetation map of Europe (Bohn et al. 2000).

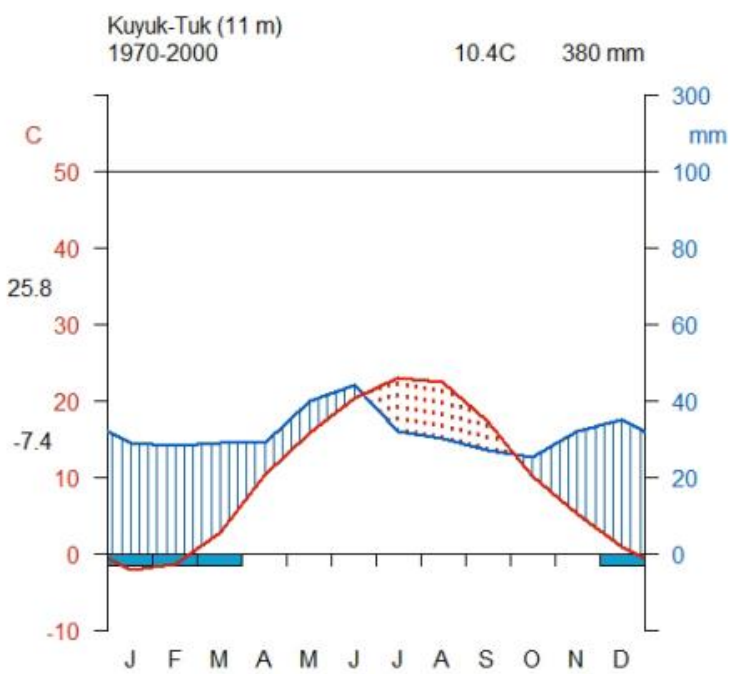

Fig. 3. Walter and Lieth climate diagrams on some localities of the expedition. A: Khrapachiv Yar village, ending point (N 50.260, E 34.499); B: Khortytsia Island, mid-workshop point (N 47.810, E 35.099); C: Kuyuk-Tuk Island, starting point (N 46.072, E 34.407). 


\section{Flora and vegetation}

Several physiognomic classification systems arrange steppe types along climatic (latitudinal) gradients and therefore each steppe type corresponds to a zonal vegetation type (Hurka et al. 2019). In Ukraine, the most common way to determine steppe types is based on the dominant approach, which is based on the main dominant species of communities - "edificators". Higher units traditionally include the following climatic steppe types: desertified steppes, bunchgrass steppes, forb-bunchgrass steppes and meadow steppes (Bilyk et al. 1973). Another similar classification system of zonal steppe types was used in the Map of the Natural Vegetation of Europe (Bohn et al. 2000), according to which the following steppe types are recognized in Ukraine along an increasing precipitation gradient from south to north: desert steppes, grass steppes, herb-grass steppes, herb-rich grass steppes, Crimean montane steppes, subcontinental meadow steppes (Fig. 4).

The classification of vegetation based on complete species lists has not been commonly applied in Ukraine, but it is currently being developed. It still needs clarification and large-scale comparison to distinguish the most suitable units. Desertified salt steppes are classified within the alliance Artemisio tauricae-Festucion described from Crimea. Dominants of such communities are Festuca valesiaca, Agropyron cristatum and Artemisia taurica (Kolomiychuk \& Vynokurov 2016). We will sample them during the first day in the Sivash Lake region within the Azovo-Syvashskyi National Nature Park (Churiuk and Kuyuk-Tuk Islands) (Figs. 5, 6, 7).

For the bunchgrass steppes, the alliance Tanaceto millefoliiGalatellion villosae was proposed (Kolomiychuk \& Vynokurov 2016). This unit combines communities with Agropyron cristatum, Astragalus ponticus (Fig. 8), Bassia prostrata, Ephedra distachya, Goniolimon tataricum, Stipa ucrainica,
Tanacetum millefolium and Vincetoxicum maeoticum (Fig. 9), which do not occur or only rarely in more humid climates. This type of vegetation will be sampled during the $2^{\text {nd }}$ and $3^{\text {rd }}$ day of the Field Workshop on the slopes of Syvashyk Liman, Utliutsky Liman, Velykyi Utliuk, Tashhenak and Molochna River Valleys, Troitska Balka. These sites preserve many endangered steppe species such as Allium regelianum, A. pervestitum, Astragalus reduncus, A. pallescens, Caragana scythica, Cymbochasma borysthenica, Rhaponticoides taliewii, Tulipa gesneriana (Kostyliov et al. 1994; Kolomiychuk et al. 2012).

More to the north, bunchgrass steppes are replaced by forb -bunchgrass true steppe communities, which are classified within the alliance Stipo lessingianae-Salvion nutantis. These communities are characterized by such species as Astragalus austriacus, Bellevalia speciosa (Fig. 10), Euphorbia nicaeensis subsp. stepposa, Galatella villosa, Jurinea arachnoidea, Nepeta ucranica subsp. parviflora, Phlomis herba-venti subsp. pungens (Fig. 11), Teucrium polium, and Viola ambigua. We will sample these communities during the following five days in Zaporizhzhia, Dnipro, Poltava and Kharkiv regions. Natural vegetation can be found in the river valley systems (Dnipro, Samara, Kil'chen: Fig. 12, Oril River Valleys).

In the forest-steppe zone true steppe vegetation is replaced by meadow steppes which can be classified within the alliances Festucion valesiacae or Cirsio-Brachypodion pinnati. These communities are dominated by grasses (Elytrigia intermedia, Festuca stricta subsp. sulcata, Stipa capillata, S. pennata, S. tirsa,) and forbs (Filipendula vulgaris, Salvia pratensis, Trifolium montanum, etc.). We will sample these vegetation type during the $6^{\text {th }}$ and $9^{\text {th }}$ days of the expedition, in the vicinity of Poltava and Zin'kiv.

Fig. 13 shows the diversity of steppe types we will sample during the Field Workshop.

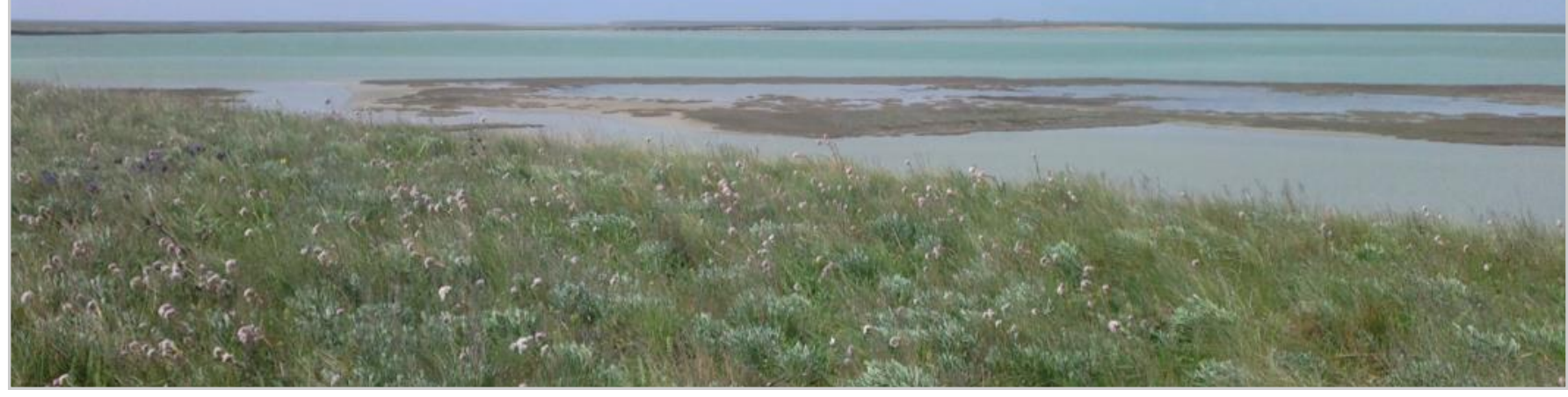

Fig. 5. Syvash Lake. Photo: D. Vynokurov. 


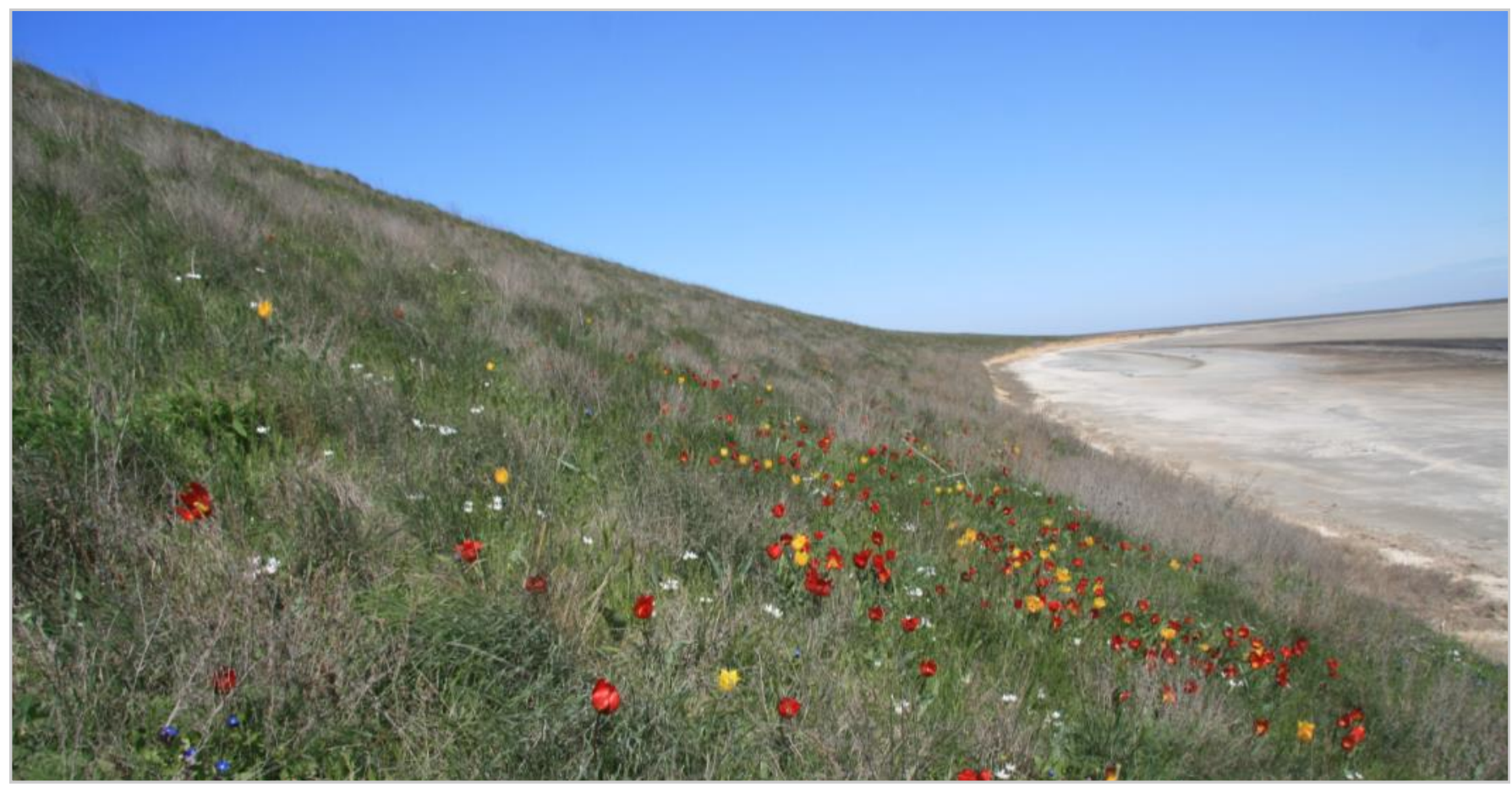

Fig. 6. Kuyuk-Tuk Island. Photo: M. Peregrym.

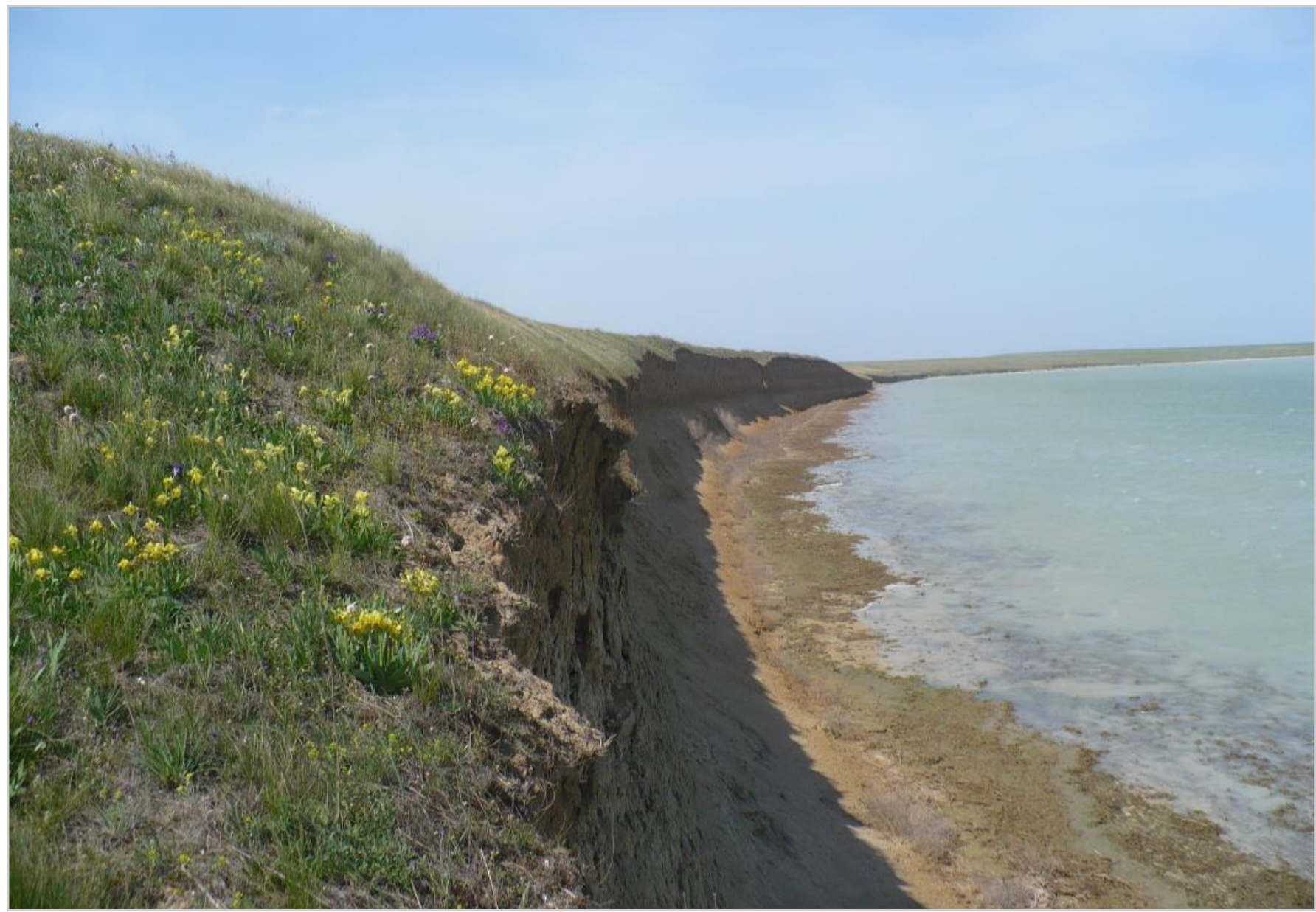

Fig. 7. Slopes of Churiuk Island and Syvash Lake. Photo: D. Vynokurov. 


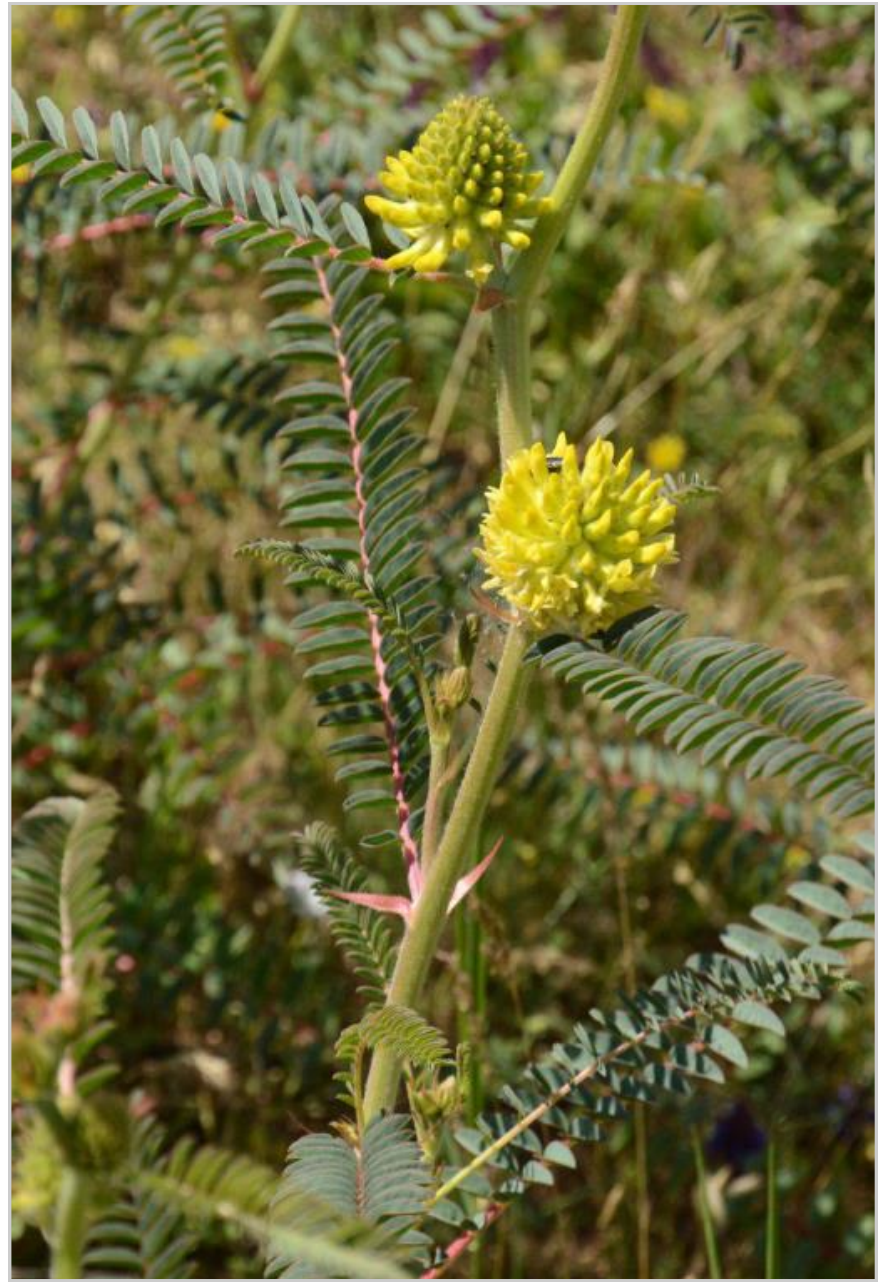

Fig. 8. Astragalus ponticus. Photo: D. Shyriaieva.

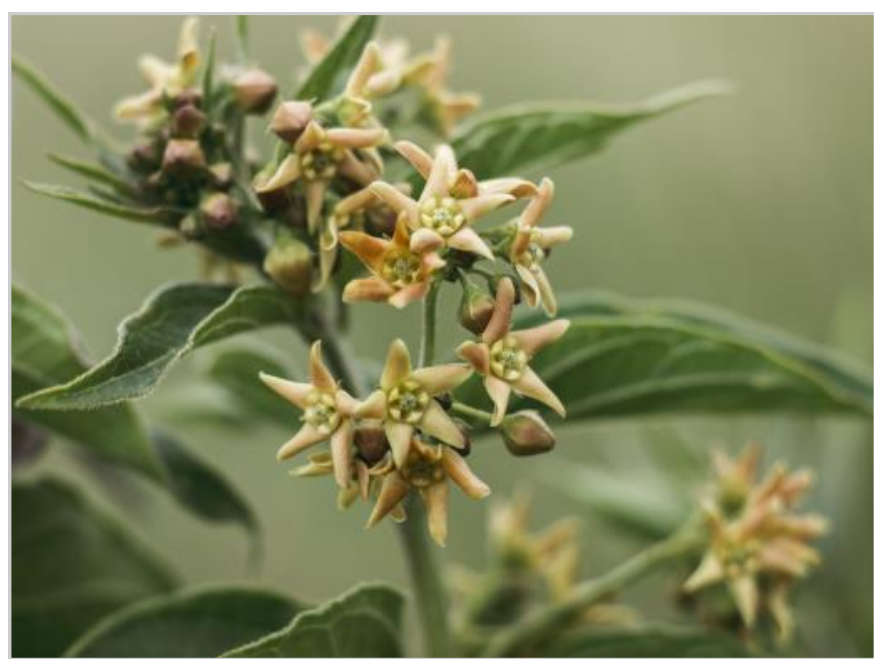

Fig. 9. Vincetoxicum maeoticum. Photo: D. Vynokurov.

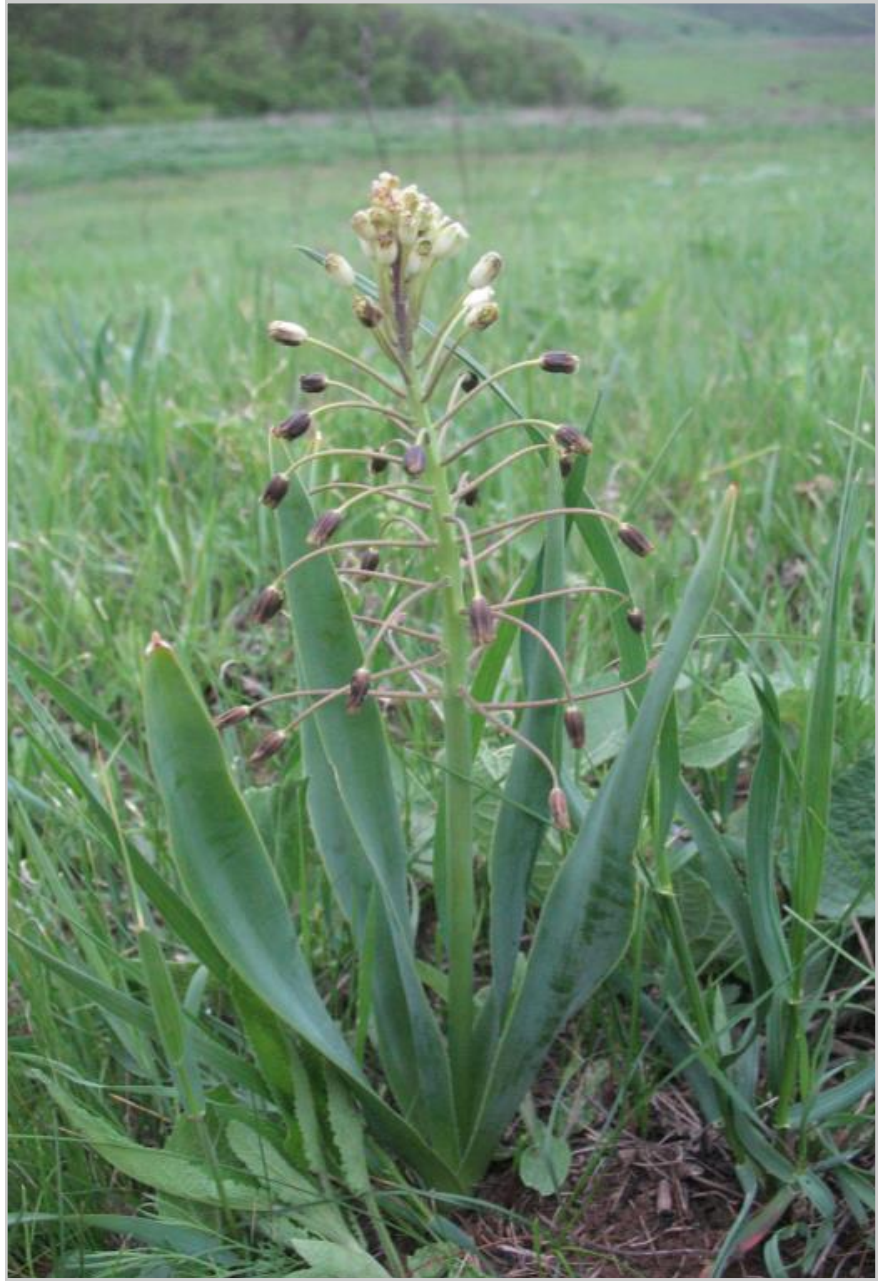

Fig. 10. Bellevalia speciosa. Photo: I. Moysiyenko.

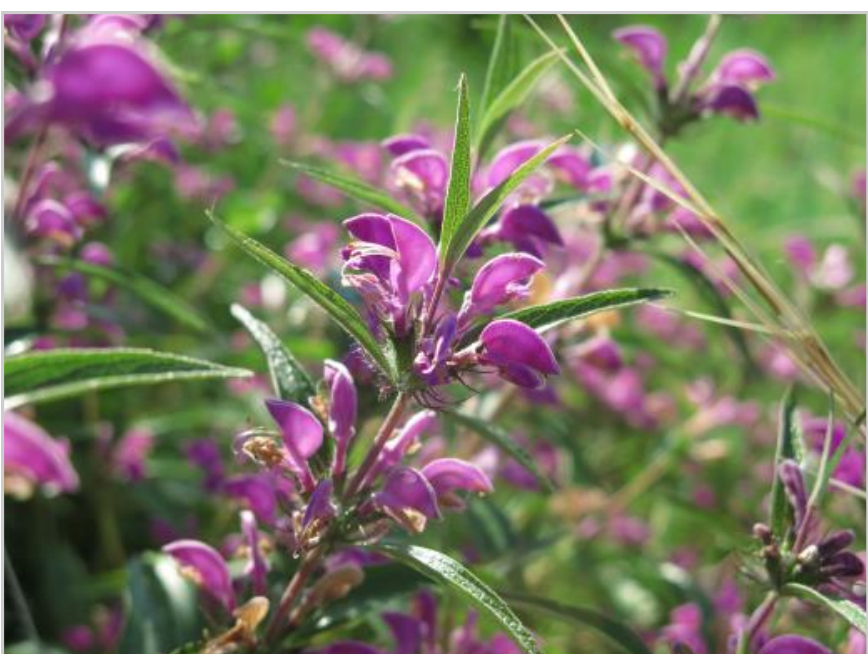

Fig. 11. Phlomis herba-venti subsp. pungens. Photo: V. Maniuk. 
Preliminary syntaxonomical scheme of Festuco-Brometea class vegetation of the research area on the alliance level:

Festuco-Brometea Br.-Bl. et Tx. ex Soó 1947

Tanaceto achilleifolii-Stipetalia lessingianae Lysenko \&

Mucina in Mucina et al. 2016

Artemisio tauricae-Festucion Korzhenevsky \& Klyukin 1991

Tanaceto millefolii-Galatellion villosae Vynokurov in Kolomiychuk \& Vynokurov 2016

Festucetalia valesiacae Soó 1947

Stipo lessingianae-Salvion nutantis Vynokurov 2014

Festucion valesiacae Klika 1931

Brachypodietalia pinnati Korneck 1974

Cirsio-Brachypodion pinnati Hadač et Klika in Klika et Hadač 1944d

\section{Preliminary itinerary of the Field Workshop}

Our itinerary is shown in Table 1. We will stay in four different accommodations along our travel from Kherson to Kyiv.

Our sampling sites include the Azovo-Syvashskyi National Nature Park, Pryazovskyi National Nature Park, Regional Landscape Park "Dniprovi Porohy" (Fig. 14) and other locally protected areas. Other dry grasslands are parts of designed natural parks or local nature reserves. Some territories are also protected as sites of the Emerald Network in Ukraine.

\section{Important Travel Information}

Starting point for the Field Workshop is the main train station in Kherson, where we will collect participants. There are two options for getting to Kherson city: (1) flight to Kyiv and then have a night train from Kyiv to Kherson, or (2) flight to Kherson. There are two international airports in Kyiv - Boryspil International Airport (KPB) and Kyiv International Airport (Zhuliany) (IEV). These are connected with all the main European airports. Kherson International Airport (KHE) is connected with Kyiv, Istanbul, Katowice, Kraków and Vienna.

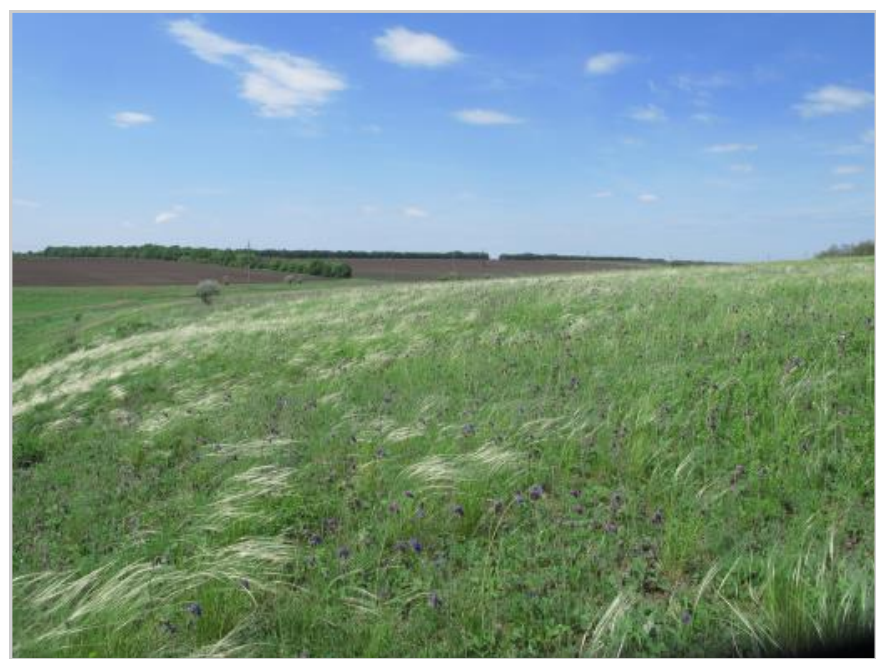

Fig. 12. Kil'chen River Valley. Photo: V. Maniuk.
We intend to leave from Kherson and start Field Workshop on Monday, $25^{\text {th }}$ May, at 09:00 a.m. FW will finish on Wednesday, $3^{\text {rd }}$ June, at approx. 16:00, in Kyiv city (airport Boryspil) or at approx. 20:00, in Kherson city. At the end of the expedition we can leave participants at the airport as well as in the city center in both cities. Please ensure that you organize your flight journeys so that they fit with this plan. Please book accommodation yourself if you need it on the night before or after the expedition (i.e. 24/25 May in Kherson or/and 03/04 June in Kyiv/Kherson). If you do not have a suitable connection or if you need help with booking hotels, you can contact Dariia Shyriaieva (darshyr@gmail.com) for assistance. For all who plan to reach Kherson by night train from Kyiv, we recommend to contact Dariia for organized purchase of tickets.

\section{References}

Beck, H.E., Zimmermann, N.E., McVicar, T.R., Vergopolan, N., Berg, A. \& Wood, E.F. 2018. Present and future Köppen-Geiger climate classification maps at 1 [l] $\mathrm{km}$ resolution. Scientific Data 5 : 180214. doi:10.1038/sdata.2018.214.

Bilyk, G.I., Osychniuk, V.V., Tkachenko, V.S. \& Barbarych, A.I. 1973. Roslynnist' URSR: stepy, kam'yanysti vidslonennia, pisky [Vegetation of UkrSSR: steppes, rocky outcrops, sands]. Naukova Dumka, Kyiv, UA. [in Ukrainian]

Biurrun, I., Burrascano, S., Dembicz, I., Guarino, R., Kapfer, J., Pielech, R., García-Mijangos, I., Wagner, V., Palpurina, S., (...) \& Dengler, J. 2019. GrassPlot v. 2.00 - first update on the database of multi-scale plant diversity in Palaearctic grasslands. Palaeartic Grasslands 44: 26-47.

Bohn, U., Gollub, G. \& Hettwer, C. 2000. Karte der natürlichen Vegetation Europas / Map of the Natural vegetation of Europe. Bundensamt für Naturschutz, Bonn, DE.

Dengler, J., Ruprecht, E., Szabó, A., Turtureanu, P. D., Beldean, M., Ugurlu, E., Pedashenko, H., Dolnik, C. \& Jones, A. 2009. EDGG cooperation on syntaxonomy and biodiversity of FestucoBrometea communities in Transylvania (Romania): Report and preliminary results. Bulletin of the Eurasian Dry Grassland Group 4: 13-19.

Dengler, J., Kuzemko, A. \& Yavorska, O. 2010. Impressions from the EDGG Research Expedition 2010 to Central Podolia (Ukraine). Bulletin of the European Dry Grassland Group 8: 15-16.

Dengler, J., Becker, T., Ruprecht, E., Szabó, A., Becker, U., Beldean, M., Biţă-Nicolae, C., Dolnik, C., Goia, I., (...) \& Uğurlu, E. 2012. Festuco-Brometea communities of the Transylvanian Plateau (Romania) - a preliminary overview on syntaxonomy, ecology, and biodiversity. Tuexenia 32: 319-359.

Dengler, J., Boch, S., Filibeck, G., Chiarucci, A., Dembicz, I., Guarino, R., Henneberg, B., Janišová, M., Marcenò, C., (...) \& Biurrun, I. 2016. Assessing plant diversity and composition in grasslands across spatial scales: the standardized EDGG sampling methodology. Bulletin of the Eurasian Grassland Group 32: 13-30.

Dengler, J., Wagner, V., Dembicz, I., García-Mijangos, I., Naqinezhad, A., Boch, S., Chiarucci, A., Conradi, T., Filibeck, G., (...) \& Biurrun, I. 2018. GrassPlot - a database of multi-scale plant diversity in Palaearctic grasslands. Phytocoenologia 48: 331-347.

Fick, S.E. \& Hijmans, R.J. 2017. Worldclim 2: New 1-km spatial resolution climate surfaces for global land areas. International Journal of Climatology 12: 4302-4315.

Filibeck, G., Cancellieri, L., Sperandii, M.G., Belonovskaya, E., Sobolev, N., Tsarevskaya, N., Becker, T., Berastegi, A., Bückle, C., (...) \& Biurrun, I. 2018. Biodiversity patterns of dry grasslands in 

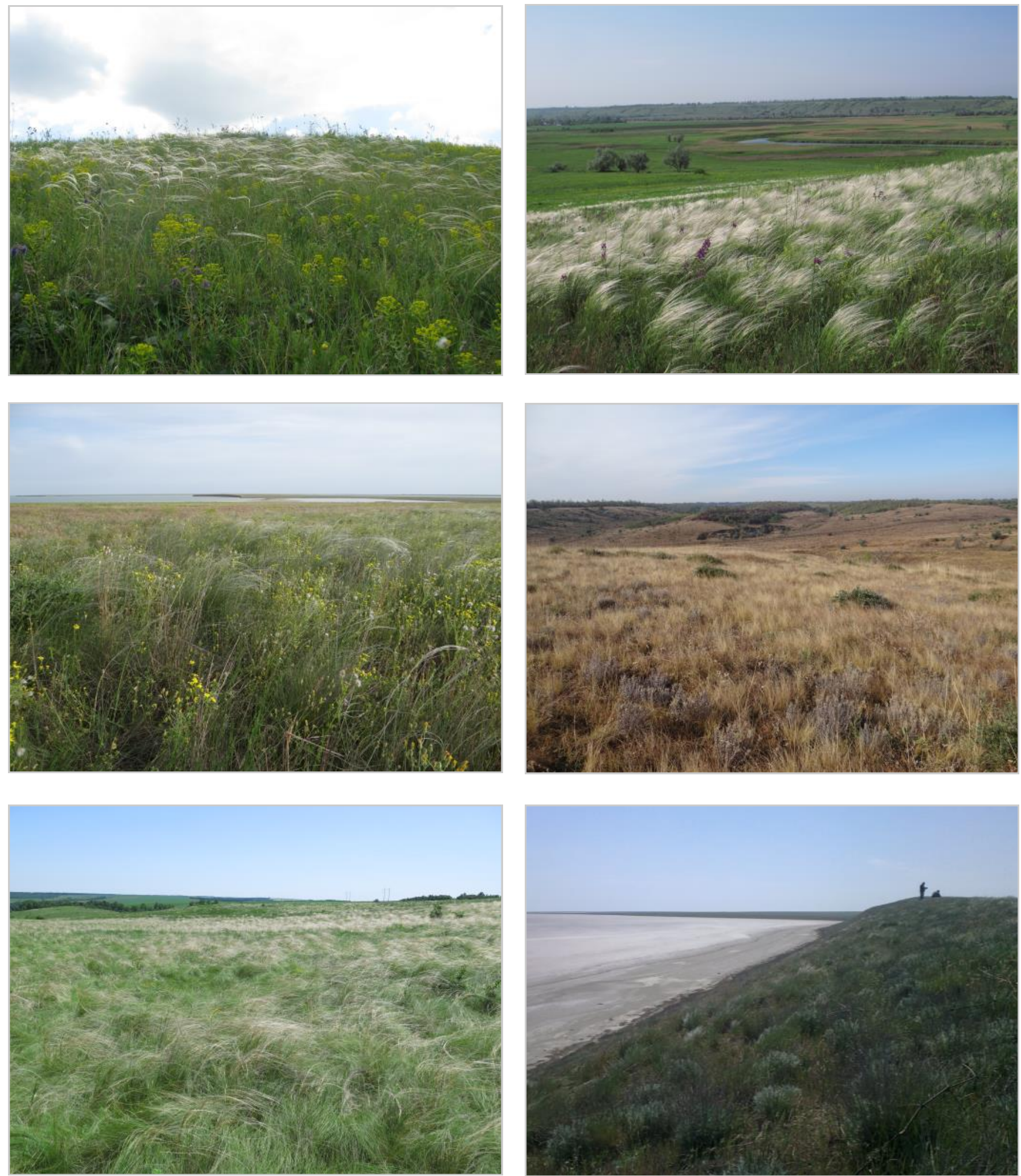

Fig. 13. Examples of dry grasslands in the study regions of the $14^{\text {th }}$ EDGG Field Workshop. From upper left to lower right: forb-bunchgrass steppe in Abazivka (Photo: D. Davydov) and Kil'chen River Valley (Photo: V. Maniuk), bunchgrass steppes on Churiuk Island and in Troitska Balka (Photos: V. Kolomiychuk), meadow steppes in Samara River Valley (Photo: V. Maniuk), desertified salt steppes on Kuyuk-Tuk Island (Photo: D. Vynokurov). 
Table 1. Preliminary itinerary of the $14^{\text {th }}$ EDGG Field Workshop in Ukrainian steppes along climatic gradients.

\begin{tabular}{|c|c|c|c|c|}
\hline Day & $\begin{array}{l}\text { Times } \\
\text { (approx.) }\end{array}$ & Journey & Dry grassland sites (preliminary) & Overnight \\
\hline \multirow[t]{2}{*}{25 May (Monday) } & 09.00 & \multirow{2}{*}{$\begin{array}{c}\text { Kherson - Syvash Lake - } \\
\text { Henichesk }\end{array}$} & $\begin{array}{l}\text { Morning: Meeting the group near the main train } \\
\text { station (Kherson) }\end{array}$ & \multirow[t]{2}{*}{ Henichesk } \\
\hline & 19.00 & & Afternoon: Churiuk Island and Kuyuk-Tuk Island & \\
\hline \multirow[b]{2}{*}{26 May (Tuesday) } & 08.00 & \multirow{2}{*}{$\begin{array}{l}\text { Henichesk - Syvashyk } \\
\text { Liman - Henichesk }\end{array}$} & Morning: Syvashyk Liman & \multirow[b]{2}{*}{ Henichesk } \\
\hline & 18.00 & & $\begin{array}{c}\text { Afternoon: Utliutsky Liman and Velykyi Utliuk } \\
\text { River Valley }\end{array}$ & \\
\hline \multirow{2}{*}{$\begin{array}{c}27 \text { May } \\
\text { (Wednesday) }\end{array}$} & 08.00 & \multirow{2}{*}{$\begin{array}{l}\text { Henichesk - Melitopol - } \\
\text { Zaporizhzhia }\end{array}$} & Morning: Tashhenak River Valley, Troitska Balka & \multirow{2}{*}{$\begin{array}{l}\text { Khortytsia Island } \\
\text { (Zaporizhzhia) }\end{array}$} \\
\hline & 19.30 & & Afternoon: Molochna River Valley & \\
\hline \multirow[t]{2}{*}{28 May (Thursday) } & 08.00 & \multirow[t]{2}{*}{$\begin{array}{l}\text { Zaporizhia - Step- } \\
\text { nohirsk - Zaporizhzhia }\end{array}$} & $\begin{array}{l}\text { Morning: steppe gulleys } \\
\text { in Dnipro River Valley }\end{array}$ & \multirow{2}{*}{$\begin{array}{l}\text { Khortytsia Island } \\
\text { (Zaporizhzhia) }\end{array}$} \\
\hline & 18.00 & & Afternoon: Khortytsia Island & \\
\hline \multirow{2}{*}{29 May (Friday) } & 08.00 & \multirow{2}{*}{$\begin{array}{l}\text { Zaporizhzhia - Vidrad- } \\
\text { ne - Dnipro }\end{array}$} & $\begin{array}{l}\text { Morning: steppe gulleys } \\
\text { in Dnipro River Valley }\end{array}$ & \multirow{2}{*}{ Dnipro } \\
\hline & 18.30 & & $\begin{array}{l}\text { Afternoon: regional landscape park "Dniprovi } \\
\text { Porohy" }\end{array}$ & \\
\hline \multirow{2}{*}{30 May (Saturday) } & 08.00 & \multirow{2}{*}{$\begin{array}{l}\text { Dnipro - Spaske - Sa- } \\
\text { mara river - Dnipro }\end{array}$} & Morning: Kil'chen River Valley & \multirow{2}{*}{ Dnipro } \\
\hline & 18.00 & & Afternoon: Samara River Valley & \\
\hline \multirow{2}{*}{31 May (Sunday) } & 08.00 & \multirow{2}{*}{$\begin{array}{l}\text { Dnipro - Nehvoroshcha } \\
\text { - Poltava }\end{array}$} & Morning: Kil'chen River Valley, Oril River Valley & \multirow{2}{*}{ Poltava } \\
\hline & 19.00 & & Afternoon: vicinity of Poltava town & \\
\hline \multirow[t]{2}{*}{1 June (Monday) } & 08.00 & \multirow[t]{2}{*}{$\begin{array}{l}\text { Poltava - Klymivka - } \\
\text { Stepove - Poltava }\end{array}$} & $\begin{array}{l}\text { Morning: Orchyk } \\
\text { River Valley }\end{array}$ & \multirow[t]{2}{*}{ Poltava } \\
\hline & 18.30 & & Afternoon: Berestova River Valley & \\
\hline \multirow{2}{*}{2 June (Tuesday) } & 08.00 & \multirow{2}{*}{$\begin{array}{l}\text { Poltava - Zin'kiv - Pol- } \\
\text { tava }\end{array}$} & Morning: vicinity of Zin'kiv town & \multirow{2}{*}{ Poltava } \\
\hline & 18.30 & & Afternoon: vicinity of Zin'kiv town & \\
\hline \multirow[t]{2}{*}{3 June (Wednesday) } & 08.00 & Poltava - Kyiv & $\begin{array}{l}\text { Morning: returning to Kyiv, stop for the sam- } \\
\text { pling in the flood plain of the Psel River }\end{array}$ & \multirow[t]{2}{*}{ Departure } \\
\hline & 15.30 & & Afternoon: arrival to Kyiv (Boryspil airport) & \\
\hline
\end{tabular}

the Central Apennines (Italy) along a precipitation gradient: experiences from the 10th EDGG Field Workshop. Bulletin of the Eurasian Grassland Group 36: 25-41.

Guijarro, J.A. 2019. climatol: Climate Tools (Series Homogenization and Derived Products). R package version 3.1.2. https://CRAN.R - project.org/package=climatol

Hurka, H., Friesen, N., Bernhardt, K.G., Neuffer, B., Smirnov, S.V., Shmakov, A.I. \& Blattner, F.R. 2019. The Eurasian steppe belt: Status quo, origin and evolutionary history. Turczaninowia 22 (3): 5-71.

Kolomiychuk, V. \& Vynokurov, D. 2016. Syntaxonomy of the Festuco-Brometea class vegetation of the Azov sea coastal zone. Hacquetia 15(2): 79-104.

Kolomiychuk, V.P., Onyshchenko, V.A. \& Peregrym, M.M. 2012. Vazhlyvi botanichni terytorii Pryazovia [Important plant areas of Azov sea region]. Alterpres, Kyiv, UA. [in Ukrainian]

Kostyliov, O.V., Ustymenko, P.M. \& Popovych, S.Y. 1994. Roslynnyi pokryv zakaznyka "Syvashyk" [Vegetation cover of the reserve "Syvashyk"]. Ukrainian Botanical Journal 51(5): 115-120. [in Ukrainian]
Kuzemko, A., Becker, T., Didukh, Y.P., Ardelean, I.A., Becker, U., Beldean, M., Dolnik, C., Jeschke, M., Naqinezhad, A., (...) \& Dengler, J. 2014. Dry grassland vegetation of Central Podolia (Ukraine) - a preliminary overview of its syntaxonomy, ecology and biodiversity. Tuexenia 34: 391-430.

Kuzemko, A., Steinbauer, M.J., Becker, T., Didukh, Y.P., Dolnik, C., Jeschke, M., Naqinezhad, A., Ugurlu, E., Vassilev, K. \& Dengler, J. 2016. Patterns and drivers of phytodiversity in steppe grasslands of Central Podolia (Ukraine). Biodiversity and Conservation 25: 2233-2250.

Magnes, M., Mayrhofer, H., Kirschner, P., Stöhr, O., Schwager, J., Dengler, J. \& Biurrun, I. 2018. Invitation and guide to the 11th EDGG Field Workshop: Grasslands of inneralpine dry valleys: part 1, Eastern Alps. Austria, 6-13 July 2018. Bulletin of the Eurasian Dry Grassland Group 36: 12-24.

Muhs, D.R. 2007. Loess deposits, origins and properties. In: Elias, S.A. (ed.) Encyclopedia of Quaternary science, pp. 1405-1418. Elsevier, Oxford, UK.

Pedashenko, H., Apostolova, I., Boch, S., Ganeva, A., Janišová, M., Sopotlieva, D., Todorova, S., Ünal, A., Vassilev, K., Velev, N. \& Dengler, J. 2013. Dry grasslands of NW Bulgarian mountains: 
first insights into diversity, ecology and syntaxonomy. Tuexenia 33: 309-346.

Polchaninova, N., García-Mijangos, I., Berastegi, A., Dengler, J. \& Biurrun, I. 2018. New data on the spider fauna (Araneae) of Navarre, Spain: results from the 7th EDGG Field Workshop. Arachnology Letters 56: 17-23.

Polyakova, M.A., Dembicz, I., Becker, T., Becker, U., Demina, O.N., Ermakov, N., Filibeck, G., Guarino, R., Janišová, M., (...) \& Dengler, J. 2016. Scale- and taxon-dependent patterns of plant diversity in steppes of Khakassia, South Siberia (Russia). Biodiversity and Conservation 25: 2251-2273.

Popov, V.P., Marynych, A.M. \& Lan'ko, A.I. (eds.). 1968. Fizikogeograficheskoye rayonirovaniye Ukrainskoy SSR [Physiographic zoning of UkrSSR]. Publishing house of Kyiv University, Kyiv, UA. [in Russian]

Turtureanu, P.D., Palpurina, S., Becker, T., Dolnik, C., Ruprecht, E., Sutcliffe, L.M.E., Szabó, A. \& Dengler, J. 2014. Scale- and taxon dependent biodiversity patterns of dry grassland vegetation in Transylvania (Romania). Agriculture, Ecosystems \& Environment 182: 15-24.

\section{Local organizers:}

Denys Vynokurov, Kyiv, Ukraine denys.vynokurov@ukr.net

Ivan Moysiyenko, Kherson, Ukraine ivan.moysiyenko@gmail.com

Dariia Shyriaieva, Kyiv, Ukraine darshyr@gmail.com

Alexander Khodosovtsev, Kherson, Ukraine Khodosovtsev@i.ua

EDGG Field Workshop Coordinators:

Iwona Dembicz,

Warsaw, Poland \& Wädenswil Switzerland

i.dembicz@gmail.com

Idoia Biurrun, Bilbao, Spain

idoia.biurrun@ehu.es

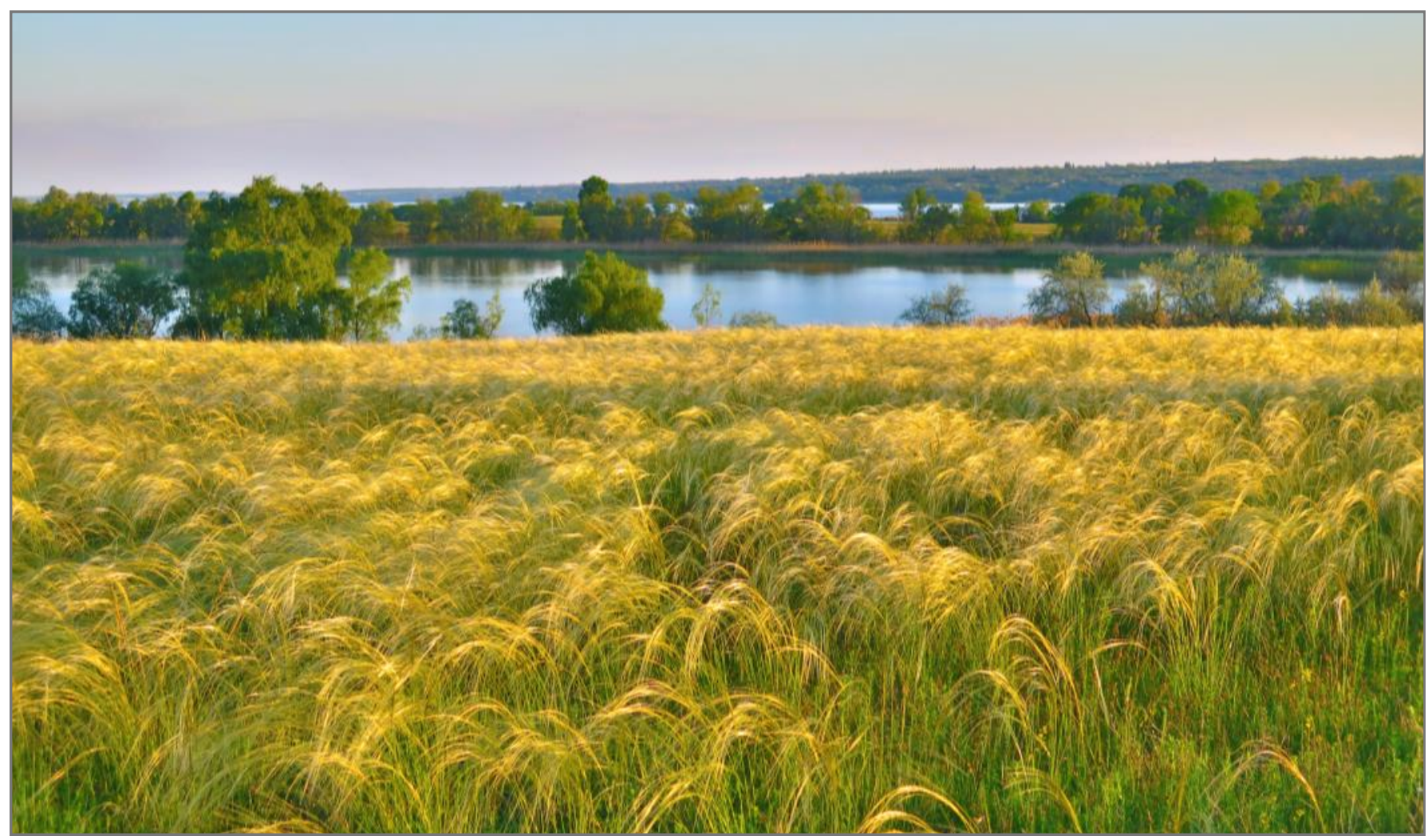

Fig. 14. Dry grasslands in "Dniprovi Porohy” Regional Landscape Park. Photo: V. Maniuk. 


\section{Post-conference report}

\section{$16^{\text {th }}$ Eurasian Grassland Conference (2019)}

\section{Graz, Austria and Maribor, Slovenia}

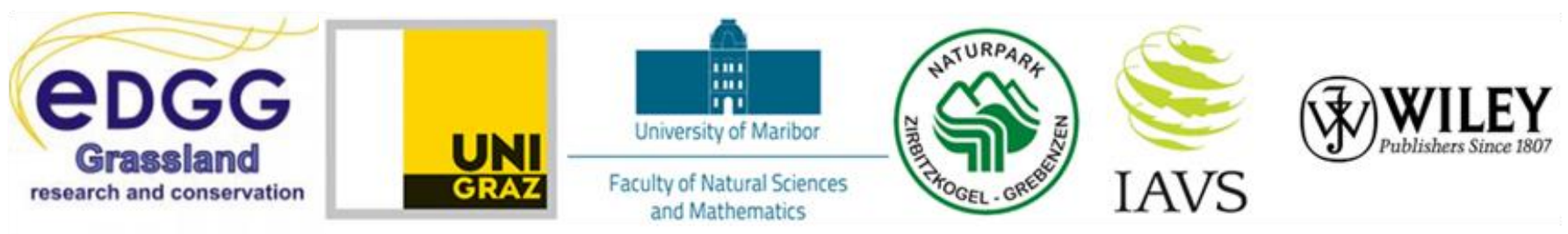

Martin Magnes $^{1^{*}}$, Sonja Škornik ${ }^{2}$, Nataša Pipenbaher ${ }^{2}$ and Didem Ambarlı ${ }^{3,4}$

${ }^{1}$ University of Graz, Institute of Biology, Department of Plant Sciences, Holteigasse 6, A-8010 Graz, Austria; martin.magnes@uni-graz.at

${ }^{2}$ University of Maribor, Faculty of Natural Sciences and Mathematics, Biology Department, Koroška cesta 160, Slovenia; sonja.skornik@um.si (S. Škornik), natasa.pipenbaher@um.si (N. Pipenbaher)
${ }^{3}$ Terrestrial Ecology Research Group, Department for Ecology and Ecosystem Management, Technical University of Munich, Hans-Carl-von-Carlowitz -Platz 2, D-85354 Freising, Germany; didem.ambarli@gmail.com

${ }^{4}$ Department of Agricultural Biotechnology, Faculty of Agricultural and Natural Sciences, Düzce University, 81620 Düzce, Turkey

*) Corresponding author martin.magnes@uni-graz.at

\section{Abstract}

The $16^{\text {th }}$ EGC took place jointly in Austria and Slovenia between $29^{\text {th }}$ May and $5^{\text {th }}$ June 2019. A total of 68 participants from 17 European countries were welcomed. In hall sessions, 27 oral ( 10 from young investigators) and 22 poster ( 9 from young investigators) contributions were presented. Three keynotes, Zsolt Molnár, Matej Vidrih and Wolfgang Willner, gave inspiring and informative plenary talks. Optional workshops were held on Natura 2000 biogeographical processes, scientific writing and bryophyte identification. A mid-conference excursion was taken to a "hay-milk region" in Steiermark and a three day post-conference excursion to Slovenia.

The main topic of this year's conference was to discuss the economic value of species-rich grasslands. The aim was to connect the biological and agronomical as well as sociological aspects of the grassland preservation. The conference brought those different disciplines related to grasslands together. Participants had the opportunity to hear studies and perspectives from different sides. It was concluded that both biology and agronomy need to learn more from each other to find ways of how this treasure of 6,000 years of grassland culture can survive.

\section{Introduction}

The $16^{\text {th }}$ Eurasian Grassland Conference "Species-rich grasslands in the Palaearctic - a treasure without economic value?" was held in in Graz, Austria with a post-conference excursion in Slovenia from 29 $9^{\text {th }}$ May to $5^{\text {th }}$ June 2019 (Magnes 2019). The conference was organized jointly by Martin Magnes, Institute of Biology, University of Graz as well as Nataša Pipenbaher and Sonja Škornik, Department of Biology of the University of Maribor, Slovenia and was supported by the University of Graz and the Nature Park Zirbitzkogel-Grebenzen. It took place in the Botanical Garden and in the halls of the Institute of Biology, Department of Plant Sciences of the University of Graz. The event was officially opened on $30^{\text {th }}$ May by the speech of the head of the Department of Plant Sciences of the University of Graz, Martin Grube.

\section{Keynote speakers and mid-conference excursion}

Three keynote speakers gave inspiring and informative plenary talks. The first one, shortly after the opening ceremony, was presented by Zsolt Molnár (Fig. 1, Traditional Ecological Knowledge Research Group at the MTA Centre for Ecological Research, Hungary) with the title "Maintenance of species-rich grasslands by traditional farmers: diversity, practice, knowledge, subsidies and future" where he showed the deep knowledge of grassland ecosystems of the local Hungarian Csángó in the Eastern Carpathians in Romania and how they could use it for devoloping sustainable management techniques. The second keynote lecture was given by Matej Vidrih (Fig. 2, Biotechnical Faculty, University of Ljubljana, Slovenia) on "Sustainable pasture management in Slovenia: balancing productivity and biodiversity" in the morning of the $31^{\text {st }}$ 


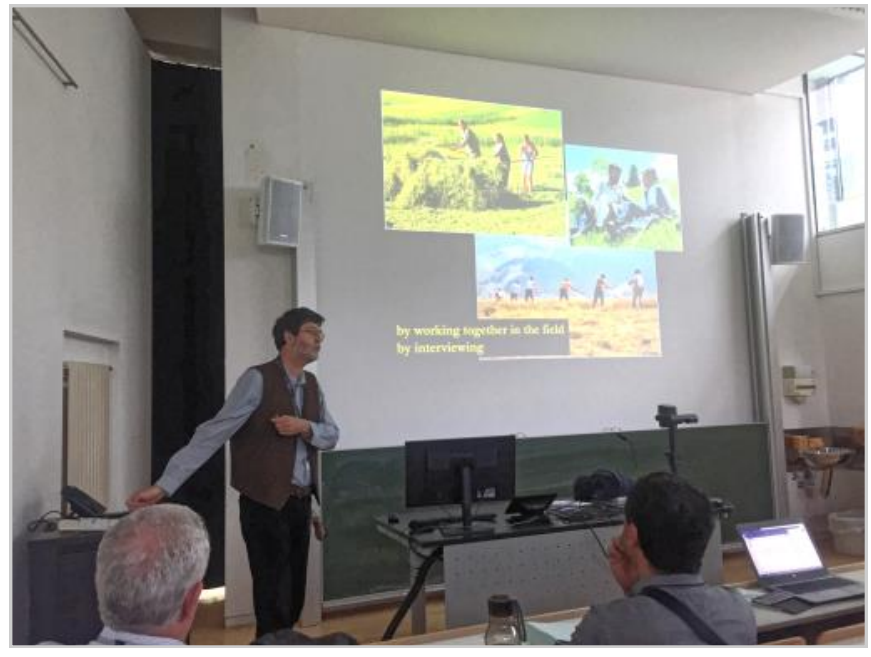

Fig. 1. Zsolt Molnár giving the $1^{\text {st }}$ keynote lecture on the $30^{\text {th }}$ of May. Photo: P. Sengl.

May. It was a perfect introduction to the mid-conference excursion, organized and guided by Martin Magnes, to Neumarkt in der Steiermark that showed us two farms that can use species rich grasslands for economic milk production. The 42 participants first visited the farm of the Sperl family in Mariahof were we saw the stable and the winter paddock following by a walk along their haymeadows and pastures. Magda Witzmann gave a short compilation of the results of her master thesis on the biodiversity of these pastures (Fig. 3). Our next and last target was the farm "Zeischgl" (Fig. 4), belonging to the Wölfl family who sells their home made products by direct marketing. After visiting the pastures, haymeadows, fields and some of the tourist facilities we were invited by the Naturpark Zirbitzkogel-Grebenzen for a tasting of the farm products.

The last keynote lecture was given by Wolfgang Willner (Fig. 5), VINCA - Vienna Institute for Nature Conservation and Analyses and University of Vienna, Department of Botany

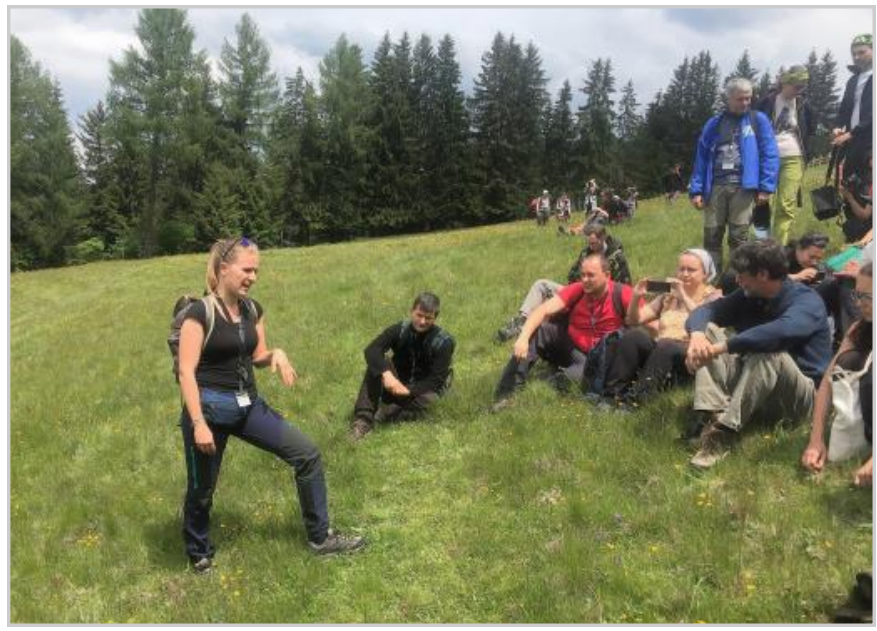

Fig. 3. Magda Witzmann on the pastures of the Sperl-farm during the mid-conference excursion. Photo: M. Magnes.

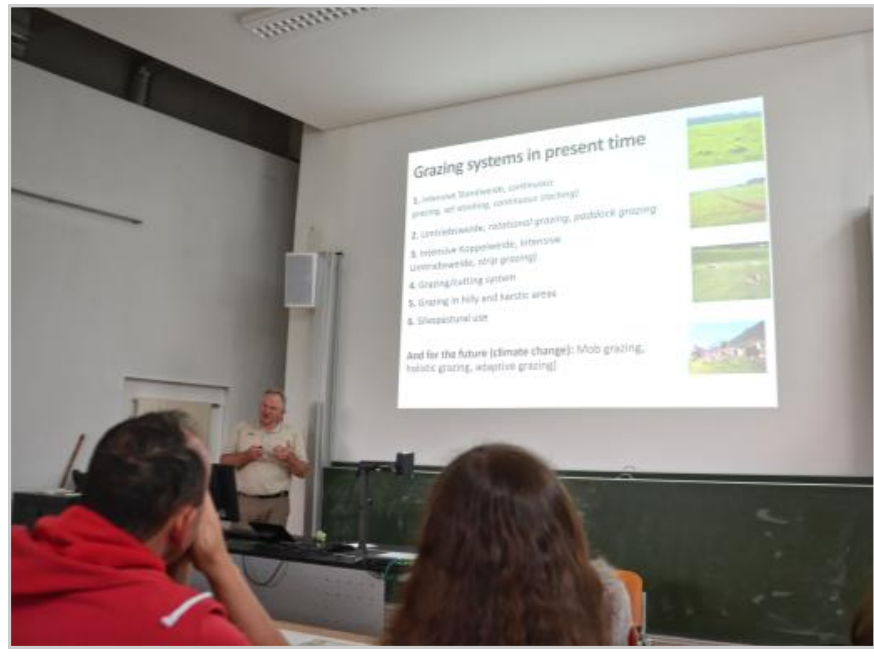

Fig. 2. Matej Vidrih presenting the $2^{\text {nd }}$ keynote lecture on the $31^{\text {th }}$ May. Photo: P. Sengl.

and Biodiversity Research, Austria) about "Semi-dry grasslands of Central and Eastern Europe - syntaxonomic and biogeographical aspects". In his lecture Wolfgang showed the high probability of the existence of "seminatural grasslands" during the whole Holocene in Europe.

Workshops and hall sessions A total of 68 participants from 17 countries were welcomed (Fig. 6). During hall sessions, 27 oral and 22 poster (Fig. 7) contributions were presented. Thanks to IAVS for supporting nine presenters with travel grants. Three optional workshops were held. A preconference workshop on Natura 2000 was led by Theo van der Sluis and Jan Sliva, 15 participants attended. After an introduction into the Biogeograpical Process (BGP) and the EU habitat plan for European semi-natural dry grasslands (code 6120) as well as European dry heaths (code 4030) by Theo, Jan showed some current Life-supported grassland projects and best practise examples. Working in small groups, the participants discussed (Fig. 8): 1. What are the

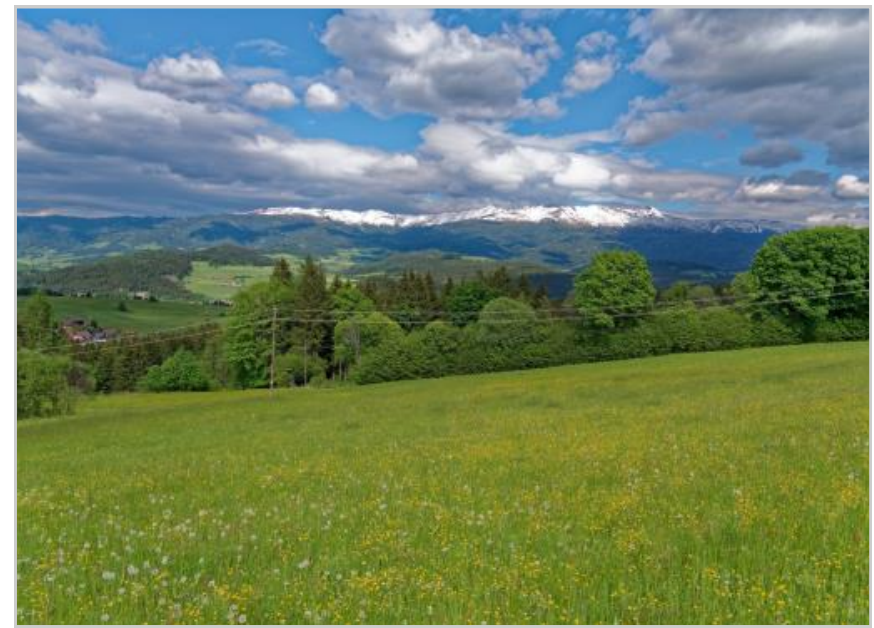

Fig. 4. Hay meadows of the farm Zeischgl, in the background the Zirbitzkogel. Photo: M. Magnes. 


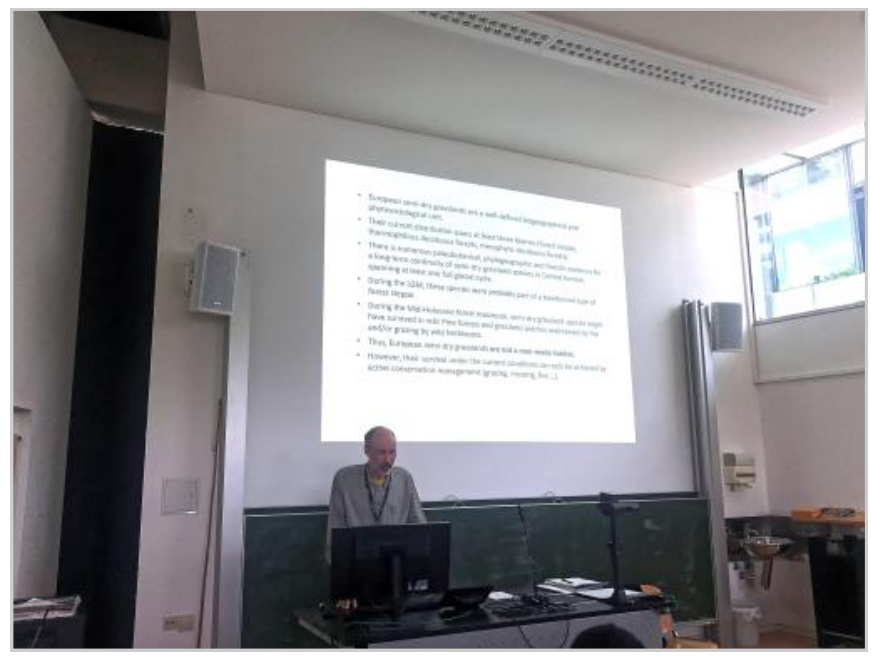

Fig. 5. Wolfgang Willner giving the $3^{\text {rd }}$ keynote lecture on the $1^{\text {st }}$ June. Photo: M. Magnes.

values delivered by grasslands? 2. How do farmers use and manage species rich grasslands? 3 . What are best practices for grassland management? 4. What are important socioeconomic conditions to conserve these grasslands? After the presentation of the results, Theo moderated a discussion, that showed that a majority thinks that a somehow economical use of these grasslands would be the most important aspect for their preservation.

The second workshop, on the topic of scientific writing, was organized and led by Jürgen Dengler on the $30^{\text {th }}$ May, after the poster sessions, and was attended by 10 participants. The participants learnt key points in clear and concise scientific writing.

Parallel to the already mentioned mid-conference-excursion on the $31^{\text {st }}$ May, Christian Berg led a bryophyte identification field-workshop (Fig. 9) where seven participants received detailed guidelines, learnt the collecting of bryophyte specimens, key features for their identification and got familiar with common species in cities and grasslands.

\section{Post conference excursion}

The post-conference workshop of this year's EGC was organized by Sonja Škornik and Nataša Pipenbaher from the University of Maribor. The excursion took place in Slovenia between $2^{\text {nd }}$ and $5^{\text {th }}$ June. In addition to the organisers, Mitja Kaligarič, Igor Paušič, Branko Bakan, Matej Vidrih and Stanka Dešnik were our excursion guides. A total of 25 participants joined the excursion and observed the diversity of the Goričko Landscape Park (Fig. 10), which forms one part of the Trilateral Park extending across Austria, Hungary and Slovenia. Goričko is a well-preserved example of typical and traditional Central-European agricultural landscape with a mosaic of fields, grasslands, orchards, vineyards, hedges and forest. The next morning the participants visited the Šturmovci Landscape Park (Fig. 11), were they could marvel at semi-dry alluvial hay meadows - the traditional management left some trees to preserve the hay from being washed away by summer floods of the near Drava river.

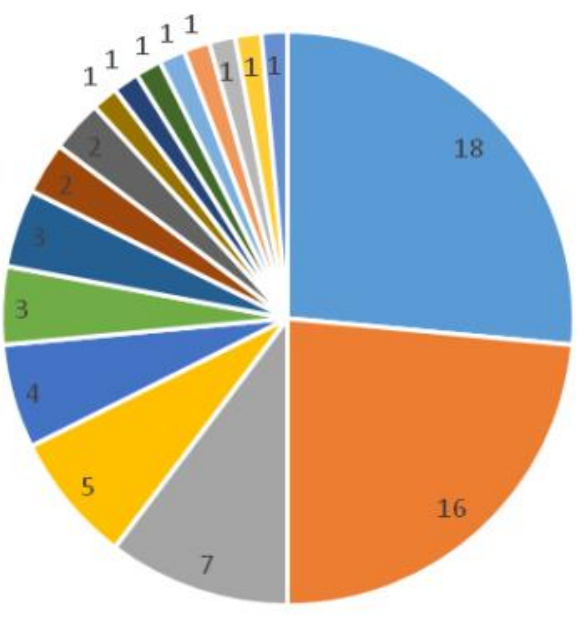

$\begin{array}{ll}\text { - Austria } & \text { n Hungary } \\ \text { - Italy } & \text { n Slovakia } \\ \text { - Spain } & \text { - Belgium } \\ \text { - Latvia } & \text { - Sithuania } \\ \text { - Switzerland } & \end{array}$

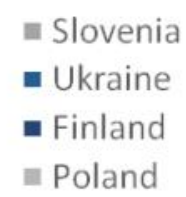

m Russian Federation

- Romania

- Germany

in Portugal

Fig. 6. Number of participants from different countries. 


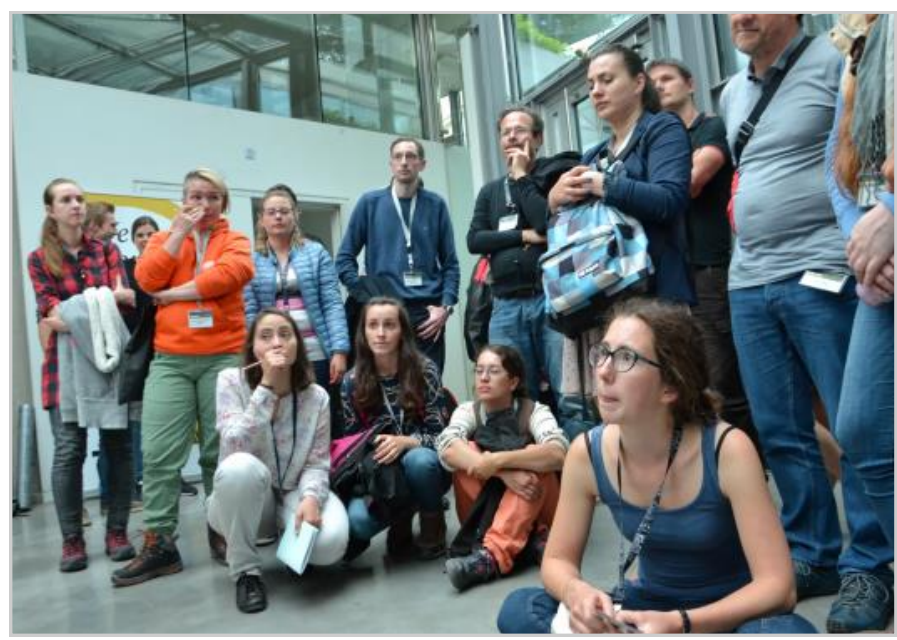

Fig. 7. Poster session. Photo: P. Sengl.

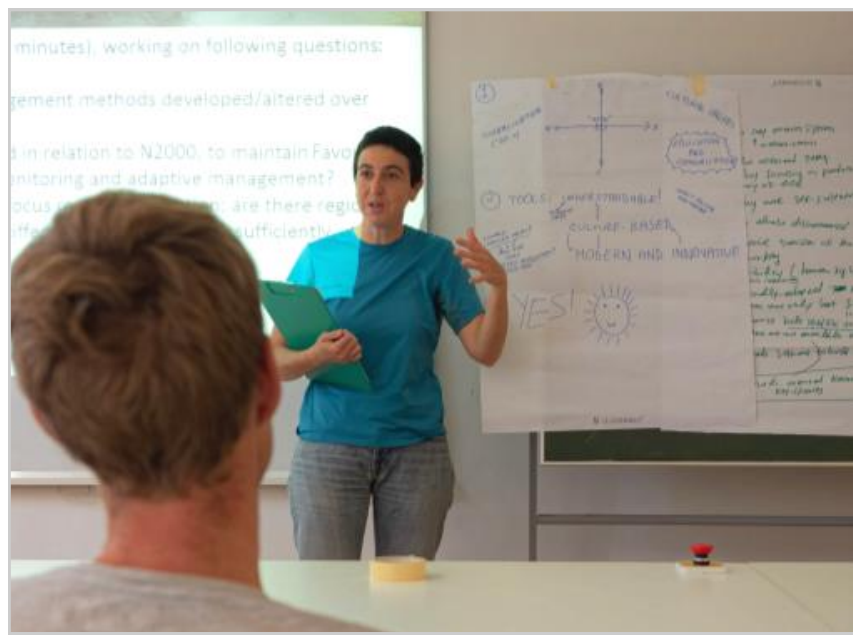

Fig. 8. Natura 2000 workshop, Luciana Carotenuto presenting the ideas of her group. Photo: M. Magnes.
Later they visited the Haloze region (Fig. 12), which has the highest density of "orchids-rich meadows" (Bromion erecti, ass. Onobrychido viciifoliae-Brometum) in Slovenia (approx. $25 \%$ of non-forest land), bearing fantastic orchid habitats (Fig. 13). The third day took participants to the Slovenian Northern Adriatic karst zone, which represents the northwesternmost branch of the Dinaric mountain range, extending along the Eastern Adriatic (Fig. 14).

\section{Social events and young investigator prizes}

The participants enjoyed a grassland party on the evening of the $31^{\text {st }}$ May, savoured typical Styrian food, wine (including examples from the Slovenian Stajerska), a special brewed " $16^{\text {th }}$ EDGG conference beer" and some music performances from regional artists in the nice buildings of the green houses of the Botanical Garden. On the last day, the EDGG general assembly was held where chairs informed participants about past, current and future activities and received participants' valuable opinions. Finally, six researchers under the age of 35 received Young Investigator Prizes for outstanding talks or posters (Fig. 15). We congratulate Réka Kiss ( $1^{\text {st }}$ prize talk), Peter Kozel $\left(2^{\text {nd }}\right.$ prize talk), Laura Godó ( $3^{\text {rd }}$ prize talk), Iris Moeneclaey $\left(1^{\text {st }}\right.$ prize poster), Katalin Lukács ( $2^{\text {nd }}$ prize poster) and Maik Preßnitz ( $3^{\text {rd }}$ prize poster).

\section{Acknowledgements}

We thank our keynote speakers, tutors and excursion guides for sharing their expertise with us. We also thank our student helpers for their help during the conference days.

\section{Reference}

Magnes, M. (ed.) 2019. $16^{\text {th }}$ Eurasian Grassland Conference (EGC) (29 May-5 June 2019): Species-rich grasslands in the Palaearctic-a treasure without economic value? (Program and Abstracts). Fritschiana 92: 68 pp. pdf

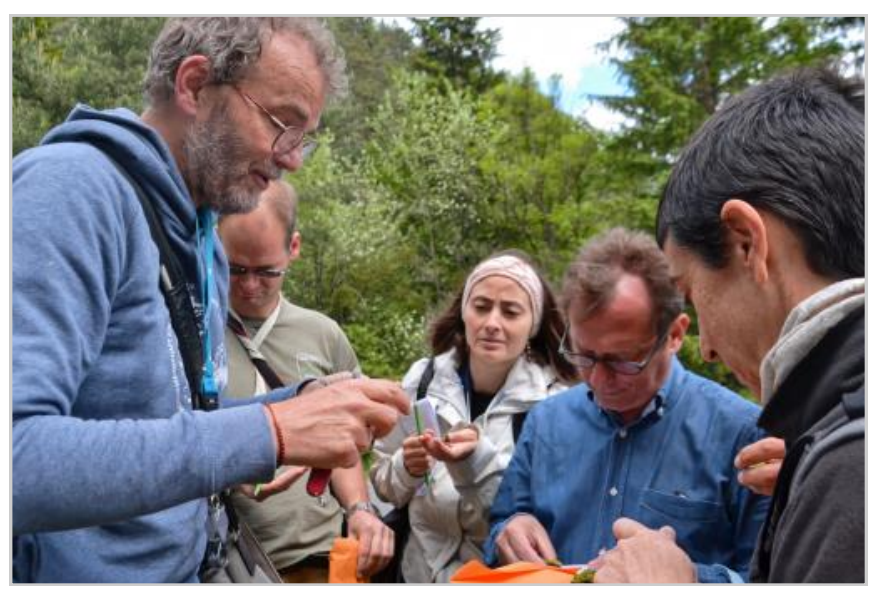

Fig. 9. Christian Berg explaining field determination of bryophytes. Photo: P. Sengl.

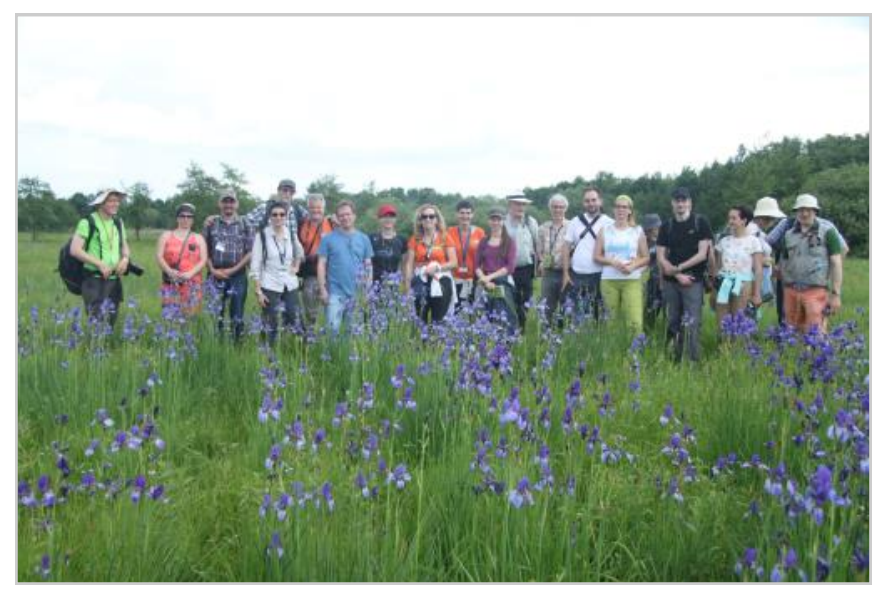

Fig. 10. First day of the post-conference excursion in the Goričko Landscape Park. Photo: N. Pipenbaher. 


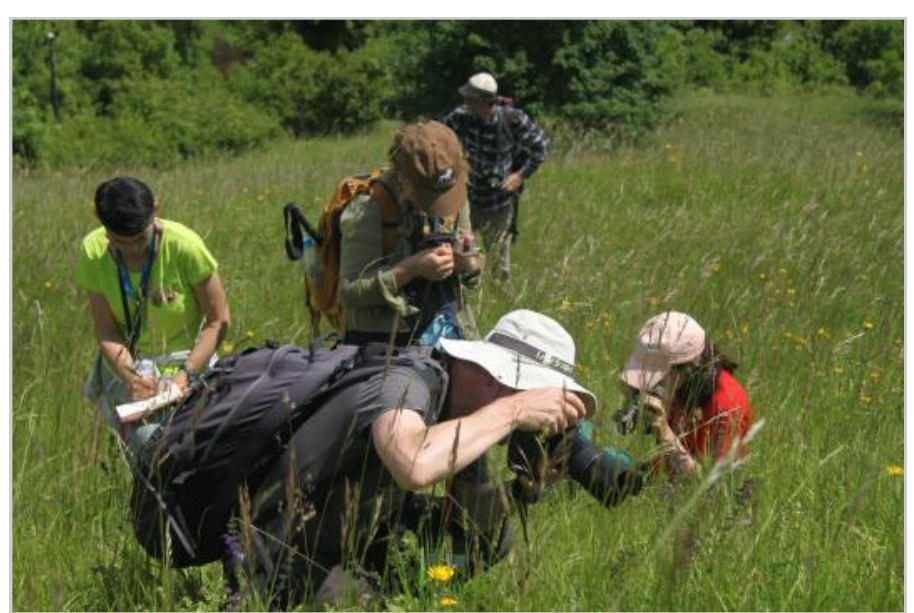

Fig. 11. Second day of the post-conference excursion in Šturmovci Landscape Park. Photo: N. Pipenbaher.

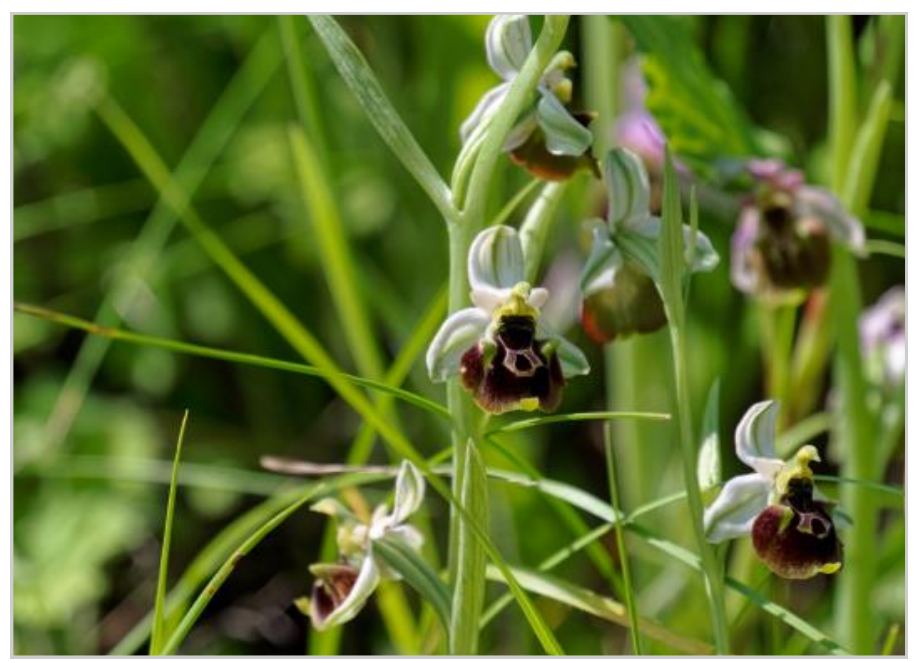

Fig. 13. Ophrys holosericea in the Haloze region. Photo: M. Magnes.

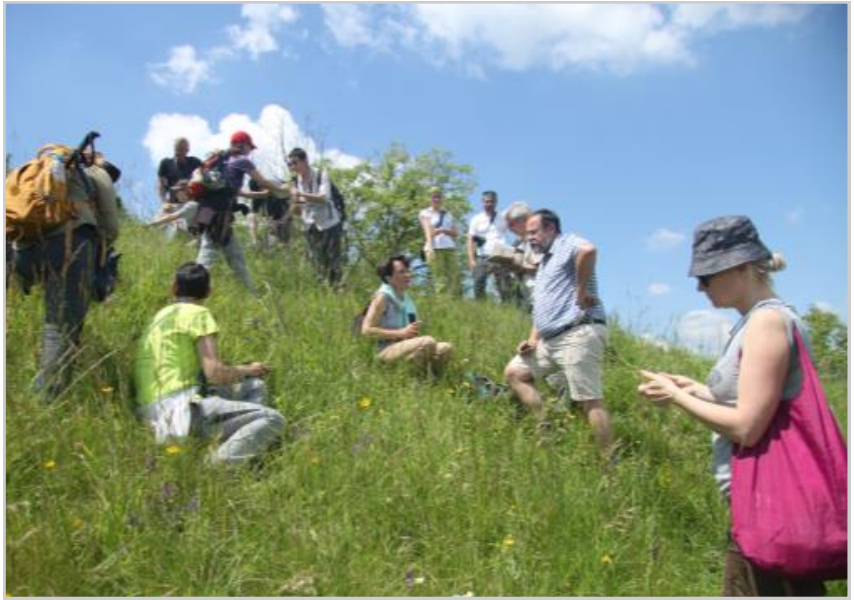

Fig. 12. Second day of the post-conference excursion in the Haloze region. Photo: N. Pipenbaher.

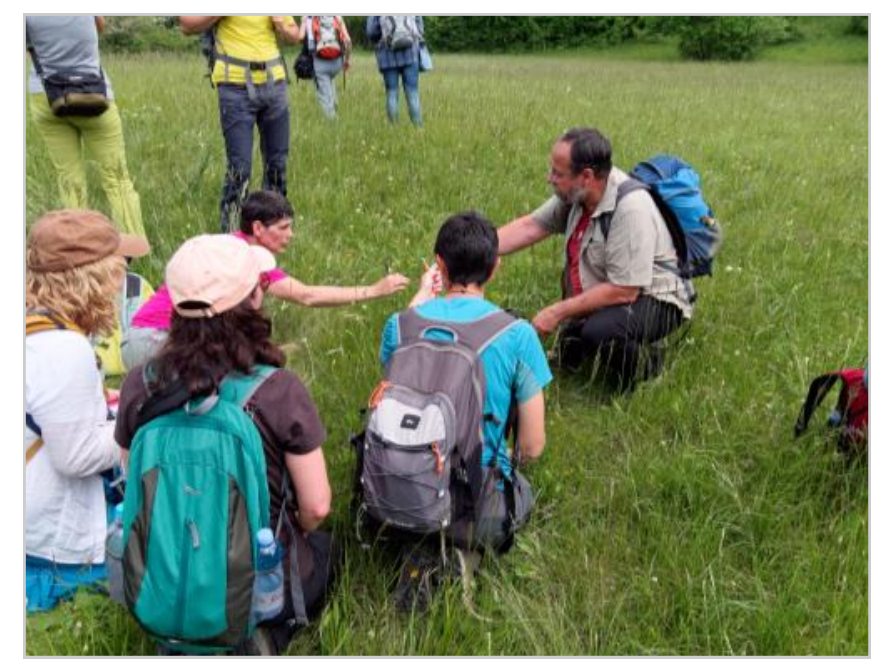

Fig. 14. The third day of the post-conference excursion in the Ćićarija, Mitja Kaligarič explaining details of a hay meadow. Photo: M. Magnes.

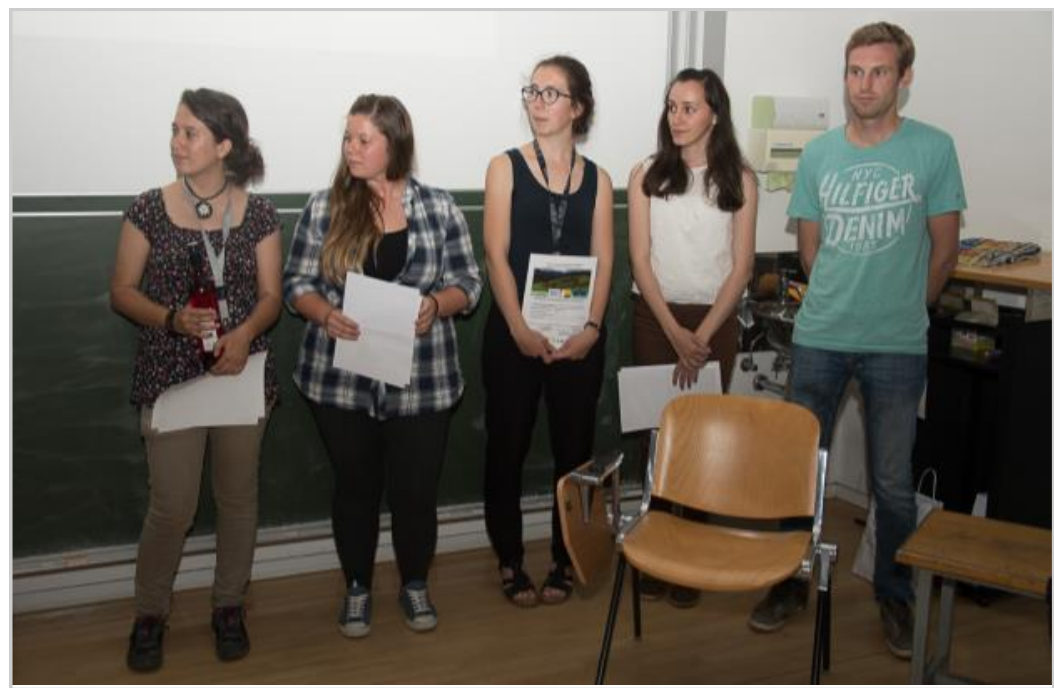

Fig. 15. The proud winners of the YI competition. Photo: J. Dengler. 


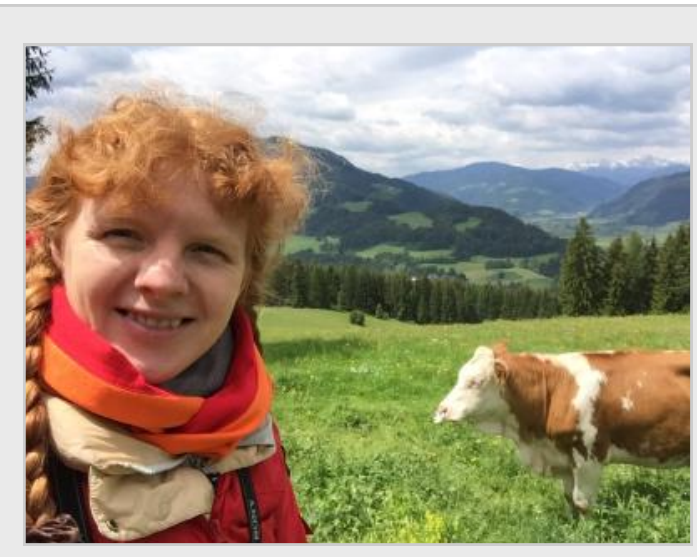

\section{Anna Komarova, Russian Federation}

Dear colleagues!

I'm very grateful for the chance to participate in the 16th EDGG conference in Graz, Austria. This was my first EDGG conference, and I was really impressed by the very friendly and hearty atmosphere! At the same time the atmosphere was really productive and inspiring for very intensive work.

The topic of the conference - Species-rich grasslands in the Palaearctic - a treasure without economic value? - was rather new for me. It complements our research, because in Russia we investigate grasslands on abandoned land the only type of place where we have Molinia meadow, for example. I was very pleased to present two reports covering our work. One of them, concerning two microsites, was presented first. Therefore, the questions and following discussion provided a great step forward for this research. In addition, the discussions and sessions at the conference made me realise that succession on abandoned lands (in our case) not only increases species richness, but also results in a decrease in the number of syntaxa.

I would like to say Thank you to Jürgen Dengler for the very useful Paper Writing Workshop. In spite of the very late time of the workshop, the content was very clear. My only suggestion for the conference would be to have more workshops or training sessions.

I also like the conference hosting. The botanical garden was really amazing! Honestly, I'm sure that the meditative walking through the collection redounded to advantage of assimilation and reinterpretation of the new information:) And I like Graz - the small quiet town with the aura of ancient European settlement. At the same time, the logistics were very handy and comfortable.

Of course, I really enjoyed the field trip! It's difficult to imagine seeing traditional agriculture and (semi-)natural landscapes at the same time! And - again - I appreciated the atmosphere of the field trip. Due to a lot of comments and consultation, I've learned a lot about Central Europe's flora and vegetation.

So thanks a lot to IAVS and EDGG for supporting of my participation and all conference attendees for a very productive and inspiring time! I'm sure this is not the last EDGG conference I attend, and hope to be part of a Big Grassland Community! I send the warmest wishes to all of you from cold Russia!

\section{Vadim Prokhorov, Russian Federation}

The conference in Graz was my first experience in participating in EDGG events. Prior to this, I only participated in IAVS symposia and EVS workshops. I was very happy to meet new people and see familiar faces. The venue impressed me a lot, the city of Graz is very beautiful with many big old parks and historical places. I really liked the University botanical garden where the conference was held, with a large collection of plants in greenhouses and arboretum. I would like to thank the Executive Committee of EDGG for financial support and the opportunity to participate in the 16th Eurasian Grassland Conference. The conference program was very

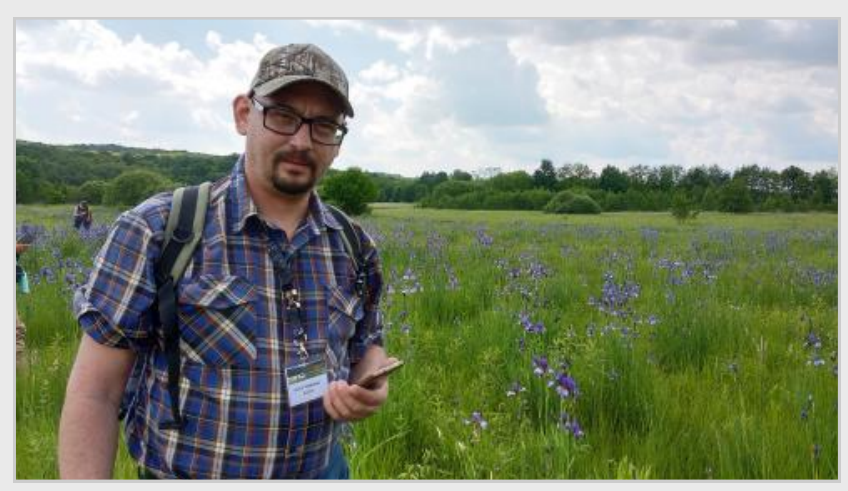
interesting and useful for me. It was a nice place to present the part of our work dedicated to distribution modeling of different plant communities. It was possible for me to communicate with many researchers from different countries and we found common topics for discussion. All presentations from participants were very interesting for me, especially the keynote talks, which helped me gain further understanding about many areas of work and new trends in the study of grasslands by European researchers.

However, the field excursions made the greatest impression on me. In a short time, it was possible to see a huge variety of natural habitats, from high alpine meadows to the Mediterranean coast. We traveled all over Slovenia and saw how grasslands are used and protected in different places.

As a flora specialist, I was extremely interested in seeing and photographing new plant species for me in their natural environment during the excursions.

Many thanks to everyone who participated in the preparation and conduct of the conference and excursions, and for excellent communication with us before our arrival. These are professional and enthusiastic people. I am looking forward to the next EDGG events! 


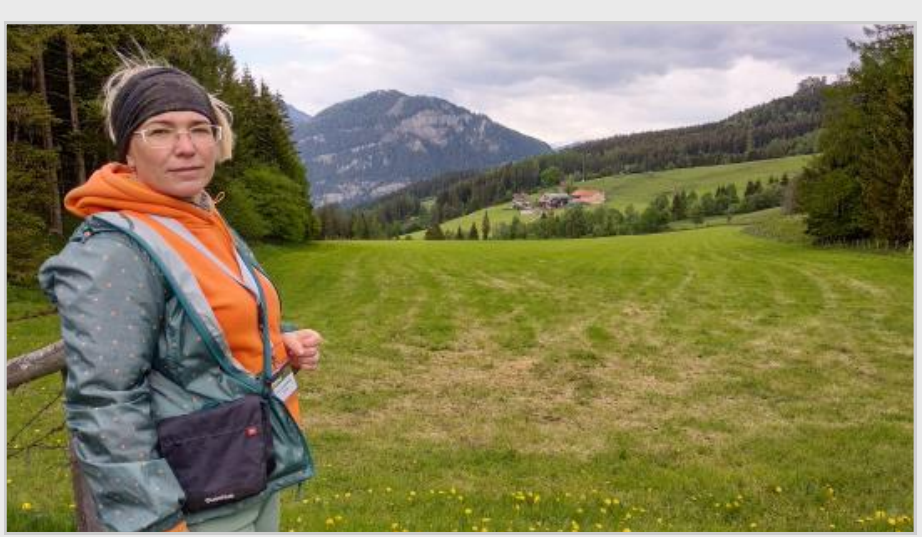

vation and restoration in the Palaearctic realm.

I want to say a big thank you to the organizers of the conference for the careful selection of key speakers; all of them were extremely interesting and professionally useful.

The post-conference tour was just awesome! It opened Slovenia to me, so small and so beautiful. I took a large number of photos in order to use them in the future to prepare lectures for students (different types of land use, unique types of communities, amazing Karst plateau). I want to thank the organizers for the great conference and I am looking forward to the next EGC and other EDGG events!

\section{Natalia Dulepova, Russian Federation}

I am very thankful to the EDGG and IAVS grant committee for the travel support and the opportunity to participate in the 16th Eurasian Grassland Conference (EGC) in Graz (Austria). The EGC 2019 was the first EDGG conference attended. I have never felt such sensitive support at a conference. There was a helpful and generally relaxed working attitude all at the same time. The selected city of Graz for the conference was ideal - a remote, comfortable, beautiful and green town. I enjoyed all presentations from keynote speakers, which gave me chance to have a broad-scale view on current international challenges and tendencies of different research in grasslands. The mid-conference excursion in the Neumarkt in Styria was very exciting and informative for me. It was fascinating to learn and to see how management, management changes and abandonment have shaped the appearance and plant species composition of these grasslands. Wolfgang Willner's lecture devoted to the semi-dry grasslands of Central and Eastern Europe was especially valuable to me. This knowledge is relevant to me, as I take part in common projects with our Siberian colleagues devoted to diversity and syntaxonomy of steppes from Ural to TransBaicalia. One of the most significant and very useful parts of the conference for me was the scientific writing workshop led by Jürgen Dengler. Thank you for the detailed analysis of the article, answers to the questions and recommended literature. I thank the organizers of the post-conference excursion to Slovenia. This allowed me to expand my knowledge, to see places unforgettable in beauty.

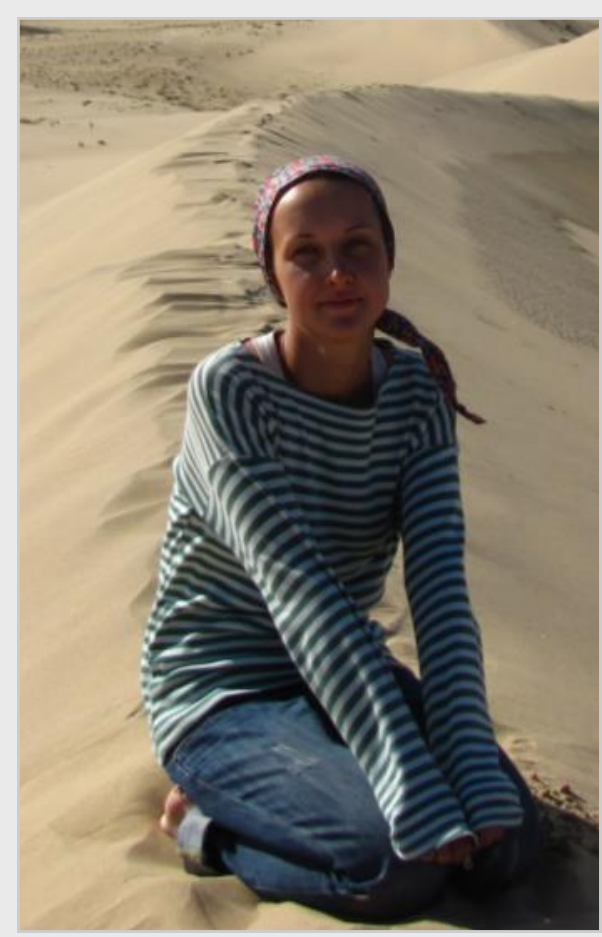




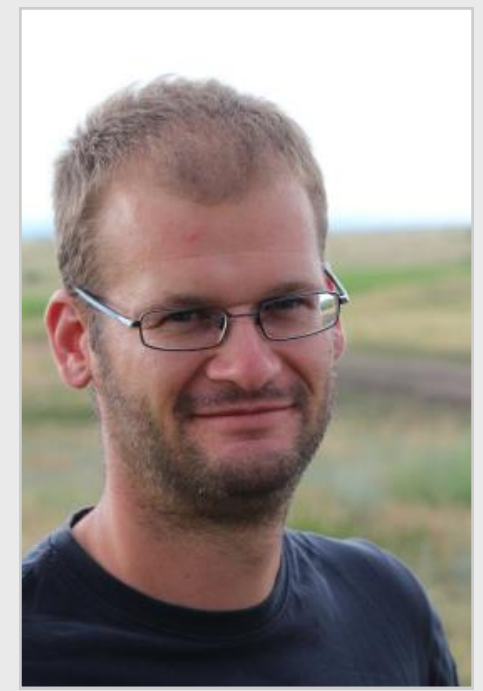

\section{Philipp Sengl, Austria}

The 16th Eurasian Grassland Conference was especially exciting for me because it took place in the region where I live (Styria, South-East Austria), introducing the participants to some of the most exciting places of Austria and - during the post-conference excursion - to Slovenia. With my colleagues I contributed to the scientific program with one poster and one oral presentation. While the poster, presented by my colleague Lisa Bernhard (University of Graz), dealt with germination properties of several dry grassland species, the oral presentation gave a preview of a new research topic: using habitat suitability models for pre-selecting most promising sites for restoration measures. The latter was presented by Patrick Schwager (University of Graz). One of the highlights for me was participating in the bryophyte course, during the mid-conference excursions. My former doctorate supervisor, Christian Berg, took us to a low to mid mountain range (640-960 $\mathrm{m}$ a.s.I.) in the vicinity of Graz (Semriach) und gave us some insight in the diversity of grassland bryophytes (Fig. 1). All in all, we exceeded the excursion target by far and collected more than 40 species, although we found time for a coffee and cake break too. Due to his enthusiasm in the field (Fig. 2), Christian was easily able to arouse our interest in this exciting field of botany. Traditionally, the 'grassland parties' are the main social events of the EGCs and are highly valued by the participants. Besides scientific interchange or design of common studies, it's the place to gain new friends in the scientific community. Additionally, during the grassland party in Graz a new tradition was founded - the auction of grasslandrelated artifacts. In my case, I was extraordinarily happy to purchase a traditional Romanian shepherd's crook (Fig. 3) made of European cornel (Cornus mas) which was provided by courtesy of Zsolt Molnár. Additionally, Zsolt showed me how to use it as a seat in the field... it's more comfortable than one might expect! So, by purchasing the shepherds crook, the IAVS grant was partly reinvested to support the Eurasian Dry Grassland Group and will persistently remind me of the wonderful conference in Graz.
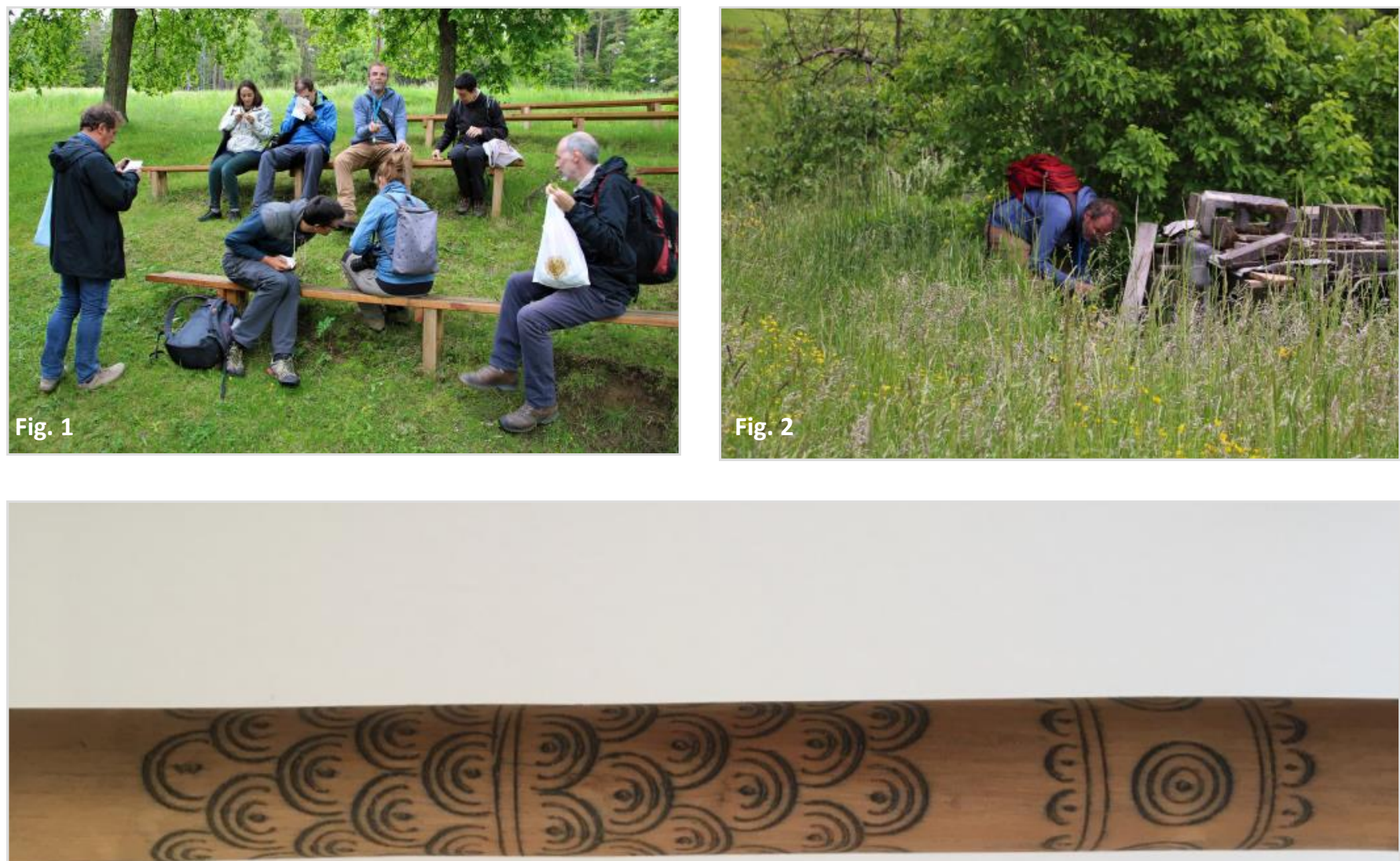

Fig. 3 


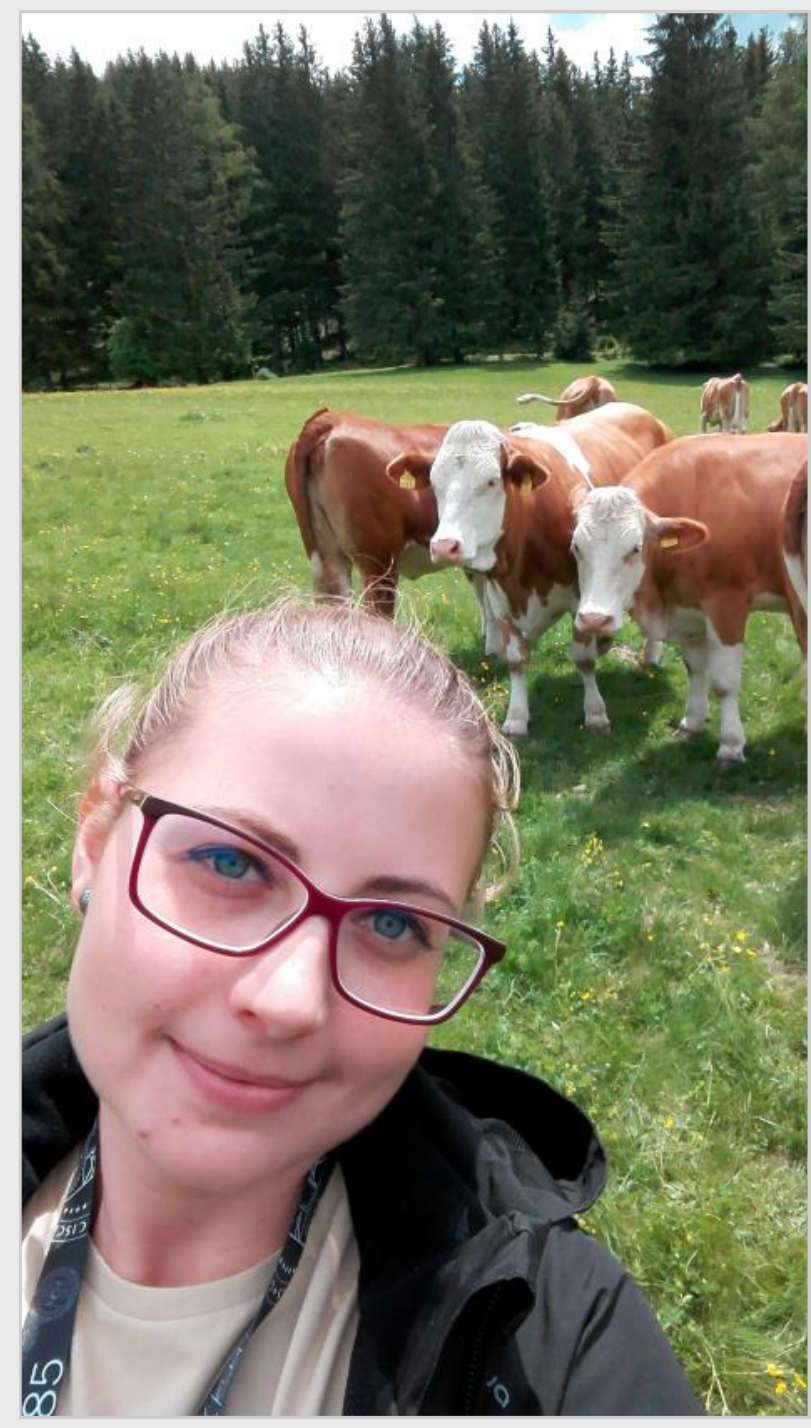

Edina Tóth, Hungary

This year's 16th Eurasian Grassland Conference well-explored the issues and experiences of dry grasslands from many different perspectives. The conference was organized around four sessions, where all those interested found the most appropriate lecture and poster for their field of interest. I am grateful that I managed to get to the conference with the help of the travel grant, and after my first EGC conference in 2016 I was able to present our Hungarian study on the effects of cattle grazing, in which I tried to draw attention to the importance of grassland-type management. My presentation was given in section 2, where we were able to present our national experiences with lawns together with many Hungarian colleagues. For me, the two major presentations of the conference were Zsolt Molnár's plenary presentation and his presentation in section 3 , where we could see how important it is to observe in detail the traditional lawn practice, the ancient relationship between people and nature and the acquisition of traditional knowledge that for example the local farmers of Gyimes and the shepherds of Hortobágy know and practice even today. But through several lectures, we could get an overview of the lawn and lawn management practices of the country organizing the conference, Austria. In the poster section, more than 20 posters were presented by the authors, which proved to be a good opportunity for young researchers to introduce themselves and the mood of the public performance. In my opinion, we have heard good poster presentations and interesting results have been shared.

The mid-conference excursion was also a good day and lively day during which we visited farms in Neumark / Steiermark as planned, but only two hay milk farms and surroundings: a hay milk farm of Sperl family in Mariahof and a hay milk farm: Farm Wölfl (Buschenschank Zeischgl). During the first bus stop we went to extensive grazing grasslands, which were very species rich and spectacular, with many interesting plant species such as Persicaria bistorta, Clematis alpina, Dactylorhiza sambucina, Valeriana tripteris, Campanula and Primula species. At our second stop, we were surrounded by a hay milk farm- Farm Wölfl. The farm is very old, has been a family of owners for several generations. They were engaged in the production of butter and cheese, from which we could get tasty samples at the end of the trip. The grasslands here are more heavily loaded by grazing, as they are grazing cattle in the surrounding lawns for the production of butter and milk. The mowing of mowed grasslands is the source of winter feeding for animals. In this region, this is a form of farming and livelihood. The produced dairy products are sold to local, nearby restaurants, where organic products are becoming more and more popular. During the excursion around the farm, there were also high numbers of species, such as: Persicaria bistorta, Pimpinella major, Avenula pubescens, Geum rivale, Dactylorhiza majalis, Pinguicula vulgaris. After the excursions, we could take part in the high-quality grassland party. All in all, we were able to listen to presentations from a number of perspectives and see the posters, and we also got an insight into the operation of the hay milk farms. The conference was also useful for me, and I have try to use the knowledge gained during the conference in our research on grasslands and cattle grazing. Thanks again for the travel grant. 


\section{Tatyana Gavrilova, Russian Federation}

EDGG events allow vegetation scientists from different countries to share the results of their work as well as to get new ideas and inspiration for future research. Thus, I am very grateful to the EDGG and IAVS grant committee for the travel support and the opportunity to participate in the $16^{\text {th }}$ Eurasian Grassland Conference in Graz, Austria.

This was my first EDGG conference as well as my first international conference; hence, I was particularly excited to participate in it. I was fascinated by the opportunity to meet people whose scientific articles I have read for my research. I was pleasantly surprised by the atmosphere of EGC 2019, both relaxed and professional. My aim of participating in the conference was to present the first results of studying functional traits of leaves at abandoned and managed sites in Central Forest Reserve, NW Russia, as a poster. I had a wonderful opportunity to discuss the results of my work and received valuable feedback. I hope that it will help me to improve the quality of my future research. Furthermore, participating in the conference allowed me to improve my communication skills and to learn more about current methods and approaches of studying grasslands.

I was especially interested in a workshop on scientific writing guided by Jürgen Dengler. I am particularly grateful to Jürgen and the participants of the workshop for valuable advice concerning various aspects of scientific writing such as structuring the article and its parts, choosing the best title and targeting the journal most suitable for the article.

I would like to thank local organizers of EGC 2019 for a delightful social dinner with traditional Styrian cuisine and music as well as for the mid-conference excursion to Neumarkt. It was an excellent opportunity to learn more about EU practices of grassland management and organic farming as well as to enjoy the magnificent landscapes of the Alps. Thank you all for a wonderful conference!

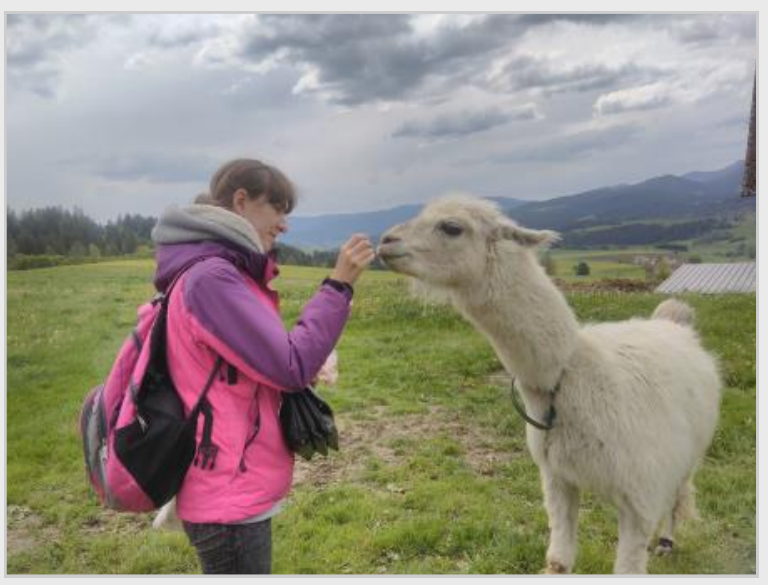

Olha Yaroshko, Ukraine

I am thankful to the EDGG and IAVS grant committee for the financial support they gave me to participate in the 16th Eurasian Grassland Conference 2019 in Graz.

It is the first time I have participate in an EGG conference, and the first large-scale conference in my life. The conference program was very eventful. There were a lot of interesting poster presentations.

During the conference, I obtained new knowledge and practical skills in identifying plants during the mid-conference excursion to the mountains. I am glad that I met new people, I was very pleased to talk with Didem, Idoia, Martin and Iwona, I will remember them for a long time. I also met several young scientists, most of all, I remember Iris from Belgium and I had the opportunity to share my experience with her, her $\mathrm{PhD}$ work is also related to the introduction of plants in vitro culture and the propagation of plants. Also, unexpectedly for me, I met participants from Ukraine, with whom I was previously familiar (I did not know that they would participate in the conference).

The conference in 2019 was held in the city of Graz (Austria), the mid-conference excursion was held in the mountains around the village of Neumarkt. The conference venue and excursions were successfully chosen. Graz is a very old city, the second after Vienna in economic importance. In the town of Graz, I was impressed with the Graz botanical garden, with a large collection of tropical plants. The collections of botanical gardens are of direct interest for me. I worked in two botanical gardens in Kyiv and previously specially visited botanical gardens in Ukraine and other countries, growing plants is my job and a hobby that I adore. Most of all I was impressed with the conference in the mountains. I have never been to such high mountains. The wildlife in these mountains is wonderful. I, with several participants from Ukraine, found several species of rare orchids during the excursion tour. I got acquainted with the species diversity of mountain meadows and forests in the area of the village of Neumarkt. Now it's hard for me to describe the emotions that I experienced in the mountains. It was a delight and ecstasy from the beauty of nature, fresh and clean mountain air and the aromas of herbs and moist soil, which harmoniously merged into a single picture. Thanks to the organizers, you gave me not just the opportunity to present my work and exchange knowledge, you gave me emotions and inspiration.

PS: In 2020, the Field Workshop will be held in Ukraine. If anybody (I mean participants), has the desire and opportunity to get acquainted with the nature of not only southern and central Ukraine - You are welcome, I can be "an excursion guide". In Ukraine, we have the Carpathian Mountains - the pearl of Ukraine. You can contact me about Ukraine nature information. Hope to see all new friends at the next conferences. 


\section{GrassPlot v. 2.00 - first update on the database of multi-scale plant diversity in Palaearctic grasslands}

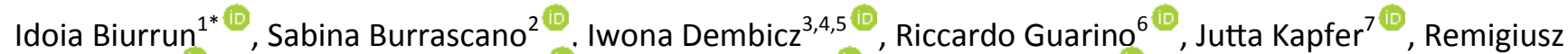

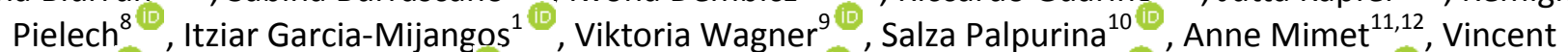

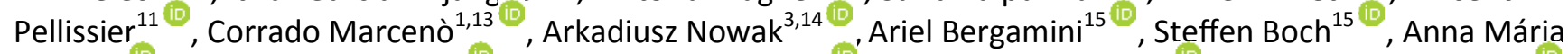
Csergö $^{16(0)}$, John-Arvid Grytnes ${ }^{17}$, Juan Antonio Campos ${ }^{10}$, Brigitta Erschbamer ${ }^{18(\mathbb{1}}$, Borja Jiménez-Alfaro ${ }^{19(0)}$, Zygmunt Kącki $^{20}$, Anna Kuzemko ${ }^{13,21}$, Michael Manthey ${ }^{22}$ Koenraad van Meerbeek $^{23}{ }^{(\mathbb{E}}$, Grzegorz Swacha $^{21}$, Elias Afif ${ }^{24}$, Juha M. Alatalo ${ }^{25,26 \mathbb{E}}$, Michele Aleffi ${ }^{27}{ }^{\mathbb{E}}$, Manuel Babbi ${ }^{5}$, Zoltán Bátori ${ }^{28}{ }^{\mathbb{E}}$. Elena

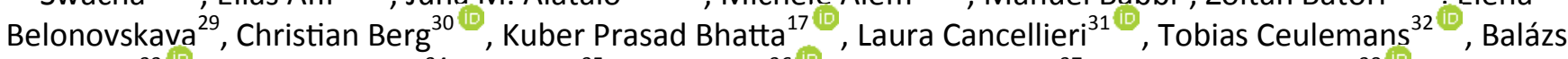
Deák $^{33}{ }^{\circledR}$, László Demeter ${ }^{34}$, Lei Deng ${ }^{35}$, Jiří Doležal ${ }^{36}{ }^{\circledR}$. Christian Dolnik ${ }^{37}$, Wenche Dramstad $^{38}$, Pavel

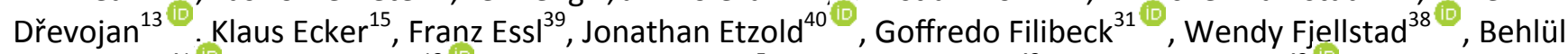
Güler $^{41}$, Michal Hájek ${ }^{13}$, Daniel Hepenstrick ${ }^{5}$, John G. Hodgson ${ }^{42}$, João P. Honrado ${ }^{43}$, Annika K.

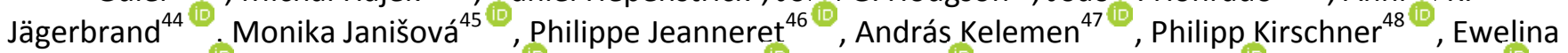

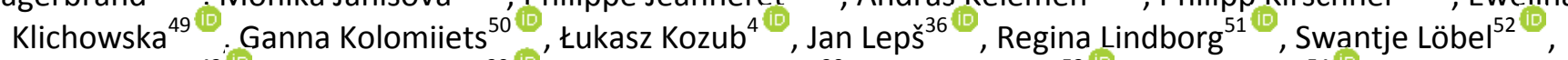

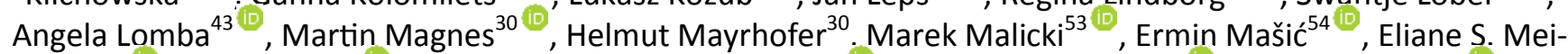
$\mathrm{er}^{46(\mathbb{1})}$, Denis Mirin ${ }^{55}$, Ulf Molau ${ }^{56}$. Ivan Moysiyenko ${ }^{57}$, Alireza Naqinezhad ${ }^{58(\mathbb{C})}$, Josep M. Ninot ${ }^{59}$ Marcin Nobis ${ }^{49}{ }^{(0)}$, Christian Pedersen ${ }^{38}{ }^{(\mathbb{1}}$, Aaron Pérez-Haase ${ }^{59,60}$, Jan Peters $^{61}$, Eulàlia Pladevall-Izard ${ }^{59(0)}$, Jan

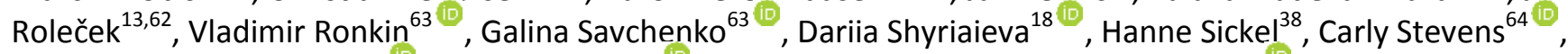
Sebastian Świerszcz ${ }^{3}$, Csaba Tölgyesi $^{28}{ }^{(0)}$, Nadezda Tsarevskaya ${ }^{29}$, Orsolva Valkó ${ }^{47}{ }^{\circledR}$, Carmen Van Mechelen $^{65}$, Iuliia Vashenyak ${ }^{66}$, Ole Reidar Vetaas ${ }^{67}{ }^{(0)}$, Denys Vynokurov ${ }^{13,18}{ }^{(\mathbb{E}}$, Emelie Waldén ${ }^{51}$, Stefan

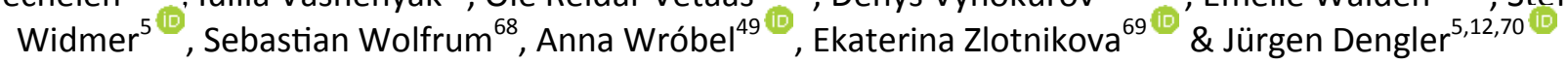

${ }^{1}$ Department of Plant Biology and Ecology, University of the Basque Country UPV/EHU, P.O. Box 644, 48080 Bilbao, Spain; idoia.biurrun@ehu.es; itziar.garcia@ehu.es, marceno.corrado@gmail.com, juanan.campos@ehu.es

${ }^{2}$ Department of Environmental Biology, Sapienza University of Rome, P.le Aldo Moro 5, 00185 Rome, Italy; sabina.burrascano@uniroma1.it

${ }^{3}$ Botanical Garden Center for Biological Diversity Conservation in Powsin, Polish Academy of Sciences, Prawdziwka St. 2, 02-973 Warsaw, Poland; i.dembicz@gmail.com,anowak@uni.opole.pl,seb.swierszcz@gmail.com ${ }^{4}$ Department of Plant Ecology and Environmental Conservation, Faculty of Biology, University of Warsaw, ul. Żwirki i Wigury 101, 02-089 Warsaw, Poland; lukasz.kozub@biol.uw.edu.pl

${ }^{5}$ Vegetation Ecology Group, Institute of Natural Resource Sciences (IUNR), Zurich University of Applied Sciences (ZHAW), Grüentalstr. 14, 8820 Wädenswil, Switzerland; babb@zhaw.ch,_hepe@zhaw.ch, stefan.widmer@zhaw.ch,juergen.dengler@uni-bayreuth.de

${ }^{6}$ Department STEBICEF, Botanical Unit, University of Palermo, via Archiarafi 38, 90123 Palermo, Italy; guarinotro@hotmail.com

${ }^{7}$ Department of Landscape Monitoring, Norwegian Institute of Bioeconomy Research, Holtvegen 66, 9269 Troms $\varnothing$, Norway; jutta.kapfer@nibio.no

${ }^{8}$ Department of Forest Biodiversity, Faculty of Forestry, University of Agriculture in Kraków, al. 29 Listopada 46, 31-425 Kraków, Poland; remekpielech@gmail.com

${ }^{9}$ Department of Biological Sciences, University of Alberta, Edmonton, $A B$, T6G 2R3, Canada; viktoria.wagner@ualberta.ca

${ }^{10}$ Department of Plant and Fungal Diversity and Resources, Institute of Biodiversity and Ecosystem Research, Bulgarian Academy of Sciences, Acad. G. Bonchev, bl. 23, 1113 Sofia, Bulgaria; salza.palpurina@gmail.com ${ }^{11}$ Department Computational Landscape Ecology, Helmholtz Centre for Environmental Research - UFZ, Permoserstraße 15, 04318 Leipzig, Germany; anne.mimet@gmail.com, vincent.pellissier@gmail.com
${ }^{12}$ German Centre for Integrative Biodiversity Research (iDiv) Halle-JenaLeipzig, Deutscher Platz 5e, 04103 Leipzig, Germany

${ }^{13}$ Department of Botany and Zoology, Faculty of Science, Masaryk University, Kotlářská 2, 61137 Brno, Czech Republic; anyameadow.ak@gmail.com, pavel.drevojan@seznam.cz, hajek@sci.muni.cz,__honza.rolecek@centrum.cz, phytosocio@ukr.net

${ }^{14}$ Institute of Biology, University of Opole, Oleska St., 45-052 Opole, Poland ${ }^{15}$ Biodiversity \& Conservation Biology, WSL Swiss Federal Research Institute, Zürcherstrasse 111, 8903 Birmensdorf, Switzerland; ariel.bergamini@wsl.ch, steffen.boch@wsl.ch, klaus.ecker@wsl.ch

${ }^{16}$ Department of Botany and Soroksár Botanical Garden, Faculty of Horticultural Science, Szent István University, Villány Street 29-43, 1118 Budapest, Hungary; Csergo.Anna.Maria@kertk.szie.hu

${ }^{17}$ Department of Biological Sciences, University of Bergen, Postbox 7803, 5020 Bergen, Norway; jon.grytnes@uib.no, kuber.bhatta@uib.no

${ }^{18}$ Department of Botany, University of Innsbruck, Sternwartestr. 15, 6020 Innsbruck, Austria; brigitta.erschbamer@uibk.ac.at

${ }^{19}$ Research Unit of Biodiversity (CSIC, UO, PA), Oviedo University, Campus de Mieres, 33600 Mieres, Spain; borja.jimenez-alfaro@botanik.uni-halle.de ${ }^{20}$ Botanical Garden, University of Wrocław, Sienkiewicza 23, 50-335 Wrocław, Poland; zygmunt.kacki@uwr.edu.pl, grzegorz.swacha@uwr.edu.pl

${ }^{21}$ Geobotany and Ecology Department, M.G. Kholodny Institute of Botany NAS of Ukraine, Tereschenkivska str. 2, 1601 Kyiv, Ukraine; darshyr@gmail.com

${ }^{22}$ Institute of Botany and Landscape Ecology, Greifswald University, Soldmannstr. 15, 17487 Greifswald, Germany; manthey@uni-greifswald.de ${ }^{23}$ Division of Forest, Nature and Landscape, Department of Earth and Environmental Sciences, KU Leuven, Celestijnenlaan 200e, 3001 Leuven, Belgium; koenraad.vanmeerbeek@kuleuven.be 
${ }^{24}$ Agroforestry Engineering Area, Department of Organisms and Systems Biology, Polytechnic School of Mieres, Oviedo University, Gonzalo Gutiérrez de Quirós s/n, 33600 Mieres, Asturias, Spain; elias@uniovi.es

${ }^{25}$ Department of Biological and Environmental Sciences, Qatar University, 2713 Doha, Qatar; jalatalo@qu.edu.qa

${ }^{26}$ Environmental Science Center, Qatar University, 2713 Doha, Qatar

${ }^{27}$ School of Biosciences and Veterinary Medicine, Plant Diversity \& Ecosystems Management Unit, Bryology Laboratory \& Herbarium, University of Camerino, Via Pontoni 5, 62032 Camerino (MC), Italy; michele.aleffi@unicam.it

${ }^{28}$ Department of Ecology, University of Szeged, Közép fasor 52, 6726 Szeged, Hungary; zbatory@gmail.com, festuca7@yahoo.com

${ }^{29}$ Institute of Geography, Russian Academy of Sciences, Staromonetny per., 29,119017 Moscow, Russia; ebelonovskaya.0709@gmail.com, ngtsar@yandex.ru

${ }^{30}$ Department of Plant Sciences, Institute of Biology, University of Graz, Holteigasse 6, 8010 Graz, Austria; christian.berg@uni-graz.at, martin.magnes@uni-graz.at, helmut.mayrhofer@uni-graz.at

${ }^{31}$ Department of Agricultural and Forestry Sciences (DAFNE), University of Tuscia, via San Camillo de Lellis snc, 01100 Viterbo, Italy; cancellieri@unitus.it, filibeck@unitus.it

${ }^{32}$ Plant Conservation and Population Biology, Department of Biology, KU Leuven, Kasteelpark Arenberg 31 box 2435, 3001 Leuven, Belgium; tobias.ceulemans@bio.kuleuven.be

${ }^{33}$ MTA-DE Biodiversity and Ecosystem Services Research Group, Hungarian Academy of Sciences, Egyetem tér 1, 4032 Debrecen, Hungary; debalazs@gmail.com

${ }^{34}$ State Agency for Protected Areas, pta. Libertatii nr. 5, 530140 MiercureaCiuc, Romania; demeter.bio.eco@gmail.com

${ }^{35}$ State Key Laboratory of Soil Erosion and Dryland Farming on the Loess Plateau, Institute of Soil and Water Conservation, Northwest A\&F University, NO. 26 Xinong Road, 712100 Yangling, China; leideng@ms.iswc.ac.cn

${ }^{36}$ Department of Botany, Faculty of Science, University of South Bohemia, Branisovska 31, 37005 Ceske Budejovice, Czech Republic; iiriddolezal@gmail.com,suspa@prf.jcu.cz

${ }^{37}$ Ecology Centre Kiel, Kiel University, Olshausenstr. 40, 24098 Kiel, Germany; cdolnik@ecology.uni-kiel.de

${ }^{38}$ Department of Landscape Monitoring, Norwegian Institute of Bioeconomy Research, P.O. Box 115, 1431 Ås, Norway; wenche.dramstad@nibio.no, wendy.jjellstad@nibio.no,

hanne.sickel@nibio.no

${ }^{39}$ Division of Conservation Biology, Vegetation and Landscape Ecology, Department of Botany and Biodiversity Research, University of Vienna, Rennweg 14, 1030 Vienna, Austria; franz.essl@univie.ac.at

${ }^{40}$ ESTOK UG, Elbestr. 97, 16321 Bernau (bei Berlin), Germany; jetzold@posteo.de

${ }^{41}$ Biology Education, Dokuz Eylul University, Uğur Mumcu Str. 135. No: 5 , 35380 Buca, İzmir, Turkey; behlul.guler2@gmail.com

${ }^{42}$ Animal and Plant Sciences Sheffield University, Alfred Denny Building, Western Bank, S10 2TN Sheffield, United Kingdom; j.hodgson@sheffield.ac.uk

${ }^{43}$ Research Centre in Biodiversity and Genetic Resources (CIBIO) - Research Network in Biodiversity and Evolutionary Biology (InBIO), University of Porto, Campus Agrário de Vairão, Rua Padre Armando Quintas, no 7, 4485641 Vairão, Vila do Conde, Portugal; jhonrado@fc.up.pt, angelalomba@fc.up.pt

${ }^{44}$ Department of Construction Engineering and Lighting Science, School of Engineering, Jönköping University, P. O. Box 1026, 551 11, Jönköping, Sweden; annika.jagerbrand@ju.se

${ }^{45}$ Institute of Botany, Plant Science and Biodiversity Center, Slovak Academy of Sciences, Ďumbierska 1, 97411 Banská Bystrica, Slovakia; monika.janisova@gmail.com
${ }^{46}$ Research Division Agroecology and Environment, Agroscope, Reckenholzstrasse 191, 8046 Zürich, Switzerland; philippe.jeanneret@agroscope.admin.ch, meier.eliane@gmail.com

${ }^{47}$ MTA-DE Lendület Seed Ecology Research Group, Hungarian Academy of Sciences, Egyetem tér 1, 4032 Debrecen, Hungary; kelemen.andras12@gmail.com, valkoorsi@gmail.com

${ }^{48}$ Naturpark Kaunergrat Pitztal - Fließ - Kaunertal, Gachenblick 100, 6251 Fließ, Austria; philipp.kirschner@gmail.com

${ }^{49}$ Institute of Botany, Jagiellonian University, Gronostajowa 3, 30-387 Kraków, Poland; ewelinaklichowska@gmail.com, m.nobis@uj.edu.pl, anna.wrobel@doctoral.uj.edu.pl

${ }^{50}$ National Nature Park "Buzky Gard", 85, Pervomaiska str., 55223 Mygyia, Mykolaiv region Ukraine; koloanka@gmail.com

${ }^{51}$ Dept. of Physical Geography, Stockholm University, 10691 Stockholm, Sweden; regina.lindborg@natgeo.su.se,walden.emelie@gmail.com

${ }^{52}$ Landscape Ecology and Environmental Systems Analysis, Institute of Geoecology, TU Braunschweig, Langer Kamp 19c, 38106 Braunschweig, Germany; s.loebel@tu-braunschweig.de

${ }^{53}$ Department of Botany, University of Wrocław, ul. Kanonia 6/8, 50-328 Wrocław, Poland; malickimarek@interia.pl

${ }^{54}$ Department of Biology, Faculty of Science, University of Sarajevo, Zmaja od Bosne 33-35, 71000 Sarajevo, Bosnia and Herzgovina; erminmasic@hotmail.com

${ }^{55}$ Department of Vegetation Science and Plant Ecology, Biological faculty, St. Petersburg State University, Universitetskaja emb., 7/9, 199034 Saint Petersburg, Russia; mirin denis@mail.ru

${ }^{56}$ Department of Biological and Environmental Sciences, University of Gothenburg, P.O. Box 461, 40530 Gothenburg, Sweden; ulf.molau@bioenv.gu.se

${ }^{57}$ Department of Botany, Kherson State University, Universytetska St. 27, 73000 Kherson, Ukraine; ivan.moysiyenko@gmail.com

${ }^{58}$ Department of Biology, Faculty of Basic Sciences, University of Mazandaran, P.O. Box 47416-95447, Babolsar, Iran; a.naqinezhad@umz.ac.ir

${ }^{59}$ Department of Evolutionary Biology, Ecology and Environmental Sciences, Universitat de Barcelona, Av. Diagonal 643, 08028 Barcelona, Spain; jninot@ub.edu, aaronperez@ub.edu, eulalia.pladevall@gmail.com

${ }^{60}$ Department of Biosciences, University of Vic, Carrer de la Laura 13, 08500 Vic, Spain

${ }^{61}$ Michael-Succow-Foundation, Ellernholzstr. 1/3, 17489 Greifswald, Germany; jan.peters@succow-stiftung.de

${ }^{62}$ Department of Vegetation Ecology, Institute of Botany, Czech Academy of Sciences, Lidická 25/27, 60200 Brno, Czech Republic

${ }^{63}$ Department of Zoology and Animal Ecology, V.N. Karazin Kharkiv National University, 4 Svobody Sq, 61022 Kharkiv, Ukraine; ronkinvl@gmail.com, savchgala5@gmail.com

${ }^{64}$ Lancaster Environment Centre, Lancaster University, LA1 4YQ Lancaster, United Kingdom; c.stevens@lancaster.ac.uk

${ }^{65}$ PXL Bio-Research, PXL University College, Agoralaan H, 3590 Diepenbeek, Belgium; carmen.vanmechelen@pxl.be

${ }^{66}$ Vasul' Stus Donetsk National University, $600^{\text {th }}$ Anniversary Street, 21021, Vinnytsia, Ukraine; arrhenatherum@gmail.com

${ }^{67}$ Department of Geography, University of Bergen, Fosswinckelsgate 6, 5020 Bergen, Norway; Ole.Vetaas@uib.no

${ }^{68}$ Life Science Center Weihenstephan, Technische Universität München, Liesel-Beckmann-Straße 2, 85354, Freising, Germany; sebastian.wolfrum@tum.de

${ }^{69}$ Training Department, Stroyproekt Engineering Group, Dunaisky prospect 13A, 196158, Saint Petersburg, Russia; ezlotnikova@stpr.ru

${ }^{70}$ Plant Ecology, Bayreuth Center of Ecology and Environmental Research (BayCEER), University of Bayreuth, Universitätsstr. 30, 95447 Bayreuth, Germany 
Palaearctic Grasslands 44 (2019): 26-47

Abstract: GrassPlot is a collaborative vegetation-plot database organised by the Eurasian Dry Grassland Group (EDGG) and listed in the Global Index of Vegetation-Plot Databases (GIVD ID EU-00-003). Following a previous Long Database Report (Dengler et al. 2018, Phytocoenologia 48, 331-347), we provide here the first update on content and functionality of GrassPlot. The current version (GrassPlot v. 2.00) contains a total of 190,673 plots of different grain sizes across 28,171 independent plots, with 4,654 nested-plot series including at least four grain sizes. The database has improved its content as well as its functionality, including addition and harmonization of header data (land use, information on nestedness, structure and ecology) and preparation of species composition data. Currently, GrassPlot data are intensively used for broad-scale analyses of different aspects of alpha and beta diversity in grassland ecosystems.

Keywords: biodiversity; community ecology; Eurasian Dry Grassland Group (EDGG); Global Index of Vegetation-Plot Databases (GIVD); grassland vegetation; GrassPlot; macroecology; nested plot; Palaearctic; scale dependence; species-area relationship (SAR); vegetationplot database.

Abbreviations: EDGG = Eurasian Dry Grassland Group; EVA = European Vegetation Archive; GIVD = Global Index of Vegetation-Plot Databases; GrassPlot = Database of Scale-Dependent Phytodiversity Patterns in Palaearctic Grasslands; SAR = species-area relationship.

Submitted: 25 November 2019; first decision: 11 December 2019; accepted: 12 December 2019

Scientific Editor: Frank Yonghong Li

Linguistic Editor: Richard Jefferson

\section{Introduction}

Since 2009, the Eurasian Dry Grassland Group (EDGG) has been conducting Field Workshops in various regions of the Palaearctic realm to collect high-quality multi-scale diversity and composition data of various, mostly dry grassland types (e.g. Turtureanu et al. 2014; Kuzemko et al. 2016; Polyakova et al. 2016; for overview of the sampled data, see Dengler et al. 2016a) following the same sampling methodology (Dengler et al. 2016b). In March 2017, the establishment of the collaborative vegetation-plot database GrassPlot allowed merging the data collected by the EDGG with the previously established "Database Species-Area Relationships in Palaearctic Grasslands" (Dengler et al. 2012). The resulting GrassPlot database is registered in the Global Index of Vegetation-Plot Databases (Dengler et al. 2011) under ID EU-00-003 (Dengler et al. 2018) and contains vegetation-plot data of grasslands in the widest sense (i.e. any vegetation type except forests, tall shrublands, aquatic and segetal communities) from the Palaearctic biogeographic realm (i.e. Europe, North Africa, and West, Central, North and Northeast Asia). The focus of GrassPlot is on data of precisely delimited plots, both multi-grain, nested-plot data of any plot size and single-grain data matching one of eight EDGG standard grain sizes (Dengler et al. 2018).

The purpose of GrassPlot is to provide quality data for broad -scale analyses of various aspects of vegetation diversity. The concept of GrassPlot and the content of its first public version 1.00 have been described by Dengler et al. (2018). Since this publication, GrassPlot data have been intensively used for broad-scale biodiversity analyses, such as speciesarea relationships (SARs) in continuous vegetation (Dengler et al. 2019), or manuscripts in preparation on small-scale beta diversity, and "benchmarking" Palaearctic grassland diversity. At the same time, the content and functionality of GrassPlot have significantly increased. This paper provides an overview of the improvements in the structure and content of the database since version 1.00 .

\section{New functionalities}

\section{Addition and harmonization of header data}

Information on nestedness. GrassPlot includes both singlegrain data (hereafter individual plots) and nested-plot data consisting of subplots of several grain sizes, often replicated per grain size. All subplots of a nested series are included in one macro plot or mother plot, also with a complete species list (hereafter largest subplot). We have added several binary $(\mathrm{Y} / \mathrm{N})$ header data to document different aspects of nestedness: Individual plot, Independent plot (individual plots and largest subplots combined), Belonging to nested series with at least 2 sizes, Belonging to nested series with at least 4 sizes, Belonging to nested series with at least 7 sizes, and Perfect nesting. The latter indicates if the nested series corresponds to a perfect nesting or not, e.g., if all subplots of a certain size are included in the next larger subplot (Fig. 1). The additional column Distorting sizes indicates which are the grain sizes that are impeding the perfect nesting; if these distorting sizes were removed, a perfect nesting would result. Fig. 1 shows schemes of the three main types of nested sampling designs in GrassPlot, two with perfect nesting (Figs. 1a, 1b) and a third one with non-perfect nesting (Fig. 1c).

Grassland types and biomes. Data collected in GrassPlot represent different types of grasslands in the broadest sense. To allow future users and projects to deal with this considerable diversity of vegetation, we created a two-level vegetation typology with 22 vegetation types grouped into six broad groups: natural grasslands, secondary grasslands, azonal habitats, dwarf shrublands, tall forb and ruderal communities, and deserts and semi-deserts (Table 1). We also created expert rules to assign phytosociological syntaxa already included in GrassPlot to these 22 vegetation types (Table 2). Vegetation type was assigned based on phytosociological affinity or on other information provided by data 


\section{Perfect nesting}

a)

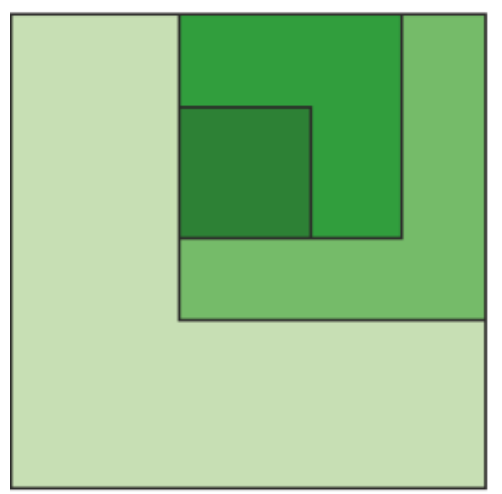

\section{Non-perfect nesting}

\section{c)}
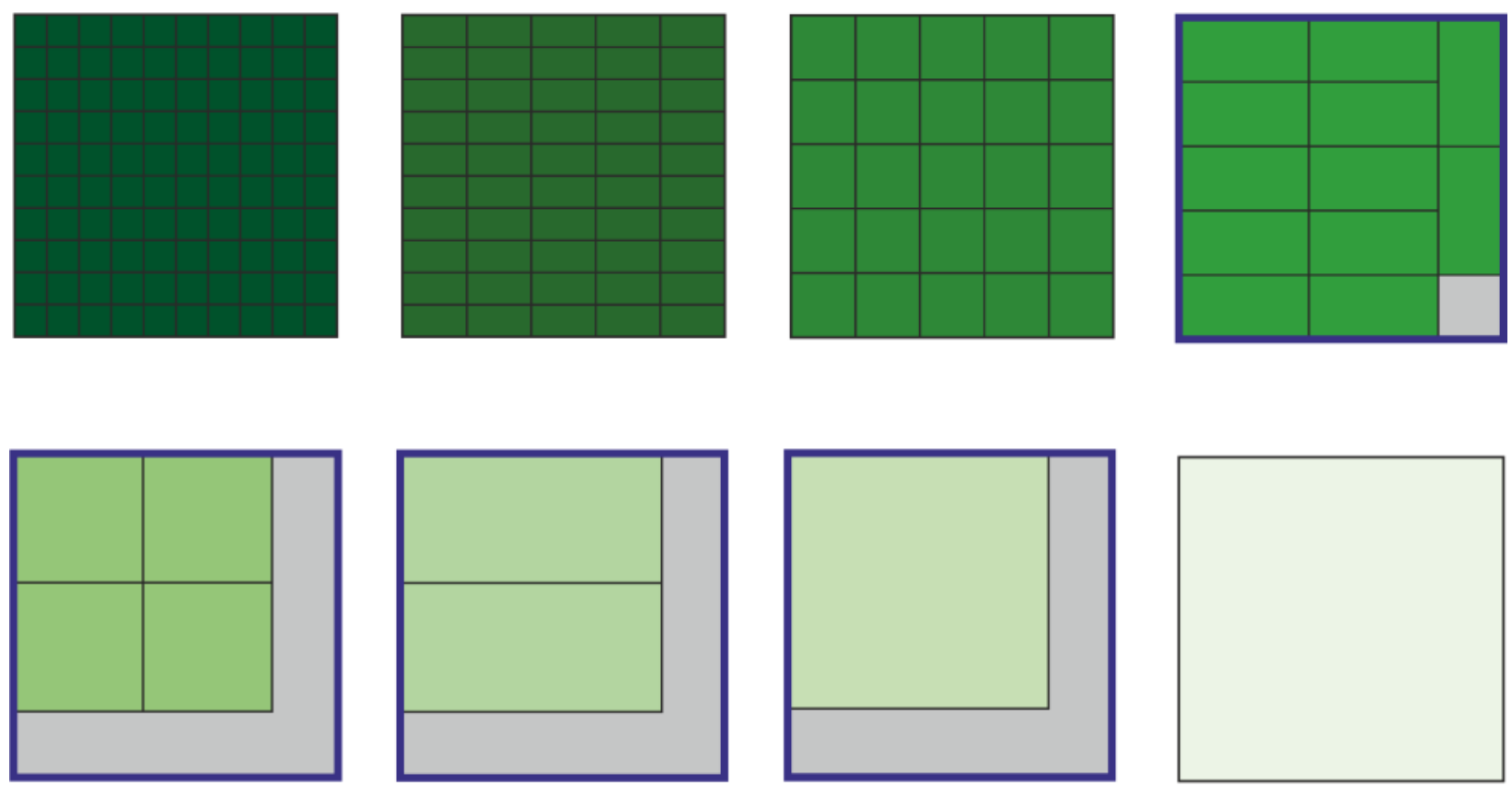

subplots

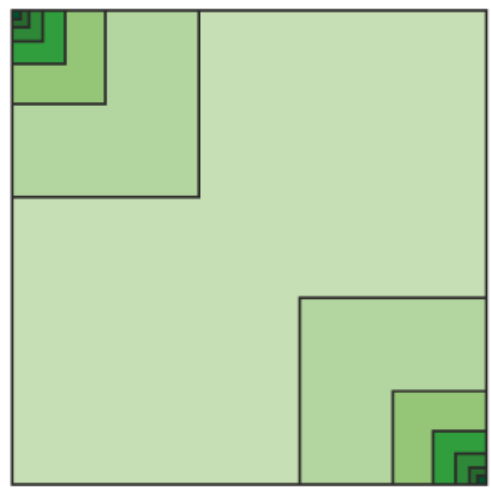


Table 1. Two-level vegetation typology applied in GrassPlot v. 2.00. Since the assignments to the vegetation types and groups were largely based on syntaxonomy, there are some grey zones, e.g. some xeric grasslands might be secondary.

\begin{tabular}{|c|c|}
\hline Group & Vegetation type \\
\hline \multirow{4}{*}{ Natural grasslands } & Alpine grasslands \\
\hline & Alpine steppes \\
\hline & Rocky grasslands \\
\hline & Xeric grasslands and steppes \\
\hline \multirow{5}{*}{ Secondary grasslands } & Wet grasslands \\
\hline & Mesic grasslands \\
\hline & Meso-xeric grasslands \\
\hline & Mediterranean grasslands \\
\hline & Sandy dry grasslands \\
\hline \multirow{5}{*}{ Azonal habitats } & Wetlands \\
\hline & Saline communities \\
\hline & Dunes \\
\hline & Rocks and screes \\
\hline & Saline steppes and semi-deserts \\
\hline \multirow{3}{*}{ Dwarf shrublands } & Arctic-alpine heathlands \\
\hline & Lowland heathlands \\
\hline & Garrigues and thorn cushion communities \\
\hline \multirow{2}{*}{$\begin{array}{l}\text { Tall forb and ruderal } \\
\text { communities }\end{array}$} & Tall forb and fringe communities \\
\hline & Ruderal communities \\
\hline \multirow{3}{*}{$\begin{array}{l}\text { Deserts and semi- } \\
\text { deserts }\end{array}$} & Alpine deserts \\
\hline & Cold deserts and semi-deserts \\
\hline & Warm deserts and semi-deserts \\
\hline
\end{tabular}

collectors, e.g., vernacular names, species composition, localisation, and so on.

We also assigned each plot both to biomes and to geographic regions. For biomes, we used the recent classification by Bruelheide et al. (2019, based on Schultz 2005), which recognizes ten terrestrial biomes, all of them occurring in the Palaearctic realm, except "Tropics with yearround rain". We have assigned all plots in GrassPlot to one of these nine biomes using plot coordinates. As a result, all biomes present in the Palaearctic realm except "Tropics with summer rain", that occurs marginally on the Arabian Peninsula, are represented in GrassPlot. For geographic regionalization, we used Törok \& Dengler (2018) and Dengler et al. (in press).

Land-use data. Land use is the main current driver of biodiversity change and loss worldwide (Collins et al. 1998). Vegetation survey databases provide spatially explicit information on local biodiversity (richness and/or composition). However, associated land-use information is generally scarce (but see Niedrist et al. 2009; Hudson et al. 2014). The lack of reliably coupled biodiversity and land-use data at a local scale that is available over large geographic extents substantially impedes our understanding of how biodiversity responds to anthropogenic environmental change.

The current version of GrassPlot now includes consistent and standardized information on the land use and land-use intensity of the plots. Information on land-use was provided by data contributors with different degrees of detail. It has been structured into 19 different land-use variables, created to capture as much information as possible from existing datasets. The structure of the land-use data has been developed to meet the needs of future analyses regarding land use-data and to guide future sampling efforts. The 19 landuse variables are structured into four categories: land-use type (seven variables), land-use intensity and details (relative to each land-use type), land destination (for what purpose the land is used) and naturalness degree (see Table 3). Each grassland has one or several land-use types (for example it can be mown and fertilized), and a grassland can be mown for different purposes (land destination) such as farming (feeding cattle) or managing a public park (recreational destination). Land destination is a coarse categorisation which is expected to include several types of management practices.

Importantly, all plots of the GrassPlot database $(190,673$ plots) now have a land-use type, while other land-use variables are not available for all plots, indicated as NA (Table 3). Moreover, the variable Naturalness degree is still under development, and will be added when it is computed.

Environmental and structural data. GrassPlot v. 2.00 has also notably improved the coverage and consistency of several environmental and structural header data, which are stored with standardized measurement units. Topographic data are readily and consistently available for many plots with different degrees of coverage, e.g. 88\% for Elevation, 34\% for Aspect and Inclination, 5\% for Microrelief. Microrelief is defined as the maximum distance to the ground when placing a stick on the ground in the most rugged part of the plot, measured perpendicular to the stick. The soil data with better coverage are $\mathrm{pH} \mathrm{H}_{2} \mathrm{O}(15 \%)$, Soil texture class $(14 \%)$, Conductivity (10\%) and Soil depth (10\%). Of the structural header data, Tree cover (95\%), Shrub cover (50\%), Herb cover (49\%), Total vegetation cover (39\%) and Cryptogam cover $(37 \%)$ are the variables with better coverage. Additionaly, Litter cover is provided for $31 \%$ of plots, Proportion of stones, gravel and fine soil for $21 \%$ of plots and Mean height of the herb layer for $13 \%$ of plots. All environmental and structural data stored in GrassPlot have been directly measured or estimated in the field, or, in the case of soil parameters, in the laboratory using soil samples collected in the plots. Climatic and more complete topographic data can be retrieved from digital models using plot geographic coordinates, but the database is focused on directly measured data. Of course, projects using GrassPlot data may be able to combine them with environmental data extracted from digital models.

\section{Preparation of species composition data}

As reported by Dengler et al. (2018), the GrassPlot database also includes species composition data for most datasets (93\%). This means that for $90.7 \%$ of the plots (Table 4 ), in addition to species richness data, there is also a complete list of vascular plant species and often also of lichens and 
Table 2. Assignment rules for phytosociological syntaxa to the 22 vegetation types as defined in GrassPlot v. 2.00, given at class level. Classes occurring in Europe are named after Mucina et al. (2016), classes from outside Europe according to various sources (Ermakov \& Krestov 2009; Wehrden et al. 2009; Ermakov et al. 2014; Noroozi et al. 2014; Reinecke et al. 2017; Hüseynova \& Yalçin 2018; Nowak et al. 2018). Classes absent in GrassPlot data are not shown in the table. For the classes with the notation p.p., the assignment is made at order or alliance level (not shown here).

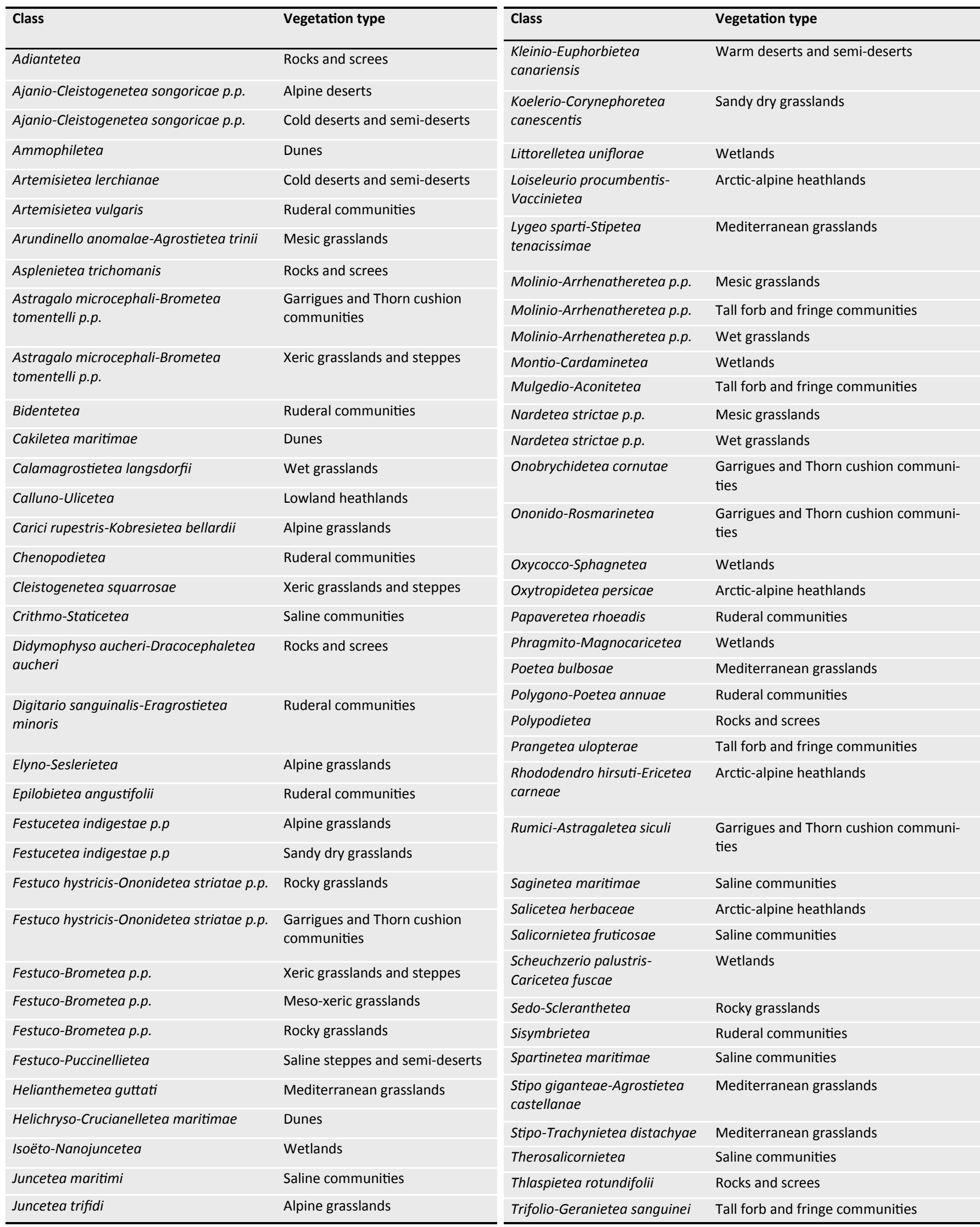


Table 3. Land-use variables in GrassPlot v. 2.00 and the percentage of plots for which the information is available (\% F). The percentages refer to the independent plots $(N=\mathbf{2 8 , 1 7 1})$. For binary variables, the column "\% 1 in $F$ " indicates the percentage frequency of the management technique among the plots that have this land-use information. Some plots have a combined land use (mown and grazed; natural and grazed; etc.), so the sum of plots in each specific land use can exceed the total number of plots in GrassPlot. "NA" indicates missing information.

\begin{tabular}{|c|c|c|c|c|c|}
\hline Variable group & Variable name & Variable type & Possible values & $\% F($ no NA) & $\begin{array}{l}\% 1 \text { in } F \\
\text { (no } 0, \text { no NA) }\end{array}$ \\
\hline \multirow[t]{7}{*}{ Land-use type } & Mown & binary & $0 / 1$ & 90.3 & 11.3 \\
\hline & Grazed & binary & $0 / 1$ & 89.3 & 62.8 \\
\hline & Burnt & binary & $0 / 1$ & 69.2 & 2.3 \\
\hline & Fertilized & binary & $0 / 1$ & 65.0 & 2.2 \\
\hline & Abandoned & binary & $0 / 1$ & 67.2 & 19.1 \\
\hline & Natural & binary & $0 / 1$ & 45.0 & 49.0 \\
\hline & Other & text & free & & \\
\hline \multirow{10}{*}{$\begin{array}{l}\text { Land-use intensi- } \\
\text { ty and details }\end{array}$} & Grazing intensity & numeric & 0 to 1 & 28.6 & \\
\hline & Grazing load & numeric & 0 to infinity & 9.8 & \\
\hline & Grazing animal & text & free & 18.3 & \\
\hline & Mowing frequency & numeric & 0 to infinity & 10.4 & \\
\hline & Burning frequency & numeric & 0 to 1 & 2.3 & \\
\hline & Fertilization intensity & numeric & 0 to 1 & 12.9 & \\
\hline & Fertilization type & text & synthetic/natural & 0.9 & \\
\hline & Fertilization details & text & free & 0.9 & \\
\hline & Years since abandonment & numeric & 0 to infinity & 2.2 & \\
\hline & Abandonment: former land use & text & arable, mown, grazed & 7.1 & \\
\hline Land destination & Land destination & text & $\begin{array}{l}\text { cropland, farmland, } \\
\text { recreational }\end{array}$ & 33.2 & \\
\hline Naturalness & Naturalness degree & numeric & 0 to 3 & - & \\
\hline
\end{tabular}

bryophytes, either as presence/absence or coverabundance information. This is the result of the work carried out between GrassPlot versions 1.00 and 2.00 to integrate the species composition data into a single uniform structure.

Most of the datasets were supplied as species $\times$ plot matrices ("wide tables"). Since such wide format data are neither suitable for merging into a single dataset nor can be filtered for functional groups or vegetation layers, they were transformed into a "long format" (see example in Appendix 1) using different packages suitable for data manipulation in $\mathrm{R}$ (e.g. plyr, dplyr and tidyr) (Wickham et al. 2017; Wickham \& Henry 2019). In the long format, each row consists of a species record, i.e., an occurrence of a species in a plot or subplot. Additional columns provide information on plant group, vegetation layer, species abundance and abundancescale. Abundance-scale is a binary column, indicating whether the value in Abundance column is a presence/absence value $(P / A=0 / 1)$ or a cover-abundance value at the percentage scale (cover: 0-100). Cover abundance values that

Table 4. Overview of some key parameters of GrassPlot v. 2.00 covering access regime, methodological aspects and temporal and elevational distribution. The column "NA" indicates the fraction of plots in GrassPlot v. 2.00 for which the respective field is currently without content. The percentages refer to the independent plots $(N=28,171)$.

\begin{tabular}{|c|c|c|}
\hline Parameter & NA & Frequency distribution of parameter values \\
\hline \multicolumn{3}{|l|}{ Availability of data } \\
\hline Access regime & $<0.1 \%$ & 1 - restricted access (12.0\%); 2 - semi-restricted access (86.2\%); 3 - free access $(1.7 \%)$ \\
\hline Availability of compositional data & - & Yes-ready (10.0\%); Yes-in preparation (80.7); to be provided later (5.4\%); no (3.8\%) \\
\hline \multicolumn{3}{|l|}{ Methodological aspects } \\
\hline Recording method & $0.2 \%$ & Shoot presence (69.9\%); rooted presence $(29.9 \%)$ \\
\hline Plot shape & $0.1 \%$ & $\begin{array}{l}\text { Squares (81.6\%); rectangles 1:1.6 }(0.2 \%) \text {; rectangles more elongated than } 1: 2(0.3 \%) \text {; circles } \\
(18.0 \%)\end{array}$ \\
\hline Accuracy of coordinates & $0.4 \%$ & $\leq 1 \mathrm{~m}(18.3 \%) ; 1.1-10 \mathrm{~m}$ (47.5\%); 11-100 m (12.3\%); 101-1,000 m (16.4\%); > 1,000 m (5.2\%) \\
\hline \multicolumn{3}{|l|}{ Spatio-temporal distribution } \\
\hline Year of recording & - & $\begin{array}{l}\text { Before } 1980 \text { (0.1\%); 1980-1989 (10.5\%); 1990-1999 (13.3\%); 2000-2009 (17.7\%); } 2010 \text { and } \\
\text { later (59.3\%) }\end{array}$ \\
\hline Elevation & $12.0 \%$ & $\begin{array}{l}\leq 10 \mathrm{~m} \text { a.s.I. }(14.9 \%) ; 11-100 \mathrm{~m} \text { a.s.I. }(9.2 \%) ; 101-1,000 \mathrm{~m} \text { a.s.I. }(28.8 \%) ; 1,001-2,000 \mathrm{~m} \text { a.s.l. } \\
(20.1 \%) ; 2,001-3,000 \mathrm{~m} \text { a.s.l. }(8.5 \%) ; 3,001-4,000 \mathrm{~m} \text { a.s.l. }(3.7 \%) ;>4,000 \mathrm{~m} \text { a.s.l. }(2.8 \%)\end{array}$ \\
\hline
\end{tabular}


were originally measured by means of categorical scales (e.g. different variants of $\mathrm{Br}$.-Bl., Londo, and so on) have already been transformed to percentage during the wide data format by choosing the midpoint of the upper and lower boundaries of a cover class. The original cover-abundance scale has been stored in the database together with all other plot-level metadata, plus geographic, environmental, land-use and structural data. Species composition longformat tables also maintain relevant metadata such as the GrassPlot ID of the single plot or subplot of a nested-series, the ID of the largest subplot within which the subplot is nested (only for nested-plots) and its grain size. This data structure allows data to be combined within and across datasets for later analyses on species composition either by using the long format or reshaping it into a wide format of species $\times$ plot matrices.

While the data are being prepared in a long format, progress is also being made to develop a process to semiautomatically adjust species nomenclature, i.e. correcting typographical errors and homogenizing different levels of identification detail and differences in species name format (e.g. removing authorities from taxon names). This allows taxon names to be standardized according to "The Plant List" (www.theplantlist.org), using the taxonstand package (Cayuela et al. 2012) in R (R Core Team 2019). In addition, we plan to add a column named "determ_qual" to indicate for each taxon its quality of determination: 1 - determined to the species level (e.g. Viola arvensis), 0.5 - determination to species level not certain (e.g. Viola arvensis aggr., Viola cf. arvensis, Viola arvensis/kitaibeliana), 0.2 - species unknown (species epithet missing); 0 - genus unknown (e.g. Violaceae). This would allow us to calculate a "species composition quality" index for each plot as follows: the sum of the "determ_qual" values of each species in the plot divided by the total number of species. This "species composition quality" index ranges from 1 (all taxa are determined at least to the species level) to 0 (taxa at family level). The proportion of species determined to different levels will be calculated for each plot and various thresholds (based on project aims) can be used to filter out plots that do not meet species composition quality criteria.

The last step in the process of harmonizing the composition data involves dealing with homonyms and synonyms originating from different concepts of species names. Many contributed datasets also provide information on the reference flora, but collaboration with data providers will be crucial in this last step.

Currently, 76 out of the 171 datasets for which composition data have been provided to GrassPlot are already available in long format.

\section{Content of GrassPlot v. 2.00}

The current GrassPlot version 2.00 of 7 November 2019 contains data from 184 contributing datasets, i.e. 59 (47\%) more compared to GrassPlot version 1.00 (Dengler et al. 2018). The newly contributed datasets are listed in Appendix 2. In total, the database now contains 190,673 plots of different grain sizes $(+21,676$ plots or $13 \%$ added to version $1.00)$, corresponding to 28,171 independent plots. Among these are 22,422 individual plots (single-grain data) and 5,749 nested-plot series with at least two grain sizes (often consisting of several subseries), of which 4,654 contain at least four grain sizes (+1,857 or $66 \%)$ and 2,057 even seven and more grain sizes. Most contributors have assigned their plots to the "semi-restricted access" regime, but a few have allocated their plots to the "restricted access" or "free access" categories (Table 4).

GrassPlot comprises data over a wide geographic range, from the Canary Islands (Tenerife) in the west $\left(16.3^{\circ} \mathrm{W}\right)$ to Kamchatka in the east $\left(161.7^{\circ} \mathrm{E}\right)$ and from Nepal in the south $\left(28.2^{\circ} \mathrm{N}\right)$ to Svalbard (Norway) in the north $\left(77.9^{\circ} \mathrm{N}\right)$. The highest density of plots were recorded in temperate Europe (Figs. 2 and 3). In total, the plots originate from 47 countries, with Spain having the highest number $(58,977$ plots) and Austria the highest density (16.58 plots per 100 $\mathrm{km}^{2}$ ) of the total plots. Switzerland has the highest number $(5,172$ plots) and Andorra the highest density (16.45 plots per $100 \mathrm{~km}^{2}$ ) of independent plots (Table 5). Data locations range from sea level to 5,750 $\mathrm{m}$ a.s.l., with the largest fraction of independent plots coming from 101-1,000 m a.s.l. (Table 4). Sampling year is one of the metadata included for each plot, and this shows that data were sampled between 1948 and 2018, with 59.3\% of all independent plots surveyed between 2010-2019 (Table 4). Currently, 98\% of all independent plots have been assigned to one of 22 vegetation types (Table 6), with $79 \%$ of plots being syntaxonomically assigned to a class and/or subordinate syntaxa. Natural grasslands, secondary grasslands and azonal habitats are the most frequent broad groups. Within these groups, alpine grasslands and xeric grasslands and steppes, mesoxeric and mesic grasslands and saline communities and wetlands, respectively, are the most frequent vegetation types (Table 6). With respect to azonal communities, Juncetea maritimi and Scheuchzerio palustris-Caricetea fuscae are the most frequent phytosociological classes in saline communities and wetlands, respectively. The distribution of phytosociological classes across the natural and secondary grassland types is shown in Fig. 4. The temperate dry grassland class Festuco-Brometea (23\%) is present in rocky grasslands, meso-xeric grasslands and xeric grasslands and steppes, but most plots correspond to meso-xeric grasslands. The class Molinio-Arrhenatheretea (12\%) is well represented in mesic and wet grasslands, while the best-represented classes in alpine and sandy dry grasslands are Juncetea trifidi and Koelerio-Corynephoretea canescentis, respectively (Fig. 4).

The most frequent standard-plot sizes are $0.01 \mathrm{~m}^{2}$, followed by $1 \mathrm{~m}^{2}$ and $9-10 \mathrm{~m}^{2}$ (Table 7). Data of the complete vegetation (vascular plants, and terricolous bryophytes and lichens) are available for 16,515 plots (8.7\%) (Table 7). Methodologically, the majority of contributors used shoot sampling rather than rooted sampling (Table 4), which can make a big difference for the assessment of vascular plant richness at small spatial grains (Dengler 2008; Güler et al. 2016; Cancellieri et al. 2017). Among plot shapes, squares were 
Fig. 2. Spatial distribution of the independent plots contained in GrassPlot v. 2.00 shown as plot density in equally-sized grid cells of 10,000 $\mathrm{km}^{2}(N=28,171)$.
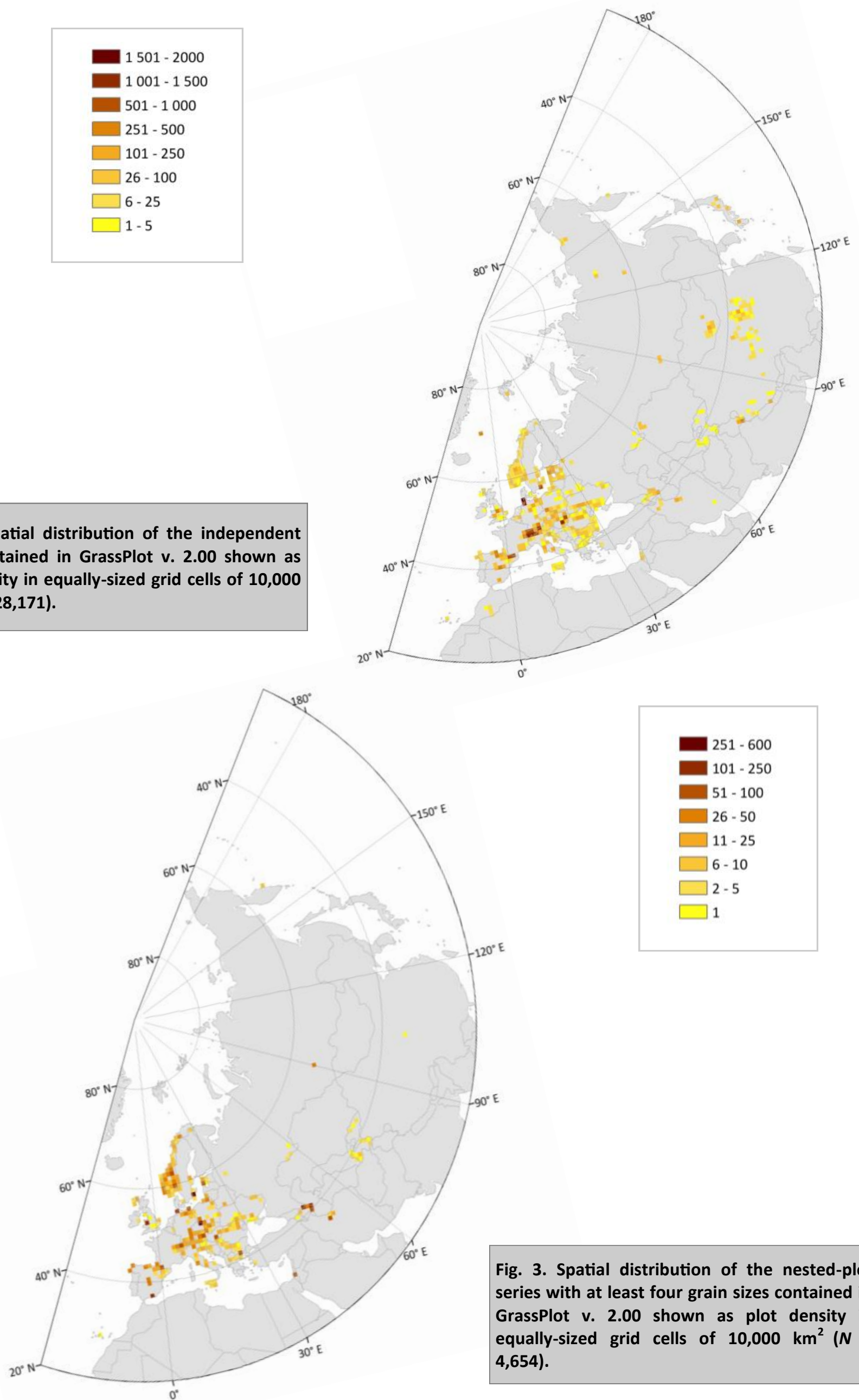

Fig. 3. Spatial distribution of the nested-plot series with at least four grain sizes contained in GrassPlot v. 2.00 shown as plot density in equally-sized grid cells of $10,000 \mathrm{~km}^{2}(N=$ 4,654). 
Table 5. Number $(N)$ and density of plots per country (or dependent territory), sorted by decreasing density of independent plots $(N=28,171)$. The twenty five countries with the highest densities are listed. Area $\left[\mathrm{km}^{2}\right]$ refers to the size of the respective territory. For comparison columns $N_{\text {all }}$ and $N_{\text {all }} / 100 \mathrm{~km}^{2}$ provide numbers and densities of all plots for the listed countries $\left(N_{\text {all }}=190,673\right)$.

\begin{tabular}{|c|c|c|c|c|c|c|}
\hline Code & Country & Area $\left[\mathrm{km}^{2}\right]$ & $N$ & $\mathrm{~N} / 100 \mathrm{~km}^{2}$ & $N_{\text {all }}$ & $N_{\text {all }} / 100 \mathrm{~km}^{2}$ \\
\hline$A D$ & Andorra & 468 & 77 & 16.45 & 77 & 16.45 \\
\hline $\mathrm{CH}$ & Switzerland & 41,285 & 5,172 & 12.52 & 6,134 & 14.86 \\
\hline HU & Hungary & 93,030 & 2,638 & 2.84 & 4,320 & 4.64 \\
\hline $\mathrm{EE}$ & Estonia & 45,100 & 832 & 1.84 & 1,578 & 3.50 \\
\hline AT & Austria & 83,855 & 1,401 & 1.67 & 13,899 & 16.58 \\
\hline DE & Germany & 356,840 & 3,684 & 1.03 & 8,359 & 2.34 \\
\hline ES & Spain & 504,790 & 3,451 & 0.68 & 58,977 & 11.68 \\
\hline$A Z$ & Azerbaijan & 86,600 & 408 & 0.47 & 2,033 & 2.35 \\
\hline SJ & Svalbard and Jan Mayen & 61,397 & 280 & 0.46 & 280 & 0.46 \\
\hline IL & Israel & 20,724 & 82 & 0.39 & 1,795 & 8.66 \\
\hline LV & Latvia & 64,589 & 250 & 0.39 & 250 & 0.39 \\
\hline $\mathrm{CZ}$ & Czech Republic & 78,864 & 280 & 0.36 & 1,396 & 1.77 \\
\hline $\mathrm{BE}$ & Belgium & 30,688 & 90 & 0.29 & 90 & 0.29 \\
\hline BG & Bulgaria & 110,910 & 315 & 0.28 & 844 & 0.76 \\
\hline HR & Croatia & 56,594 & 160 & 0.28 & 227 & 0.40 \\
\hline NO & Norway & 323,758 & 911 & 0.28 & 15,292 & 4.72 \\
\hline SK & Slovakia & 49,035 & 139 & 0.28 & 477 & 0.97 \\
\hline IT & Italy & 301,245 & 742 & 0.25 & 15,120 & 5.02 \\
\hline UK & United Kingdom & 244,587 & 586 & 0.24 & 3,756 & 1.54 \\
\hline SE & Sweden & 440,940 & 1,000 & 0.23 & 26,219 & 5.95 \\
\hline PL & Poland & 312,685 & 620 & 0.20 & 3,148 & 1.01 \\
\hline RO & Romania & 238,397 & 436 & 0.18 & 1,354 & 0.57 \\
\hline SI & Slovenia & 20,273 & 37 & 0.18 & 37 & 0.18 \\
\hline UA & Ukraine & 603,628 & 765 & 0.13 & 2677 & 0.44 \\
\hline RS & Serbia & 77,453 & 119 & 0.15 & 533 & 0.69 \\
\hline
\end{tabular}

most frequently employed (82\%), followed by circles (18\%) but rectangles are rarer. GrassPlot's geographic coordinates most often have an accuracy of $<1 \mathrm{~km}$ and in $18 \%$, of $<1 \mathrm{~m}$ (Table 4).

As explained above, header data in GrassPlot also hold many structural (e.g. cover and height of vegetation layers, biomass) and ecological (e.g. topography, soil, land use) parameters that have harmonized terminology and units of measurement. The distribution of plots across biomes and regions is shown in Fig. 5 and Table 8, respectively.

\section{Governance, applications and outlook}

GrassPlot is a self-governed consortium, associated with the Eurasian Dry Grassland Group (EDGG). The data contributors remain owners of their data and become members of the consortium. Every two years, the consortium elects from its members a seven-strong Governing Board. Since 27 February 2019, the Governing Board is composed of Jürgen Dengler (Switzerland; custodian), Idoia Biurrun (Spain, deputy custodian and database manager), Sabina Burrascano (Italy), Iwona Dembicz (Poland and Switzerland), Riccardo Guarino (Italy), Jutta Kapfer (Norway) and Remigiusz Pielech (Poland). Other consortium members act as additional data managers, such as Itziar García-Mijangos, Salza Palpurina, Anne Mimet, Corrado Marcenò and Vincent Pellissier. Rights and duties of data contributors and data users are regulated in Bylaws, of which a slightly modified version was adopted by the GrassPlot Consortium on 1 January 2019. The GrassPlot website is currently hosted at the Ecoinformatics Portal Bayreuth (https://bit.ly/2HvVkgu), but will be transferred shortly to the new EDGG website (http://www.edgg.org).

As already mentioned, the purpose of GrassPlot is to provide high-quality data for broad-scale analyses of various aspects of vegetation diversity. According to the GrassPlot Bylaws, members of the consortium can request data for research projects (and non-members can join up with a member to do so). Currently, one such paper project has been completed and three are under way. Dengler et al. (2019) recently analysed which function best describes species-area relationships (SARs) in Palaearctic grasslands. In a follow-up paper (J. Dengler, I. Dembicz et al., in prep.), the authors will test how the exponent of the power function ( $z$ value) as a measure of small-scale beta-diversity depends on taxonomic group, vegetation type and site conditions. Furthermore, an overview of mean, minimum and maximum richness data of Palaearctic grasslands across regions, vegetation types, taxa and scales will serve as a major benchmarking tool both for fundamental research and conservation and is well-developed (I. Biurrun et al. in prep.). In addition, an online reference database is planned for publication along with this study. Finally, the relationship between sampling grain and beta-diversity is now being tested 
Table 6. Distribution of plots in GrassPlot v. 2.00 across the 22 vegetation types and five broad groups. $\mathbf{N}=$ number of independent plots in each vegetation type and broad group; \% GP = proportion of independent plots of each vegetation type in GrassPlot; \% VT = proportion of independent plots of a phytosociological class inside each vegetation type. If the values in $\%$ VT do not sum up to $100 \%$ within one vegetation type, this is due to plots without assignment to a phytosociological class, and also due to the fact that only classes with more than $10 \%$ VT are shown (with some exceptions). [NA] in the column Group indicates the number of plots that have not been assigned to any vegetation type. [NA] in the column Phytosociological class indicates that plots of this vegetation type do not have phytosociological assignment; assignation to vegetation type has been made manually.

\begin{tabular}{|c|c|c|c|c|c|}
\hline Group & Vegetation type & $\mathbf{N}$ & $\%$ GP & Phytosociological class & $\%$ VT \\
\hline \multirow{9}{*}{$\begin{array}{l}\text { Natural grasslands } \\
(N=6,222)\end{array}$} & \multirow{3}{*}{ Alpine grasslands } & \multirow{3}{*}{3,023} & \multirow{3}{*}{10.7} & Elyno-Seslerietea & 12.5 \\
\hline & & & & Festucetea indigestae & 7.3 \\
\hline & & & & Juncetea trifidi & 50.5 \\
\hline & Alpine steppes & 89 & 0.3 & {$[N A]$} & - \\
\hline & \multirow{3}{*}{ Rocky grasslands } & \multirow{3}{*}{948} & \multirow{3}{*}{3.4} & Festuco hystricis-Ononidetea striatae & 24.6 \\
\hline & & & & Festuco-Brometea & 56.6 \\
\hline & & & & Sedo-Scleranthetea & 14.1 \\
\hline & \multirow{2}{*}{ Xeric grasslands and steppes } & \multirow{2}{*}{2,162} & \multirow{2}{*}{7.7} & Cleistogenetea squarrosae & 7.2 \\
\hline & & & & Festuco-Brometea & 67.5 \\
\hline \multirow{6}{*}{$\begin{array}{l}\text { Secondary } \\
\text { grasslands } \\
(N=11,902)\end{array}$} & Wet grasslands & 1,375 & 4.9 & Molinio-Arrhenatheretea & 79.2 \\
\hline & Mesic grasslands & 3,627 & 12.9 & Molinio-Arrhenatheretea & 59.9 \\
\hline & Meso-xeric grasslands & 4,542 & 16.1 & Festuco-Brometea & 96.7 \\
\hline & \multirow{2}{*}{ Mediterranean grasslands } & \multirow{2}{*}{817} & \multirow{2}{*}{2.9} & Lygeo sparti-Stipetea tenacissimae & 18.7 \\
\hline & & & & Stipo-Trachynietea distachyae & 72.7 \\
\hline & Sandy dry grasslands & 1,541 & 5.5 & Koelerio-Corynephoretea canescentis & 88.3 \\
\hline \multirow{9}{*}{$\begin{array}{l}\text { Azonal habitats } \\
(N=7,333)\end{array}$} & \multirow{3}{*}{ Wetlands } & \multirow{3}{*}{2,700} & \multirow{3}{*}{9.6} & Oxycocco-Sphagnetea & 10.9 \\
\hline & & & & Phragmito-Magnocaricetea & 13.2 \\
\hline & & & & Scheuchzerio palustris-Caricetea fuscae & 70.9 \\
\hline & Saline communities & 2,931 & 10.4 & Juncetea maritimi & 70.5 \\
\hline & \multirow{2}{*}{ Dunes } & \multirow{2}{*}{953} & \multirow{2}{*}{3.4} & Ammophiletea & 43.7 \\
\hline & & & & Helichryso-Crucianelletea maritimae & 50.1 \\
\hline & \multirow[t]{2}{*}{ Rocks and screes } & \multirow[t]{2}{*}{356} & \multirow[t]{2}{*}{1.3} & $\begin{array}{l}\text { Didymophyso aucheri-Dracocephaletea } \\
\text { aucheri }\end{array}$ & 22.1 \\
\hline & & & & Thlaspietea rotundifolii & 27.2 \\
\hline & $\begin{array}{l}\text { Saline steppes and semi- } \\
\text { deserts }\end{array}$ & 393 & 1.4 & Festuco-Puccinellietea & 100 \\
\hline \multirow{5}{*}{$\begin{array}{l}\text { Dwarf shrublands } \\
(N=900)\end{array}$} & Arctic-alpine heathlands & 451 & 1.6 & Loiseleurio procumbentis-Vaccinietea & 20.6 \\
\hline & Lowland heathlands & 116 & 0.4 & Calluno-Ulicetea & 31.8 \\
\hline & \multirow{3}{*}{$\begin{array}{l}\text { Garrigues and Thorn cushion } \\
\text { communities }\end{array}$} & \multirow{3}{*}{333} & & Festuco hystricis-Ononidetea striatae & 2.4 \\
\hline & & & 1.2 & Onobrychidetea cornutae & 2.4 \\
\hline & & & & Ononido-Rosmarinetea & 3.6 \\
\hline & & & & Molinio-Arrhenatheretea & 35.4 \\
\hline Tall forb and ruderal & $\begin{array}{l}\text { lall forb and trınge } \\
\text { communities }\end{array}$ & 271 & 1.0 & Mulgedio-Aconitetea & 28.0 \\
\hline communities & & & & Trifolio-Geranietea sanguinei & 26.9 \\
\hline$(N=724)$ & Ruderal communities & 453 & 16 & Artemisietea vulgaris & 18.9 \\
\hline & 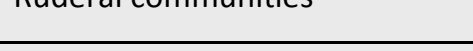 & كנד & 1.0 & Epilobietea angustifolii & 34.4 \\
\hline Deserts and semi- & Alpine deserts & 11 & $<0.1$ & Ajanio-Cleistogenetea songoricae & 72.7 \\
\hline deserts & Cold deserts and semi-deserts & 519 & 1.8 & {$[N A]$} & - \\
\hline$(N=559)$ & Warm deserts and semi-deserts & 29 & 0.1 & Kleinio-Euphorbietea canariensis & 44.8 \\
\hline [NA] & - & 531 & 1.9 & & \\
\hline
\end{tabular}


Table 7. Number of plots $(N)$, mean richness $\left(S_{\text {mean }}\right)$ with standard deviation $\left(S_{S D}\right)$ and maximum richness $\left(S_{\text {max }}\right)$ in GrassPlot v. 2.00 across different plot sizes, and for vascular plants and complete terricolous vegetation (vascular plants, bryophytes and lichens), respectively. All plots and subplots have been considered, thus a total of 190,673 plots. Nonstandard plot sizes include all other plot sizes (which are collected only in case of nested-plot series). Note that due to different sample sizes (see column $\mathbf{N}$ ), maxima of larger plot sizes can be lower than for maxima of smaller plot sizes or that maxima of complete terricolous vegetation can be lower than maxima of vascular plants only. Information on plot sizes that deviate by a maximum of $10 \%$ (e.g. $9 \mathrm{~m}^{2}$ vs. $10 \mathrm{~m}^{2}$ ), is combined in one row because, based on species-area relationships with typical $z$-values between 0.15 and 0.30 , the relative difference in richness would only be about $1.6-$ $3.2 \%$, i.e. negligible given the overall variability of the data.

\begin{tabular}{|c|c|c|c|c|c|c|c|c|}
\hline \multicolumn{5}{|c|}{ Vascular plants } & \multicolumn{4}{|c|}{ Complete terricolous vegetation } \\
\hline Plot size $\left(m^{2}\right)$ & $N$ & $S_{\text {mean }}$ & $S_{S D}$ & $S_{\max }$ & $N$ & $S_{\text {mean }}$ & $S_{S D}$ & $S_{\max }$ \\
\hline 0.0001 & 2,534 & 1.9 & 1.6 & 11 & 1,797 & 2.1 & 1.7 & 10 \\
\hline 0.001 or 0.0009 & 3,838 & 3.3 & 2.1 & 19 & 1,738 & 3.5 & 13.4 & 19 \\
\hline 0.01 & 69,525 & 3.9 & 17.0 & 24 & 2,491 & 6.6 & 20.5 & 29 \\
\hline 0.1 or 0.09 & 4,963 & 11.3 & 30.4 & 43 & 1,763 & 11.1 & 32.5 & 46 \\
\hline 1 & 22,121 & 13.9 & 55.9 & 79 & 2,672 & 18.6 & 58.0 & 82 \\
\hline 10 or 9 & 9,964 & 27.6 & 75.0 & 106 & 2,617 & 34.5 & 71.4 & 101 \\
\hline 100 & 4,634 & 29.6 & 89.1 & 127 & 962 & 48.5 & 94.0 & 134 \\
\hline 1,000 or 900 or 1,024 & 187 & 48.0 & 17.7 & 134 & 45 & 59.0 & 85.6 & 123 \\
\hline Non-standard plot sizes & 72,907 & & & & 2,430 & & & \\
\hline Total & 190,673 & & & & 16,515 & & & \\
\hline
\end{tabular}

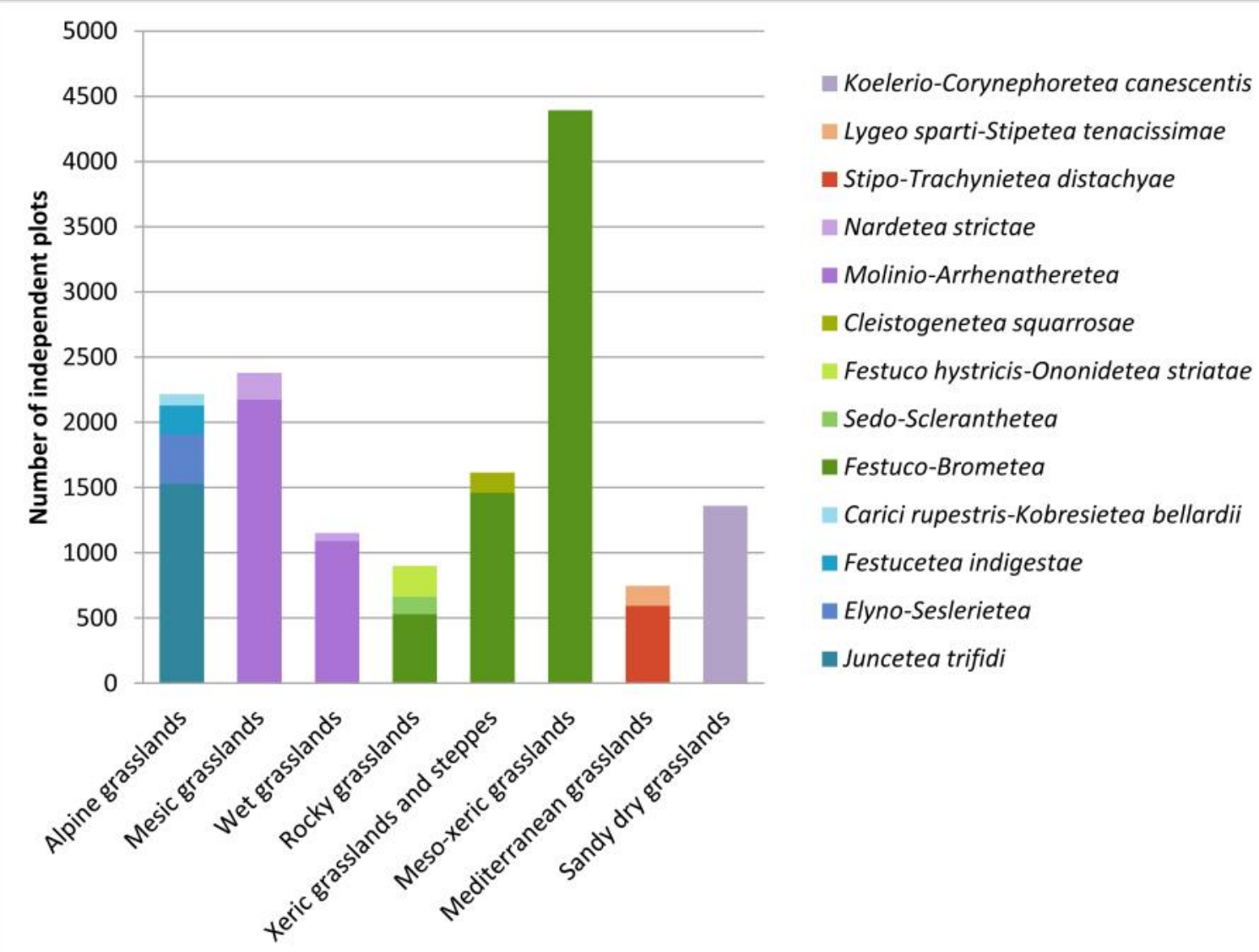

Fig. 4. Frequency of the natural and secondary grassland types and their assignment to phytosociological classes in GrassPlot v. 2.00. Alpine steppes are not represented as they are not assigned to any phytosociological class in GrassPlot. Only independent plots have been considered $(N=\mathbf{2 8 , 1 7 1})$. Absolute numbers are shown, so that the presence of each class in different vegetation types can be compared. 


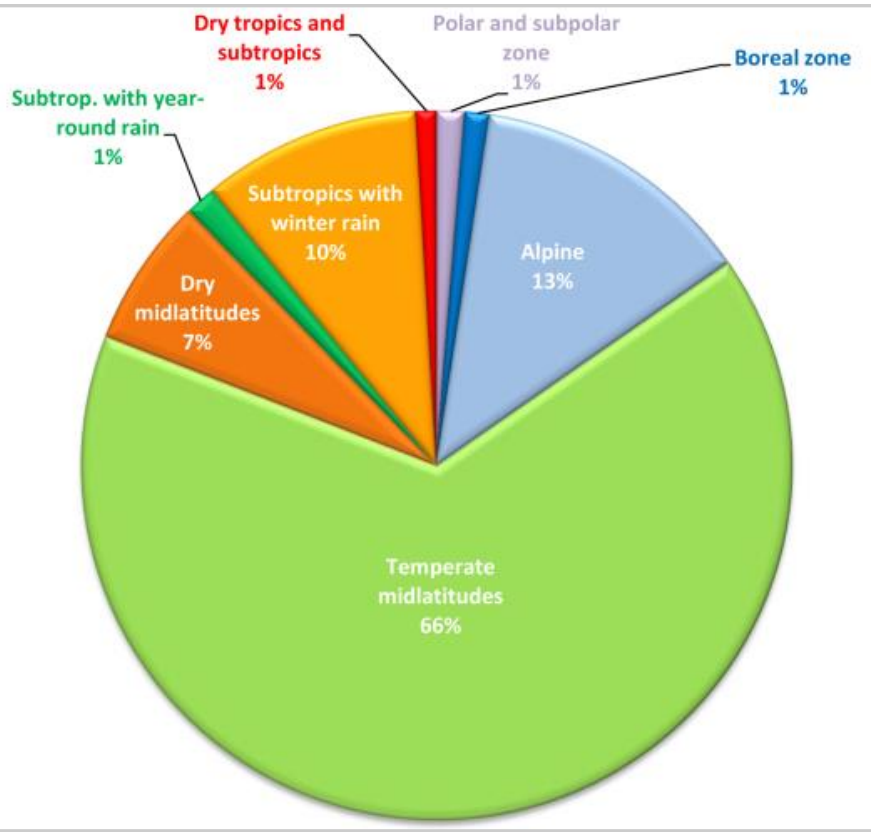

Fig. 5. Distribution of independent plots contained in GrassPlot v. $2.00(N=28,171)$ across biomes as defined by Bruelheide et al. (2019).

across different spatial extents and vegetation types based on composition data (S. Burrascano et al. in prep.).

GrassPlot represents work in progress. Therefore, we welcome new data contributions that meet the specific criteria of GrassPlot (Dengler et al. 2018; GrassPlot website, http:// bit.ly/2NZ6A9d). Of particular value are datasets that (largely) follow the standardised EDGG multi-scale sampling (Dengler et al. 2016b), specifically if they come from underrepresented regions or vegetation types (see Figs. 2 and 3, Table 6). However, as GrassPlot does not have external funding, data preparation and harmonisation has to be undertaken voluntarily by the Governing Board and other members and thus it might take a while from data provision to actual inclusion. Likewise, we are also working on improving the completeness and consistency of the header data (methodological, geographic, abiotic, land use, structural information) of the contained plots and increasing the fraction of plots with readily available compositional data. We have agreed with the European Vegetation Archive (EVA; Chytrý et al. 2016) and the global vegetation database "sPlot" (Bruelheide et al. 2019) to contribute GrassPlot data not yet included in these two databases once the compositional data are ready and provided the data owners contribute. This step will fill important data gaps in EVA and sPlot and give our data contributors the opportunity of additional benefit. Last but not least, we hope that the publication of the first macroecological paper from GrassPlot (Dengler et al. 2019) will raise the awareness of the unique qualities of GrassPlot for such studies and spur many more exciting research proposals to be submitted to the Governing Board.
Table 8. Distribution of independent plots in GrassPlot v. 2.00 according to the regionalization used in Grasslands of the world (Törok \& Dengler 2018) and Encyclopedia of the world's biomes (Dengler et al. in press).

\begin{tabular}{lll}
\hline Grasslands of the world & $N$ & $\%$ \\
\hline Western and Northern Europe & 13,343 & 47.4 \\
\hline Eastern Europe & 6,598 & 23.4 \\
\hline Mediterranean and Middle East & 5,301 & 18.8 \\
\hline China and Mongolia & 1,762 & 6.3 \\
\hline Russia & 522 & 1.9 \\
\hline Japan & 418 & 1.5 \\
\hline Kazakhstan and Middle Asia & 227 & 0.8 \\
\hline Encyclopedia of the world's biomes & $N$ & $\%$ \\
\hline Western Europe & 14,042 & 49.8 \\
\hline Eastern Europe & 5,455 & 19.4 \\
\hline Northern Europe & 3,281 & 11.6 \\
Mediterranean & 1,779 & 6.3 \\
\hline China & 1,291 & 4.6 \\
\hline Middle East and Caucasus & 685 & 2.4 \\
\hline Russia & 522 & 1.9 \\
\hline Mongolia & 471 & 1.7 \\
\hline Japan and Korea & 418 & 1.5 \\
\hline Kazakhstan and Middle Asia & 227 & 0.8 \\
\hline
\end{tabular}

\section{Author contributions}

I.B. is the database manager of GrassPlot; she and J.D. planned and led this paper. S.B., I.D., R.G., J.K. and R.P. as further members of the GrassPlot Governing Board as well as I.G.M., V.W., S.P., A.M., V.P, C.M. and A.N. contributed substantially to data preparation, analyses and writting. A.B., S.Bo., A.M.C. J.A.G., A.K., J.A.C., B.E., B.J.A., Z.K., M.M., G.S and K.M added helpful comments, and all other authors contributed data to GrassPlot after v. 1.00, checked and approved the manuscript.

\section{Acknowledgements}

We thank the BaylntAn program of the Bavarian Research Alliance (https://www.bayfor.org/en/research-funding/ bayintan.php; grant no. UBT 2017 58) and the Bayreuth Centre of Ecology and Environmental Research (BayCEER; https://www.bayceer.uni-bayreuth.de/) for funding the GrassPlot workshop in Bayreuth. We thank EDGG and the International Association for Vegetation Science (IAVS) for the continuous support of the EDGG Field Workshops during which large parts of the GrassPlot data were sampled. We are also grateful to the scientific editor Frank Yonghong Li and the linguistic editor Richard Jefferson.

\section{References}

Bruelheide, H., Dengler, J., Jiménez-Alfaro, B., Purschke, O., Hennekens, S.M., Chytrý M., Pillar, V.D., Jansen, F., Kattge, J., (...) \& Zverev, A. 2019. sPlot - a new tool for global vegetation analyses. Journal of Vegetation Science 30: 161-186.

Cancellieri, L., Mancini, L.D., Sperandii, M.G. \& Filibeck, G. 2017. In and out: Effects of shoot- vs. rooted-presence sampling meth- 
ods on plant diversity measures in mountain grasslands. Ecological Indicators 72: 315-321.

Cayuela, L, Granzow-de la Cerda, I., Albuquerque, F.S. \& Golicher, D. 2012. Taxondstand: An R package for species names standardisation in vegetation databases. Methods in Ecology and Evolution 3: 1078-1083.

Chytrý, M., Hennekens, S.M., Jiménez-Alfaro, B., Knollová, I., Dengler, J., Jansen, F., Landucci, F., Schaminée, J.H.G, Aćić, S., (...) \& Yamalov, S. 2016. European Vegetation Archive (EVA): an integrated database of European vegetation plots. Applied Vegetation Science 19: 173-180.

Collins, S.L., Knapp, A.K., Briggs, J.M., Blair, J.M. \& Steinauer, E.M. 1998. Modulation of diversity by grazing and mowing in native tallgrass prairie. Science 280: 745-747.

Dengler, J. 2008. Pitfalls in small-scale species-area sampling and analysis. Folia Geobotanica 43: 269-287.

Dengler, J., Jansen, F., Glöckler, F., Peet, R.K., De Cáceres, M., Chytrý, M., Ewald, J., Oldeland, J., Finckh, M., (...) \& Spencer, N. 2011. The Global Index of Vegetation-Plot Databases (GIVD): a new resource for vegetation science. Journal of Vegetation Science 22: 582-597.

Dengler, J., Todorova, S., Becker, T., Boch, S., Chytrý, M., Diekmann, M., Dolnik, C., Dupré, C., Giusso del Galdo, G.P., (...) \& Vassilev, K. 2012. Database Species-Area Relationships in Palaearctic Grasslands. Biodiversity \& Ecology 4: 321-322.

Dengler, J., Biurrun, I., Apostolova, I., Baumann, E., Becker, T., Berastegi, A., Boch, S., Dembicz, I., Dolnik, C., (...) \& Weiser, F. 2016a. Scale-dependent plant diversity in Palaearctic grasslands: a comparative overview. Bulletin of the Eurasian Dry Grassland Group 31: 12-26.

Dengler, J., Boch, S., Filibeck, G., Chiarucci, A., Dembicz, I., Guarino, R., Henneberg, B., Janišová, M., Marcenò, C., (...) \& Biurrun, I. 2016b. Assessing plant diversity and composition in grasslands across spatial scales: the standardised EDGG sampling methodology. Bulletin of the Eurasian Grassland Group 32: 13-30.

Dengler, J., Wagner, V., Dembicz, I., García-Mijangos, I., Naqinezhad, A., Boch, S., Chiarucci, A., Conradi, T., Filibeck, G., (...) \& Biurrun, I. 2018. GrassPlot - a database of multi-scale plant diversity in Palaearctic grasslands. Phytocoenologia 48: 331-347.

Dengler, J., Matthews, T.J., Steinbauer, M.J., Wolfrum, S., Boch, S., Chiarucci, A., Conradi, T., Dembicz, I., Marcenò, C., (...) \& Biurrun, I. 2019. Species-area relationships in continuous vegetation: Evidence from Palaearctic grasslands. Journal of Biogeography. DOI: 10.1111/jbi.13697.

Dengler, J., Biurrun, I., Boch, S., Dembicz, I. \& Török, P. in press. Grasslands of the Palaeartic realm: introduction and synthesis. In: Goldstein, M.I. \& DellaSala, D.A. (eds.) Encyclopedia of the World's biomes. Elsevier, Oxford, UK.

Ermakov, N. \& Krestov, P. 2009. Revision of the higher syntaxa of meadows in the Russian far east. Vegetation of Russia 14. St. Petersburg, Russia.

Ermakov, N., Larionov, A., Polyakova, M., Pestunov, I. \& Didukh. Y.P. 2014. Diversity and spatial structure of cryophitic steppes of the Minusinskaya intermountain basin in Southern Siberia (Russia). Tuexenia 34: 431-446.

Güler, B., Jentsch, A., Bartha, S., Bloor, J.M.G., Campetella, G., Canullo, R., Házi, J., Kreyling, J., Pottier, J., (...) \& Dengler, J. 2016. How plot shape and dispersion affect plant species richness counts: implications for sampling design and rarefaction analyses. Journal of Vegetation Science 27: 692-703.

Hudson, L.N., Newbold, T., Contu, S., Hill, S.L.L., Lysenko, I., De Palma, A., Phillips, H.R.P., Senior, R.A., Bennett, D.J., (...) \& Pur- vis, A. 2014. The PREDICTS database: A global database of how local terrestrial biodiversity responds to human impacts. Ecology and Evolution 4: 4701-4735.

Hüseynova, R. \& Yalçin, E. 2018. Subalpine vegetation in Giresun Mountains (Turkey). Acta Botanica Croatica 77: 152-160.

Kuzemko, A.A., Steinbauer, M.J., Becker, T., Didukh, Y.P., Dolnik, C., Jeschke, M., Naqinezhad, A., Ugurlu, E., Vassilev, K. \& Dengler, J. 2016. Patterns and drivers of phytodiversity of steppe grasslands of Central Podolia (Ukraine). Biodiversity and Conservation 25: 2233-2250.

Mucina, L., Bültmann, H., Dierßen, K., Theurillat, J.-P., Raus, T., Čarni, A., Šumberová, K., Willner, W., Dengler, J., (...) \& Tichý, L. 2016. Vegetation of Europe: Hierarchical floristic classification system of vascular plant, bryophyte, lichen, and algal communities. Applied Vegetation Science 19 (Suppl. 1): 3-264.

Niedrist, G., Tasser, E., Lüth, C., Dalla Via, J. \& Tappeiner, U. 2009. Plant diversity declines with recent land use changes in European Alps. Plant Ecology 202: 195-210.

Noroozi, J., Willner, W., Pauli, H. \& Grabherr, G. 2014. Phytosociology and ecology of the high-alpine to subnival scree vegetation of N and NW Iran (Alborz and Azerbaijan Mts.). Applied Vegetation Science 17: 142-161.

Nowak, A., Nobis, A., Nowak, S. \& Nobis, M. 2018. Classification of steppe vegetation in the eastern Pamir Alai and southwestern Tian-Shan Mountains (Tajikistan, Kyrgyzstan). Phytocoenologia 48: 369-391.

Pauli, H., Gottfried, M., Dullinger, S., Abdaladze, O., Akhalkatsi, M., Benito Alonso, J.L., Coldea, G., Dick, J., Erschbamer, B., (...) \& Grabherr, G. 2012. Recent plant diversity changes on Europe's mountain summits. Science 336: 353-355.

Polyakova, M.A., Dembicz, I., Becker, T., Becker, U., Demina, O.N., Ermakov, N., Filibeck, G., Guarino, R., Janišová, M., (...) \& Dengler, J. 2016. Scale- and taxon-dependent patterns of plant diversity in steppes of Khakassia, South Siberia (Russia). Biodiversity and Conservation 25: 2251-2273.

$\mathrm{R}$ Core Team. 2019. $R$ : A language and environment for statistical computing. R Foundation for Statistical Computing. Vienna, AT.

Reinecke, J., Troeva, E. \& Wesche, K. 2017. Extrazonal steppes and other temperate grasslands of northern Siberia - Phytosociological classification and ecological characterization. Phytocoenologia 47: 167-196.

Schultz, J. 2005. The ecozones of the world. The ecological division of the geosphere. $2^{\text {nd }}$ ed. Springer, Berlin, DE.

Török, P. \& Dengler, J. 2018. Palaearctic grasslands in transition: overarching patterns and future prospects. In: Squires, V.R., Dengler, J., Feng, H. \& Hua, L. (eds.) Grasslands of the world: diversity, management and conservation: pp. 15-26. CRC Press, Boca Raton, US.

Turtureanu, P.D., Palpurina, S., Becker, T., Dolnik, C., Ruprecht, E., Sutcliffe, L.M.E., Szabó, A. \& Dengler, J. 2014. Scale- and taxondependent biodiversity patterns of dry grassland vegetation in Transylvania (Romania). Agriculture, Ecosystems \& Environment 182: 15-24.

Wehrden, H. von, Wesche, K. \& Miehe, G. 2009. Plant communities of the southern Mongolian Gobi. Phytocoenologia 39: 331-376.

Wickham, H. \& Henry, L. 2019. tidyr: Easily Tidy Data with 'spread ()' and 'gather()' Functions. R package version 0.8.3. https:// CRAN.R-project.org/package $=$ tidyr.

Wickham, H., Francois, R., Henry, L. \& Müller, K. 2017. dplyr: A Grammar of Data Manipulation. R package version 0.7.4. https://CRAN.R-project.org/package=dplyr. 
Appendix 1. Example of species composition in a nested-plot series prepared in long format in GrassPlot v. 2.00.

\begin{tabular}{|c|c|c|c|c|c|c|c|}
\hline GrassPlot.plotID & Area.m2 & $\begin{array}{l}\text { GrassPlot.ID.largest. } \\
\text { nested }\end{array}$ & Species.original & Group & Layer & Abundance & $\begin{array}{l}\text { Abundance_ } \\
\text { Scale }\end{array}$ \\
\hline EU_F_N001_0.0001aa & 0.0001 & EU_F_N001_100 & $\begin{array}{l}\text { Eryngium } \\
\text { maritimum }\end{array}$ & $\mathrm{V}$ & $\mathrm{H}$ & 1 & $\mathrm{P} / \mathrm{A}$ \\
\hline EU_F_N001_0.0001ab & 0.0001 & EU_F_N001_100 & $\begin{array}{l}\text { Ammophila } \\
\text { arenaria subsp. } \\
\text { australis }\end{array}$ & V & $\mathrm{H}$ & 1 & $\mathrm{P} / \mathrm{A}$ \\
\hline EU_F_N001_0.0001ab & 0.0001 & EU_F_N001_100 & $\begin{array}{l}\text { Calystegia } \\
\text { soldanella }\end{array}$ & V & $\mathrm{H}$ & 1 & $\mathrm{P} / \mathrm{A}$ \\
\hline EU_F_N001_0.0001bb & 0.0001 & EU_F_N001_100 & $\begin{array}{l}\text { Calystegia } \\
\text { soldanella }\end{array}$ & V & $\mathrm{H}$ & 1 & $\mathrm{P} / \mathrm{A}$ \\
\hline EU_F_N001_0.001aa & 0.001 & EU_F_N001_100 & $\begin{array}{l}\text { Eryngium } \\
\text { maritimum }\end{array}$ & V & $\mathrm{H}$ & 1 & $\mathrm{P} / \mathrm{A}$ \\
\hline EU_F_N001_0.001ab & 0.001 & EU_F_N001_100 & $\begin{array}{l}\text { Ammophila } \\
\text { arenaria subsp. } \\
\text { australis }\end{array}$ & V & $\mathrm{H}$ & 1 & $P / A$ \\
\hline EU_F_N001_0.001ab & 0.001 & EU_F_N001_100 & $\begin{array}{l}\text { Calystegia } \\
\text { soldanella }\end{array}$ & $\mathrm{V}$ & $\mathrm{H}$ & 1 & $\mathrm{P} / \mathrm{A}$ \\
\hline EU_F_N001_0.001bb & 0.001 & EU_F_N001_100 & $\begin{array}{l}\text { Calystegia } \\
\text { soldanella }\end{array}$ & $\mathrm{V}$ & $\mathrm{H}$ & 1 & $\mathrm{P} / \mathrm{A}$ \\
\hline EU_F_N001_0.01aa & 0.01 & EU_F_N001_100 & $\begin{array}{l}\text { Eryngium } \\
\text { maritimum } \\
\end{array}$ & V & $\mathrm{H}$ & 1 & $\mathrm{P} / \mathrm{A}$ \\
\hline EU_F_N001_0.01ab & 0.01 & EU_F_N001_100 & $\begin{array}{l}\text { Ammophila } \\
\text { arenaria subsp. } \\
\text { australis }\end{array}$ & $\mathrm{V}$ & $\mathrm{H}$ & 1 & $\mathrm{P} / \mathrm{A}$ \\
\hline EU_F_N001_0.01ab & 0.01 & EU_F_N001_100 & $\begin{array}{l}\text { Calystegia } \\
\text { soldanella }\end{array}$ & $\mathrm{V}$ & $\mathrm{H}$ & 1 & $\mathrm{P} / \mathrm{A}$ \\
\hline EU_F_N001_0.01ab & 0.01 & EU_F_N001_100 & $\begin{array}{l}\text { Euphorbia } \\
\text { paralias }\end{array}$ & $\mathrm{V}$ & $\mathrm{H}$ & 1 & $\mathrm{P} / \mathrm{A}$ \\
\hline EU_F_N001_0.01ba & 0.01 & EU_F_N001_100 & $\begin{array}{l}\text { Galium } \\
\text { arenarium }\end{array}$ & $\mathrm{V}$ & $\mathrm{H}$ & 1 & $\mathrm{P} / \mathrm{A}$ \\
\hline EU_F_N001_0.01bb & 0.01 & EU_F_N001_100 & $\begin{array}{l}\text { Calystegia } \\
\text { soldanella }\end{array}$ & $\mathrm{V}$ & $\mathrm{H}$ & 1 & $\mathrm{P} / \mathrm{A}$ \\
\hline EU_F_N001_0.1aa & 0.1 & EU_F_N001_100 & $\begin{array}{l}\text { Calystegia } \\
\text { soldanella } \\
\end{array}$ & $\mathrm{V}$ & $\mathrm{H}$ & 1 & $\mathrm{P} / \mathrm{A}$ \\
\hline EU_F_N001_0.1aa & 0.1 & EU_F_N001_100 & $\begin{array}{l}\text { Elytrigia juncea } \\
\text { subsp. } \\
\text { boreoatlantica }\end{array}$ & $\mathrm{V}$ & $\mathrm{H}$ & 1 & $\mathrm{P} / \mathrm{A}$ \\
\hline EU_F_N001_0.1aa & 0.1 & EU_F_N001_100 & $\begin{array}{l}\text { Eryngium } \\
\text { maritimum } \\
\end{array}$ & $\mathrm{V}$ & $\mathrm{H}$ & 1 & $\mathrm{P} / \mathrm{A}$ \\
\hline EU_F_N001_0.1ab & 0.1 & EU_F_N001_100 & $\begin{array}{l}\text { Ammophila } \\
\text { arenaria subsp. } \\
\text { australis }\end{array}$ & $\mathrm{V}$ & $\mathrm{H}$ & 1 & $\mathrm{P} / \mathrm{A}$ \\
\hline EU_F_N001_0.1ab & 0.1 & EU_F_N001_100 & $\begin{array}{l}\text { Calystegia } \\
\text { soldanella }\end{array}$ & V & $\mathrm{H}$ & 1 & $P / A$ \\
\hline EU_F_N001_0.1ab & 0.1 & EU_F_N001_100 & $\begin{array}{l}\text { Eryngium } \\
\text { maritimum }\end{array}$ & $\mathrm{V}$ & $\mathrm{H}$ & 1 & $\mathrm{P} / \mathrm{A}$ \\
\hline EU_F_N001_0.1ab & 0.1 & EU_F_N001_100 & $\begin{array}{l}\text { Euphorbia } \\
\text { paralias }\end{array}$ & $\mathrm{V}$ & $\mathrm{H}$ & 1 & $P / A$ \\
\hline EU_F_N001_0.1ab & 0.1 & EU_F_N001_100 & $\begin{array}{l}\text { Hieracium } \\
\text { eriophorum }\end{array}$ & $\mathrm{V}$ & $\mathrm{H}$ & 1 & $\mathrm{P} / \mathrm{A}$ \\
\hline EU_F_N001_0.1ba & 0.1 & EU_F_N001_100 & $\begin{array}{l}\text { Ammophila } \\
\text { arenaria subsp. } \\
\text { australis }\end{array}$ & V & $\mathrm{H}$ & 1 & $\mathrm{P} / \mathrm{A}$ \\
\hline
\end{tabular}


Appendix 1. Continuation.

\begin{tabular}{|c|c|c|c|c|c|c|c|}
\hline GrassPlot.plotID & Area.m2 & $\begin{array}{l}\text { GrassPlot.ID.larges } \\
\text { t.nested }\end{array}$ & Species.original & Group & Layer & Abundance & $\begin{array}{l}\text { Abundance_ } \\
\text { Scale }\end{array}$ \\
\hline EU_F_N001_0.1ba & 0.1 & EU_F_N001_100 & $\begin{array}{l}\text { Calystegia } \\
\text { soldanella }\end{array}$ & $\mathrm{V}$ & $\mathrm{H}$ & 1 & $\mathrm{P} / \mathrm{A}$ \\
\hline EU_F_N001_0.1ba & 0.1 & EU_F_N001_100 & $\begin{array}{l}\text { Eryngium } \\
\text { maritimum }\end{array}$ & $\mathrm{V}$ & $\mathrm{H}$ & 1 & $P / A$ \\
\hline EU_F_N001_0.1ba & 0.1 & EU_F_N001_100 & Galium arenarium & $\mathrm{V}$ & $\mathrm{H}$ & 1 & $\mathrm{P} / \mathrm{A}$ \\
\hline EU_F_N001_0.1bb & 0.1 & EU_F_N001_100 & $\begin{array}{l}\text { Calystegia } \\
\text { soldanella }\end{array}$ & $\mathrm{V}$ & $\mathrm{H}$ & 1 & $P / A$ \\
\hline EU_F_N001_0.1bb & 0.1 & EU_F_N001_100 & $\begin{array}{l}\text { Elytrigia juncea } \\
\text { subsp. } \\
\text { boreoatlantica }\end{array}$ & $\mathrm{V}$ & $\mathrm{H}$ & 1 & $\mathrm{P} / \mathrm{A}$ \\
\hline EU_F_N001_100 & 100 & EU_F_N001_100 & $\begin{array}{l}\text { Ammophila } \\
\text { arenaria subsp. } \\
\text { australis }\end{array}$ & $\mathrm{V}$ & $\mathrm{H}$ & 1 & $P / A$ \\
\hline EU_F_N001_100 & 100 & EU_F_N001_100 & $\begin{array}{l}\text { Calystegia } \\
\text { soldanella }\end{array}$ & V & $\mathrm{H}$ & 1 & $\mathrm{P} / \mathrm{A}$ \\
\hline EU_F_N001_100 & 100 & EU_F_N001_100 & $\begin{array}{l}\text { Elytrigia juncea } \\
\text { subsp. } \\
\text { boreoatlantica }\end{array}$ & V & $\mathrm{H}$ & 1 & $P / A$ \\
\hline EU_F_N001_100 & 100 & EU_F_N001_100 & $\begin{array}{l}\text { Eryngium } \\
\text { maritimum }\end{array}$ & V & $\mathrm{H}$ & 1 & $P / A$ \\
\hline EU_F_N001_100 & 100 & EU_F_N001_100 & Euphorbia paralias & $\mathrm{V}$ & $\mathrm{H}$ & 1 & $\mathrm{P} / \mathrm{A}$ \\
\hline EU_F_N001_100 & 100 & EU_F_N001_100 & Galium arenarium & $\mathrm{V}$ & $\mathrm{H}$ & 1 & $\mathrm{P} / \mathrm{A}$ \\
\hline EU_F_N001_100 & 100 & EU_F_N001_100 & $\begin{array}{l}\text { Hieracium } \\
\text { eriophorum }\end{array}$ & $\mathrm{V}$ & $\mathrm{H}$ & 1 & $P / A$ \\
\hline EU_F_N001_100 & 100 & EU_F_N001_100 & $\begin{array}{l}\text { Leontodon saxatilis } \\
\text { subsp. saxatilis }\end{array}$ & $\mathrm{V}$ & $\mathrm{H}$ & 1 & $P / A$ \\
\hline EU_F_N001_10a & 10 & EU_F_N001_100 & $\begin{array}{l}\text { Ammophila } \\
\text { arenaria subsp. } \\
\text { australis }\end{array}$ & V & $\mathrm{H}$ & 5 & Cover \\
\hline EU_F_N001_10a & 10 & EU_F_N001_100 & $\begin{array}{l}\text { Calystegia } \\
\text { soldanella }\end{array}$ & V & $\mathrm{H}$ & 10 & Cover \\
\hline EU_F_N001_10a & 10 & EU_F_N001_100 & $\begin{array}{l}\text { Elytrigia juncea } \\
\text { subsp. } \\
\text { boreoatlantica }\end{array}$ & $\mathrm{V}$ & $\mathrm{H}$ & 20 & Cover \\
\hline EU_F_N001_10a & 10 & EU_F_N001_100 & $\begin{array}{l}\text { Eryngium } \\
\text { maritimum }\end{array}$ & $\mathrm{V}$ & $\mathrm{H}$ & 10 & Cover \\
\hline EU_F_N001_10a & 10 & EU_F_N001_100 & Euphorbia paralias & $\mathrm{V}$ & $\mathrm{H}$ & 2.5 & Cover \\
\hline EU_F_N001_10a & 10 & EU_F_N001_100 & $\begin{array}{l}\text { Hieracium } \\
\text { eriophorum }\end{array}$ & $\mathrm{V}$ & $\mathrm{H}$ & 2.5 & Cover \\
\hline EU_F_N001_10b & 10 & EU_F_N001_100 & $\begin{array}{l}\text { Ammophila } \\
\text { arenaria subsp. } \\
\text { australis }\end{array}$ & $\mathrm{V}$ & $\mathrm{H}$ & 5 & Cover \\
\hline EU_F_N001_10b & 10 & EU_F_N001_100 & $\begin{array}{l}\text { Calystegia } \\
\text { soldanella }\end{array}$ & $\mathrm{V}$ & $\mathrm{H}$ & 2.5 & Cover \\
\hline EU_F_N001_10b & 10 & EU_F_N001_100 & $\begin{array}{l}\text { Elytrigia juncea } \\
\text { subsp. } \\
\text { boreoatlantica }\end{array}$ & V & $\mathrm{H}$ & 10 & Cover \\
\hline EU_F_N001_10b & 10 & EU_F_N001_100 & $\begin{array}{l}\text { Eryngium } \\
\text { maritimum }\end{array}$ & $\mathrm{V}$ & $\mathrm{H}$ & 10 & Cover \\
\hline EU_F_N001_10b & 10 & EU_F_N001_100 & Euphorbia paralias & $\mathrm{V}$ & $\mathrm{H}$ & 2.5 & Cover \\
\hline EU_F_N001_10b & 10 & EU_F_N001_100 & Galium arenarium & $\mathrm{V}$ & $\mathrm{H}$ & 5 & Cover \\
\hline EU_F_N001_10b & 10 & EU_F_N001_100 & $\begin{array}{l}\text { Hieracium } \\
\text { eriophorum }\end{array}$ & $\mathrm{V}$ & $\mathrm{H}$ & 2.5 & Cover \\
\hline
\end{tabular}


Appendix 1. Continuation.

\begin{tabular}{|c|c|c|c|c|c|c|c|}
\hline GrassPlot.plotID & Area.m2 & $\begin{array}{l}\text { GrassPlot.ID.larges } \\
\text { t.nested }\end{array}$ & Species.original & Group & Layer & Abundance & $\begin{array}{l}\text { Abundance_ } \\
\text { Scale }\end{array}$ \\
\hline EU_F_N001_10b & 10 & EU_F_N001_100 & $\begin{array}{l}\text { Leontodon } \\
\text { saxatilis subsp. } \\
\text { saxatilis }\end{array}$ & V & $\mathrm{H}$ & 2.5 & Cover \\
\hline EU_F_N001_1aa & 1 & EU_F_N001_100 & $\begin{array}{l}\text { Calystegia } \\
\text { soldanella }\end{array}$ & $\mathrm{V}$ & $\mathrm{H}$ & 4 & Cover \\
\hline EU_F_N001_1aa & 1 & EU_F_N001_100 & $\begin{array}{l}\text { Elytrigia juncea } \\
\text { subsp. } \\
\text { boreoatlantica }\end{array}$ & $\mathrm{V}$ & $\mathrm{H}$ & 12 & Cover \\
\hline EU_F_N001_1aa & 1 & EU_F_N001_100 & $\begin{array}{l}\text { Eryngium } \\
\text { maritimum }\end{array}$ & $\mathrm{V}$ & $\mathrm{H}$ & 8 & Cover \\
\hline EU_F_N001_1aa & 1 & EU_F_N001_100 & $\begin{array}{l}\text { Euphorbia } \\
\text { paralias }\end{array}$ & V & $\mathrm{H}$ & 8 & Cover \\
\hline EU_F_N001_1aa & 1 & EU_F_N001_100 & $\begin{array}{l}\text { Hieracium } \\
\text { eriophorum }\end{array}$ & V & $\mathrm{H}$ & 1 & Cover \\
\hline EU_F_N001_1ab & 1 & EU_F_N001_100 & $\begin{array}{l}\text { Ammophila } \\
\text { arenaria subsp. } \\
\text { australis }\end{array}$ & V & $\mathrm{H}$ & 35 & Cover \\
\hline EU_F_N001_1ab & 1 & EU_F_N001_100 & $\begin{array}{l}\text { Calystegia } \\
\text { soldanella }\end{array}$ & V & $\mathrm{H}$ & 6 & Cover \\
\hline EU_F_N001_1ab & 1 & EU_F_N001_100 & $\begin{array}{l}\text { Elytrigia juncea } \\
\text { subsp. } \\
\text { boreoatlantica }\end{array}$ & V & $\mathrm{H}$ & 4 & Cover \\
\hline EU_F_N001_1ab & 1 & EU_F_N001_100 & $\begin{array}{l}\text { Eryngium } \\
\text { maritimum }\end{array}$ & V & $\mathrm{H}$ & 4 & Cover \\
\hline EU_F_N001_1ab & 1 & EU_F_N001_100 & $\begin{array}{l}\text { Euphorbia } \\
\text { paralias }\end{array}$ & $\mathrm{V}$ & $\mathrm{H}$ & 2 & Cover \\
\hline EU_F_N001_1ab & 1 & EU_F_N001_100 & $\begin{array}{l}\text { Hieracium } \\
\text { eriophorum }\end{array}$ & V & $\mathrm{H}$ & 1 & Cover \\
\hline EU_F_N001_1ba & 1 & EU_F_N001_100 & $\begin{array}{l}\text { Ammophila } \\
\text { arenaria subsp. } \\
\text { australis }\end{array}$ & $\mathrm{V}$ & $\mathrm{H}$ & 10 & Cover \\
\hline EU_F_N001_1ba & 1 & EU_F_N001_100 & $\begin{array}{l}\text { Calystegia } \\
\text { soldanella }\end{array}$ & $\mathrm{V}$ & $\mathrm{H}$ & 6 & Cover \\
\hline EU_F_N001_1ba & 1 & EU_F_N001_100 & $\begin{array}{l}\text { Eryngium } \\
\text { maritimum }\end{array}$ & V & $\mathrm{H}$ & 8 & Cover \\
\hline EU_F_N001_1ba & 1 & EU_F_N001_100 & Galium arenarium & $\mathrm{V}$ & $\mathrm{H}$ & 20 & Cover \\
\hline EU_F_N001_1ba & 1 & EU_F_N001_100 & $\begin{array}{l}\text { Leontodon } \\
\text { saxatilis subsp. } \\
\text { saxatilis }\end{array}$ & $\mathrm{V}$ & $\mathrm{H}$ & 1 & Cover \\
\hline EU_F_N001_1bb & 1 & EU_F_N001_100 & $\begin{array}{l}\text { Calystegia } \\
\text { soldanella } \\
\end{array}$ & V & $\mathrm{H}$ & 3 & Cover \\
\hline EU_F_N001_1bb & 1 & EU_F_N001_100 & $\begin{array}{l}\text { Elytrigia juncea } \\
\text { subsp. } \\
\text { boreoatlantica }\end{array}$ & $\mathrm{V}$ & $\mathrm{H}$ & 5 & Cover \\
\hline EU_F_N001_1bb & 1 & EU_F_N001_100 & $\begin{array}{l}\text { Eryngium } \\
\text { maritimum }\end{array}$ & $\mathrm{V}$ & $\mathrm{H}$ & 1 & Cover \\
\hline EU_F_N001_1bb & 1 & EU_F_N001_100 & $\begin{array}{l}\text { Euphorbia } \\
\text { paralias }\end{array}$ & V & $\mathrm{H}$ & 3 & Cover \\
\hline EU_F_N001_1bb & 1 & EU_F_N001_100 & Galium arenarium & $\mathrm{V}$ & $\mathrm{H}$ & 0.5 & Cover \\
\hline EU_F_N001_1bb & 1 & EU_F_N001_100 & $\begin{array}{l}\text { Hieracium } \\
\text { eriophorum }\end{array}$ & V & $\mathrm{H}$ & 1 & Cover \\
\hline EU_F_N001_1bb & 1 & EU_F_N001_100 & $\begin{array}{l}\text { Leontodon } \\
\text { saxatilis subsp. } \\
\text { saxatilis }\end{array}$ & V & $\mathrm{H}$ & 1 & Cover \\
\hline
\end{tabular}


Appendix 2. Overview of the new datasets in GrassPlot v. 2.00 compared to GrassPlot v. 1.00, including datasets with increased plot numbers (CH_B, with 2,700 additional plots, ES_P, with 3,104 additional plots; UA_F, 115; IR_A, 102; RU_I, 39). See below for quoted references. $N_{\text {all }}=$ total number of plots; $N_{\text {ind }}=$ independent plots; $N_{\text {nes }}=$ nested-plot series with at least four grain sizes.

\begin{tabular}{|c|c|c|c|c|c|c|c|c|}
\hline $\begin{array}{l}\text { Dataset } \\
\text { ID }\end{array}$ & Short dataset name & Country/ies & Province: location & Data owner(s) & Reference(s) & $N_{\text {all }}$ & $N_{\text {ind }}$ & $N_{\text {nes }}$ \\
\hline \multicolumn{9}{|c|}{ EDGG Expeditions/Field Workshops: } \\
\hline AT_E & EDGG Eastern Alps & Austria & $\begin{array}{l}\text { Tyrol, Styria and } \\
\text { Carinthia }\end{array}$ & $\begin{array}{l}\text { Martin Magnes, Elías Afif, } \\
\text { Christian Berg, Philipp } \\
\text { Kirschner, Ermin Mašić, } \\
\text { Helmut Mayrhofer }\end{array}$ & $\begin{array}{l}\text { Magnes et al. } \\
\text { (2018) }\end{array}$ & 232 & 52 & 15 \\
\hline \multicolumn{9}{|c|}{ Individually contributed datasets: } \\
\hline AS_A & $\begin{array}{l}\text { Nowak_Kyrgyzstan \& } \\
\text { Tajikistan }\end{array}$ & $\begin{array}{l}\text { Tajikistan, } \\
\text { Kyrgyzstan }\end{array}$ & $\begin{array}{l}\text { Eastern Tajikistan } \\
\text { and whole } \\
\text { Kyrgyzstan }\end{array}$ & $\begin{array}{l}\text { Arkadiusz Nowak, Ewelina } \\
\text { Klichowska, Marcin Nobis, } \\
\text { Anna Wróbel }\end{array}$ & & 156 & 12 & 12 \\
\hline AT_D & Essl, Austria old plots & Austria & & Franz Essl & & 29 & 29 & 0 \\
\hline AT_F & Mayer_Obergurgl & Austria & $\begin{array}{l}\text { Northern Tyrol: } \\
\text { Obergurgl }\end{array}$ & $\begin{array}{l}\text { Roland Mayer, Brigitta } \\
\text { Erschbamer }\end{array}$ & $\begin{array}{l}\text { Mayer et al. (2009); } \\
\text { Mayer \& } \\
\text { Erschbamer (2017) }\end{array}$ & 216 & 108 & 0 \\
\hline$A Z \_A$ & Etzold Caucasus & Azerbaijan & $\begin{array}{l}\text { Eastern Greater } \\
\text { Caucasus: } \\
\text { Shahdag }\end{array}$ & $\begin{array}{l}\text { Jonathan Etzold, Tobias } \\
\text { Dahms, Michael Manthey, } \\
\text { Jan Peters }\end{array}$ & Etzold et al. (2016) & 1,013 & 204 & 204 \\
\hline$A Z \_B$ & Peper Gobustan & Azerbaijan & $\begin{array}{l}\text { Gobustan region: } \\
\text { Gobustan and } \\
\text { Jeiranchel }\end{array}$ & $\begin{array}{l}\text { Jan Peper, Michael } \\
\text { Manthey }\end{array}$ & $\begin{array}{l}\text { Peper et al. (2010a, } \\
\text { b) }\end{array}$ & 1,020 & 204 & 204 \\
\hline BE_A & $\begin{array}{l}\text { Van } \\
\text { Meerbeek_Flanders }\end{array}$ & Belgium & Flanders & Koenraad Van Meerbeek & $\begin{array}{l}\text { Van Meerbeek et al. } \\
(2014)\end{array}$ & 90 & 90 & 0 \\
\hline BG_B & BioBio_Bulgaria & Bulgaria & $\begin{array}{l}\text { Rhodope } \\
\text { Mountains }\end{array}$ & Idoia Biurrun & Lüscher et al. (2016) & 272 & 68 & 68 \\
\hline $\mathrm{CH}_{-} \mathrm{B}$ & Bergamini Switzerland & Switzerland & & $\begin{array}{l}\text { Ariel Bergamini, Steffen } \\
\text { Boch, Klaus Ecker }\end{array}$ & $\begin{array}{l}\text { Bergamini et al. } \\
(2013,2016) ; \text { Tillé \& } \\
\text { Ecker (2014); Boch } \\
\text { et al. (2018, 2019a, } \\
\text { b) }\end{array}$ & 4,779 & 4,779 & 0 \\
\hline $\mathrm{CH}_{-} \mathrm{C}$ & Dengler Wädenswil & Switzerland & $\begin{array}{l}\text { Canton of Zürich: } \\
\text { Campus Grüental, } \\
\text { Wädenswil }\end{array}$ & $\begin{array}{l}\text { Jürgen Dengler, Stefan } \\
\text { Widmer }\end{array}$ & $\begin{array}{l}\text { Dengler \& Widmer } \\
\text { (2018) }\end{array}$ & 227 & 18 & 18 \\
\hline CH_D & Dengler_Ausserberg & Switzerland & Valais: Ausserberg & $\begin{array}{l}\text { Jürgen Dengler, Manuel } \\
\text { Babbi, Regula Billeter, } \\
\text { Iwona Dembicz }\end{array}$ & Dengler et al. (2019) & 61 & 25 & 3 \\
\hline $\mathrm{CH}_{-} \mathrm{E}$ & Dengler Alp Glivers & Switzerland & $\begin{array}{l}\text { Grisons: Sumvtig- } \\
\text { Cumpadinals, Alp } \\
\text { Glivers }\end{array}$ & $\begin{array}{l}\text { Jürgen Dengler, Daniel } \\
\text { Hepenstrick, Stefan } \\
\text { Widmer }\end{array}$ & $\begin{array}{l}\text { Hepenstrick et al. } \\
(2018)\end{array}$ & 39 & 3 & 3 \\
\hline $\mathrm{CH}_{-} \mathrm{F}$ & BioBio_Switzerland & Switzerland & $\begin{array}{l}\text { Obwalden: } \\
\text { Sarden }\end{array}$ & Philippe Jeanneret & Lüscher et al. (2016) & 260 & 65 & 65 \\
\hline CH_G & Meier Switzerland & Switzerland & & Eliane Meier & $\begin{array}{l}\text { Meier \& Hofer } \\
(2016)\end{array}$ & 540 & 270 & 0 \\
\hline CN_D & Deng_Mu Us desert & China & $\begin{array}{l}\text { Shaanxi: Dingbian, } \\
\text { Mu Us Desert }\end{array}$ & Lei Deng & Deng et al. (2014) & 36 & 36 & 0 \\
\hline CN_E & Deng_Loess Plataeu & China & & Lei Deng & Deng et al. (2016) & 330 & 330 & 0 \\
\hline CZ_J & Doležal Sumava & $\begin{array}{l}\text { Czech } \\
\text { Republic }\end{array}$ & $\begin{array}{l}\text { Bohemian Forest } \\
\text { Mts., Sumava }\end{array}$ & Jiří Doležal & $\begin{array}{l}\text { Mašková et al. } \\
\text { (2009); Doležal et al. } \\
(2011)\end{array}$ & 225 & 15 & 15 \\
\hline $\mathrm{CZ} \_\mathrm{K}$ & Doležal_Benesov & $\begin{array}{l}\text { Czech } \\
\text { Republic }\end{array}$ & Benesov & Jiří Doležal, Jan Lepš & Lepš et al. (2007) & 60 & 60 & 0 \\
\hline DE_S & BioBio CSR Germany & Germany & $\begin{array}{l}\text { Southern Bavaria: } \\
\text { near Ausburgo }\end{array}$ & Sebastian Wolfrum & Lüscher et al. (2016) & 164 & 41 & 41 \\
\hline DE_T & Manthey Greifswald & Germany & $\begin{array}{l}\text { Western } \\
\text { Pomerania: } \\
\text { Greifswald } \\
\end{array}$ & Michael Manthey & & 913 & 83 & 83 \\
\hline ES_P & Alfaro Picos de Europa & Spain & $\begin{array}{l}\text { Asturias and } \\
\text { Cantabria: Picos } \\
\text { de Europa }\end{array}$ & $\begin{array}{l}\text { Borja Jiménez-Alfaro, } \\
\text { Alvaro Bueno, Corrado } \\
\text { Marcenò }\end{array}$ & $\begin{array}{l}\text { Jímenez-Alfaro et al. } \\
\text { (2010) }\end{array}$ & 3,120 & 16 & 16 \\
\hline
\end{tabular}




\section{Appendix 2. Continuation.}

\begin{tabular}{|c|c|c|c|c|c|c|c|c|}
\hline $\begin{array}{l}\text { Dataset } \\
\text { ID }\end{array}$ & Short dataset name & Country/ies & Province: location & Data owner(s) & Reference(s) & $N_{\text {all }}$ & $N_{\text {ind }}$ & $N_{\text {nes }}$ \\
\hline ES_Q & Löbel Tenerife & Spain & $\begin{array}{l}\text { Canary islands, } \\
\text { Tenerife: Anaga Mts. }\end{array}$ & $\begin{array}{l}\text { Swantje Löbel, Jürgen } \\
\text { Dengler }\end{array}$ & $\begin{array}{l}\text { Löbel \& Dengler } \\
\text { (2002) }\end{array}$ & 18 & 13 & 1 \\
\hline ES_R & de Bello NE Spain & Spain & $\begin{array}{l}\text { Catalonia and Aragón: } \\
\text { Ebro valley to } \\
\text { Pyrenees }\end{array}$ & Idoia Biurrun & $\begin{array}{l}\text { de Bello et al. } \\
\text { (2007) }\end{array}$ & 75 & 15 & 15 \\
\hline ES_S & Biurrun Urumea & Spain & $\begin{array}{l}\text { Basque Country: } \\
\text { Urumea stream }\end{array}$ & Idoia Biurrun & Aramburu (2017) & 34 & 34 & 0 \\
\hline ES_T & Campos Zalama & Spain & $\begin{array}{l}\text { Basque Country: } \\
\text { Zalama Mt. }\end{array}$ & $\begin{array}{l}\text { Juan Antonio Campos, } \\
\text { Idoia Biurrun }\end{array}$ & & 24 & 24 & 0 \\
\hline ES_U & $\begin{array}{l}\text { Pladevall Pyrenean } \\
\text { fens }\end{array}$ & Spain & Catalonia: Pyrenees & $\begin{array}{l}\text { Eulàlia Pladevall-Izard, } \\
\text { Aaron Pérez-Haase }\end{array}$ & & 859 & 859 & 0 \\
\hline EU_E & $\begin{array}{l}\text { Roleček Hungary- } \\
\text { Romania }\end{array}$ & Hungary, Romania & $\begin{array}{l}\text { Mátra Mts., Bükk } \\
\text { Mts., Transylvania, } \\
\text { Cluj }\end{array}$ & $\begin{array}{l}\text { Jan Roleček, Pavel } \\
\text { Dřevojan, Michal Hájek }\end{array}$ & $\begin{array}{l}\text { Roleček et al. } \\
\text { (2019) }\end{array}$ & 5 & 5 & 0 \\
\hline EU_J & Janišová Carpathians & Romania, Slovakia & $\begin{array}{l}\text { Carpathians: Borišov, } \\
\text { Vel'ká Fatra Mts; } \\
\text { Ciosa, Caliman Mts; } \\
\text { Poiana Fagului, } \\
\text { Hargita }\end{array}$ & $\begin{array}{l}\text { Monika Janišová, Martin } \\
\text { Magnes }\end{array}$ & & 204 & 17 & 17 \\
\hline EU_K & Essl Europe & $\begin{array}{l}\text { Austria, Belarus, } \\
\text { Bosnia, Croatia, } \\
\text { Germany, Ireland, } \\
\text { Italy, Serbia } \\
\end{array}$ & & Franz Essl & & 766 & 239 & 159 \\
\hline EU_L & $\begin{array}{l}\text { Perez } \\
\text { Haase_Pyrenean } \\
\text { mires }\end{array}$ & Spain, Andorra & Pyrenees & $\begin{array}{l}\text { Aaron Pérez-Haase, } \\
\text { Josep Maria Ninot }\end{array}$ & & 376 & 376 & 0 \\
\hline FR_B & $\begin{array}{l}\text { Van } \\
\text { Mechelen_Langued } \\
\text { oc }\end{array}$ & France & $\begin{array}{l}\text { Languedoc-Roussillon, } \\
\text { Provence-Alpes-Côte } \\
\text { d'Azur }\end{array}$ & Carmen Van Mechelen & $\begin{array}{l}\text { Van Mechelen et } \\
\text { al. (2014) }\end{array}$ & 253 & 253 & 0 \\
\hline HU_F & BioBio_Hungary & Hungary & Homokhátság & Idoia Biurrun & $\begin{array}{l}\text { Lüscher et al. } \\
(2016)\end{array}$ & 316 & 79 & 79 \\
\hline HU_G & $\begin{array}{l}\text { Bátori Hungarian } \\
\text { dolines }\end{array}$ & Hungary & $\begin{array}{l}\text { N Hungarian } \\
\text { mountains: Aggtelek } \\
\text { Karst and Bükk Mts. }\end{array}$ & $\begin{array}{l}\text { Zoltán Bátori, Tünde } \\
\text { Farkas, András Vojtkó }\end{array}$ & $\begin{array}{l}\text { Bátori et al. } \\
\text { (2017) }\end{array}$ & 356 & 356 & 0 \\
\hline IN_A & $\begin{array}{l}\text { Doležal Ladakh } \\
\text { unpublished }\end{array}$ & India & $\begin{array}{l}\text { Jammu \& Kashmir: } \\
\text { East Ladakh, SW } \\
\text { Tibetan Plateau }\end{array}$ & Jiří Doležal & & 369 & 369 & 0 \\
\hline IN_B & $\begin{array}{l}\text { Doležal Ladakh } \\
\text { nested }\end{array}$ & India & $\begin{array}{l}\text { Jammu \& Kashmir: } \\
\text { East Ladakh, SW } \\
\text { Tibetan Plateau }\end{array}$ & Jiří Doležal & $\begin{array}{l}\text { Dvorský et al. } \\
\text { (2011) }\end{array}$ & 384 & 192 & 0 \\
\hline IR_A & $\begin{array}{l}\text { Naqinezhad Central } \\
\text { Alborz }\end{array}$ & Iran & $\begin{array}{l}\text { Alborz Mts.: Central } \\
\text { Alborz, Damavand }\end{array}$ & $\begin{array}{l}\text { Alireza Naqinezhad, } \\
\text { Amir Talebi }\end{array}$ & Talebi (2019) & 459 & 27 & 27 \\
\hline IT_Q & EGC Sulmona & Italy & $\begin{array}{l}\text { Chieti province: } \\
\text { Palena: San Nicola }\end{array}$ & $\begin{array}{l}\text { Giampiero Ciaschetti, } \\
\text { Sabina Barruscano }\end{array}$ & $\begin{array}{l}\text { Burrascano et al. } \\
(2018)\end{array}$ & 13 & 1 & 1 \\
\hline IT_R & Filibeck_Picinisco & Italy & $\begin{array}{l}\text { Central Apennines, } \\
\text { Picinisco }\end{array}$ & $\begin{array}{l}\text { Goffredo Filibeck, Laura } \\
\text { Cancellieri }\end{array}$ & & 83 & 83 & 0 \\
\hline KZ_A & Deak Kazhkstan & Kazakhstan & $\begin{array}{l}\text { Kostanay oblast: } \\
\text { Rudny, Karamendi, } \\
\text { Alexandrovskaya }\end{array}$ & $\begin{array}{l}\text { Orsolya Valkó, Zoltán } \\
\text { Bátori, Balázs Deák, } \\
\text { András Kelemen, Csaba } \\
\text { Tölgyesi }\end{array}$ & Deák et al. (2017) & 200 & 200 & 0 \\
\hline NO_C & $\begin{array}{l}\text { Grytnes North } \\
\text { Norway }\end{array}$ & Norway & Troms: Dividalen & John-Arvid Grytnes & & 231 & 33 & 33 \\
\hline NO_D & $\begin{array}{l}\text { Grytnes South } \\
\text { Norway }\end{array}$ & Norway & $\begin{array}{l}\text { Sogn og Fjordane: } \\
\text { Lærdal }\end{array}$ & John-Arvid Grytnes & & 70 & 10 & 10 \\
\hline NO_E & $\begin{array}{l}\text { Landscape } \\
\text { Monitoring Norway }\end{array}$ & Norway & & $\begin{array}{l}\text { Wenche Dramstad, } \\
\text { Wendy Fjellstad, Jutta } \\
\text { Kapfer, Christian } \\
\text { Pedersen, Hanne Sickel, } \\
\text { Grete Stokstad }\end{array}$ & & 2,276 & 569 & 569 \\
\hline NP_A & Bhatta Nepal & Nepal & $\begin{array}{l}\text { Langtang National } \\
\text { Park }\end{array}$ & $\begin{array}{l}\text { Kuber Prasad Bhatta, } \\
\text { John-Arvid Grytnes, Ole } \\
\text { Reidar Vetaas }\end{array}$ & $\begin{array}{l}\text { Bhatta et al. } \\
(2018 a, b)\end{array}$ & 252 & 126 & 0 \\
\hline
\end{tabular}




\section{Appendix 2. Continuation.}

\begin{tabular}{|c|c|c|c|c|c|c|c|c|}
\hline $\begin{array}{l}\text { Dataset } \\
\text { ID }\end{array}$ & $\begin{array}{l}\text { Short dataset } \\
\text { name }\end{array}$ & Country/ies & Province: location & Data owner(s) & Reference(s) & $N_{\text {all }}$ & $N_{\text {ind }}$ & $N_{\text {nes }}$ \\
\hline PL_D & Pielech nested & Poland & $\begin{array}{l}\text { SW Poland: Karkonosze } \\
\text { Mts. }\end{array}$ & $\begin{array}{l}\text { Remigiusz Pielech, Marek } \\
\text { Malicki }\end{array}$ & & 130 & 10 & 10 \\
\hline PL_E & Kozub Biebrza & Poland & Podlaskie & $\begin{array}{l}\text { Łukasz Kozub, Iwona } \\
\text { Dembicz, Katarzyna } \\
\text { Skłodowska }\end{array}$ & & 195 & 15 & 15 \\
\hline PT_A & Lomba_Ecochange & Portugal & $\begin{array}{l}\text { Viana do Castelo: } \\
\text { Castro Laboreiro }\end{array}$ & Ângela Lomba, João Honrado & & 24 & 24 & 0 \\
\hline RO_D & $\begin{array}{l}\text { Csergó_Transylvani } \\
\text { a }\end{array}$ & Romania & $\begin{array}{l}\text { SE Carpathians: Somlyó } \\
\text { Valley (Csík Basin) and } \\
\text { Kolos (Csík Mountains) }\end{array}$ & $\begin{array}{l}\text { Anna Mária Csergő, László } \\
\text { Demeter }\end{array}$ & $\begin{array}{l}\text { Csergő \& Demeter } \\
\text { (2012); Csergő et } \\
\text { al. (2013); Maseyk } \\
\text { et al. (2017) }\end{array}$ & 196 & 196 & 0 \\
\hline RU_I & $\begin{array}{l}\text { Belonovskaya } \\
\text { Novgorodskaya }\end{array}$ & Russia & $\begin{array}{l}\text { Novgorodskaya oblast: } \\
\text { Valday hills }\end{array}$ & $\begin{array}{l}\text { Elena Belonovskaya, } \\
\text { Nadezda Tsarevskaya }\end{array}$ & $\begin{array}{l}\text { Belonovksaya \& } \\
\text { Tsarevskaya } \\
(2018)\end{array}$ & 49 & 7 & 4 \\
\hline RU_K & Mirin Belogorie & Russia & $\begin{array}{l}\text { Belgorod region: } \\
\text { reserve Belogorie }\end{array}$ & $\begin{array}{l}\text { Denis Mirin, Ekaterina } \\
\text { Zlotnikova }\end{array}$ & & 26 & 2 & 2 \\
\hline RU_L & Dolnik South Ural & Russia & $\begin{array}{l}\text { Orenburg and } \\
\text { Chelyabinsk regions }\end{array}$ & Christian Dolnik & & 91 & 7 & 7 \\
\hline RU_M & Doležal Kamchatka & Russia & $\begin{array}{l}\text { Kamchatka: Koryto } \\
\text { Glacier Valley }\end{array}$ & Jiří Doležal & & 80 & 10 & 10 \\
\hline SE_E & $\begin{array}{l}\text { Alatalo Subarctic } \\
\text { Sweden }\end{array}$ & Sweden & Norbotten: Latnjajaure & $\begin{array}{l}\text { Juha M. Alatalo, Annika } \\
\text { Jägerbrand, Ulf Molau }\end{array}$ & $\begin{array}{l}\text { Alatalo et al. } \\
\text { (2014 a, b; 2015a, } \\
\text { b; 2016; 2017) }\end{array}$ & 20 & 20 & 0 \\
\hline SE_F & $\begin{array}{l}\text { Waldén Sweden } \\
\text { restoration }\end{array}$ & Sweden & SE Sweden & $\begin{array}{l}\text { Emelie Waldén, Regina } \\
\text { Lindborg }\end{array}$ & $\begin{array}{l}\text { Waldén \& } \\
\text { Lindborg (2016) }\end{array}$ & 50 & 50 & 0 \\
\hline TJ_A & Nowak_Tajikistan & Tajikistan & Western Tajikistan & $\begin{array}{l}\text { Arkadiusz Nowak, Iwona } \\
\text { Dembicz, Zygmunt Kącki, } \\
\text { Grzegorz Swacha, Sebastian } \\
\text { Świerszcz }\end{array}$ & & 195 & 15 & 15 \\
\hline TR_B & Güler Buca İzmir & Turkey & İzmir & Behlül Güler & & 50 & 14 & 3 \\
\hline UA_F & $\begin{array}{l}\text { Vasheniak Dniester } \\
\text { Canyon }\end{array}$ & Ukraine & $\begin{array}{l}\text { Dniester Canyon and } \\
\text { tributaries }\end{array}$ & Iuliia Vashenyak & Vasheniak (2018) & 329 & 329 & 0 \\
\hline UA_H & $\begin{array}{l}\text { Kuzemko Byzky } \\
\text { Gard }\end{array}$ & Ukraine & $\begin{array}{l}\text { Mykolaiv: Buzky Gard } \\
\text { NNP }\end{array}$ & $\begin{array}{l}\text { Anna Kuzemko, Ganna } \\
\text { Kolomients, Dariia Shyriaieva }\end{array}$ & & 26 & 2 & 2 \\
\hline UA_I & Kuzemko Kreida & Ukraine & $\begin{array}{l}\text { Kharkiv: Oskol River } \\
\text { and Vovcha River } \\
\text { valleys }\end{array}$ & $\begin{array}{l}\text { Anna Kuzemko, Olga } \\
\text { Bezrodnova, Vladimir } \\
\text { Ronkin, Galina Savchenko }\end{array}$ & & 104 & 8 & 8 \\
\hline UA_J & $\begin{array}{l}\text { Vynokurov } \\
\text { Southern Ukraine }\end{array}$ & Ukraine & Southern Ukraine & $\begin{array}{l}\text { Denys Vynokurov, Ivan Y. } \\
\text { Moysiyenko, Dariia } \\
\text { Shyriaieva }\end{array}$ & & 242 & 110 & 11 \\
\hline UA_K & $\begin{array}{l}\text { Savchenko Kharkiv } \\
\text { \& Donetsk }\end{array}$ & Ukraine & $\begin{array}{l}\text { Kharkiv and Donetsk } \\
\text { regions }\end{array}$ & $\begin{array}{l}\text { Galina Savchenko, Vladimir } \\
\text { Ronkin }\end{array}$ & & 143 & 11 & 11 \\
\hline UA_L & $\begin{array}{l}\text { Dembicz nested } \\
\text { Ukraine }\end{array}$ & Ukraine & Kherson region & $\begin{array}{l}\text { Iwona Dembicz, Łukasz } \\
\text { Kozub, Ivan Y. Moysiyenko, } \\
\text { Viktor Shapoval }\end{array}$ & & 156 & 12 & 12 \\
\hline UK_C & $\begin{array}{l}\text { BioBio_United } \\
\text { Kingdom }\end{array}$ & $\begin{array}{l}\text { United } \\
\text { Kingdom }\end{array}$ & Wales & Idoia Biurrun & $\begin{array}{l}\text { Lüscher et al. } \\
\text { (2016) }\end{array}$ & 432 & 108 & 108 \\
\hline UK_D & $\begin{array}{l}\text { Stevens Sheffield } \\
\text { acidic }\end{array}$ & $\begin{array}{l}\text { United } \\
\text { Kingdom }\end{array}$ & England: Sheffield & Carly Stevens & $\begin{array}{l}\text { Stevens et al. } \\
(2016)\end{array}$ & 196 & 196 & 0 \\
\hline UK_E & $\begin{array}{l}\text { Stevens Sheffield } \\
\text { calcareous }\end{array}$ & $\begin{array}{l}\text { United } \\
\text { Kingdom }\end{array}$ & England: Sheffield & Carly Stevens & $\begin{array}{l}\text { Stevens et al. } \\
(2016)\end{array}$ & 242 & 242 & 0 \\
\hline
\end{tabular}




\section{References and other sources to Appendix 2}

Alatalo, J.M., Jägerbrand, A.K. \& Molau, U. 2014a. Climate change and climatic events: community-, functional- and species level responses of bryophytes and lichens to constant, stepwise and pulse experimental warming in an alpine tundra. Alpine Botany 124: 81-91.

Alatalo, J.M., Little, C.J, Jägerbrand, A.K. \& Molau, U. 2014b. Dominance hierarchies, diversity and species richness of vascular plants in an alpine meadow: contrasting short and medium term responses to simulated global change. PeerJ 2:e406.

Alatalo, J.M., Jägerbrand, A.K. \& Molau, U. 2015a. Testing reliability of short-term responses to predict longer-term responses of bryophytes and lichens to environmental change. Ecological Indicators 58: 77-85.

Alatalo, J.M., Little, C.J, Jägerbrand, A.K. \& Molau, U. 2015b. Vascular plant abundance and diversity in an alpine heath under observed and simulated global change. Scientific Reports 5: 10197.

Alatalo, J.M., Jägerbrand, A.K. \& Molau, U. 2016. Impacts of different climate change regimes and extreme climatic events on an alpine meadow community. Scientific Reports 6: 21720.

Alatalo, J.M., Jägerbrand, A.K., Juhanson, J., Michelsen, A. \& Ĺuptáčik, P. 2017. Impacts of twenty years of experimental warming on soil carbon, nitrogen, moisture and soil mites across alpine/subarctic tundra communities. Scientific Reports 7: 44489.

Aramburu, S. 2017. Muhlebergia schreberi belar exotikoaren inbasioaren ikerketa Urumea ibaian [Invasion of the alien grass Muhlebergia schreberi in the Urumea stream]. Bachelor thesis. Unpublished data. University of the Basque Country, Bilbao, ES.

Bátori, Z., Vojtkó, A., Farkas, T., Szabó, A., Havadtői, K., Vojtkó, A.E., Tölgyesi, C., Cseh, V., Erdős, L., Maák, I.E. \& Keppel, G. 2017. Large- and small-scale environmental factors drive distributions of cool-adapted plants in karstic microrefugia. Annals of Botany 119: 301-309.

Belonovskaya, E. \& Tsarevskaya, N. 2018. Unpublished data from the Annual report of the Laboratory of Biogeography "Revealing of biotic indicators of sustainability and land-use optimization and creating of the natural conservation biogeographical background». Institute of Geography, RAS, Moscow, RU.

Bergamini, A., Ginzler, C., Schmidt, B.R., Küchler, M. \& Holderegger, R. 2013. Monitoring the effectiveness of habitat conservation: Making changes visible. Hotspot 28: 18-19.

Bergamini, A., Ginzler, C., Schmidt, B.R., Küchler, M. \& Holderegger, R. 2016. Die Wirkungskontrolle Biotopschutz Schweiz (WBS) in der Routinephase. $N+L$ Inside 2: 21-24.

Bhatta, K.P., Grytnes, J.-A. \& Vetaas, O.R. 2018a. Downhill shift of alpine plant assemblages under contemporary climate and land -use changes. Ecosphere 9: e02084.

Bhatta, K.P., Grytnes, J.-A. \& Vetaas, O.R. 2018b. Scale sensitivity of the relationship between alpha and gamma diversity along an alpine elevation gradient in central Nepal. Journal of Biogeography 45: 804-814.

Boch, S., Ginzler, C., Schmidt, B.R., Bedolla, A., Ecker, K., Graf, U., Küchler, H., Küchler, M., Holderegger, R. \& Bergamini, A. 2018. Wirkt der Schutz von Biotopen? Ein Programm zum Monitoring der Biotope von nationaler Bedeutung in der Schweiz. ANLiegen Natur 40: 39-48.

Boch, S., Bedolla, A., Ecker, K.T., Ginzler, C., Graf, U., Küchler, H., Küchler, M., Nobis, M.P., Holderegger, R. \& Bergamini, A. 2019a. Threatened and specialist species suffer from increased wood cover and productivity in Swiss steppes. Flora 258: 151444.

Boch, S,, Bedolla, A., Ecker, K.T., Graf, U., Küchler, H., Küchler, M., Holderegger, R. \& Bergamini, A. 2019b. Mean indicator values suggest decreasing habitat quality in Swiss dry grasslands and are robust to relocation error. Tuexenia 39: 315-334.

Burrascano, S., Ciaschetti, G., Vrahnakis, M. \& Dengler, J. 2018. Report on the 15th Eurasian Grassland Conference in Sulmona, Italy. Palaearctic Grasslands 38: 12-24.

Csergő, A.M. \& Demeter, L. 2012. Plant species diversity and traditional management in Eastern Carpathian grasslands. European Forum on Nature Conservation and Pastoralism, Derventside, UK.

Csergő, A.M., Demeter, L. \& Turkington, R. 2013. Declining diversity in abandoned grasslands of the Carpathian Mountains: do dominant species matter? PLOS One 8(8): e73533.

de Bello, F., Leps, J. \& Sebastià, M.-T. 2007. Grazing effects on the species-area relationship: Vegetation along a climatic gradient in NE Spain. Journal of Vegetation Science 18: 25-34.

Deák, B., Tölgyesi, Cs., Kelemen, A., Bátori, Z., Gallé, R., Bragina, T.M., Abil, Y.A. \& Valkó, O. 2017. Vegetation of steppic cultural heritage sites in Kazakhstan - Effects of micro-habitats and grazing intensity. Plant Ecology and Diversity 10: 509-520.

Deng, L., Sweeney, S. \& Shangguan, Z.-P. 2014. Grassland responses to grazing disturbance: plant diversity changes with grazing intensity in a desert steppe. Grass and Forage Science 69: 524533.

Deng, L., Wang, K., Li, J., Zhao, G. \& Shangguan, Z. 2016. Effect of soil moisture and atmospheric humidity on both plant productiviy and diversity of native grasslands across the Loess Plateau, China. Ecological Engineering 94: 525-531.

Dengler, J. \& Widmer, S. 2018. EDGG biodiversity plots sampled in lawns and meadows of the Campus Grüental in Wädenswil of the Zurich University of Applied Sciences (ZHAW), Switzerland. Unpublished data from the BSc. module "Vegetation analysis".

Dengler, J., Widmer, S., Staubli, E., Babbi, M., Gehler, J., Hepenstrick, D., Bergamini, A., Billeter, R., Boch, R., Rohrer, S. \& Dembicz, I. 2019. Dry grasslands of the central valleys of the Alps from a European perspective: the example Ausserberg (Valais, Switzerland). Hacquetia 18: 155-177.

Doležal, J., Maskova, Z., Leps, J., Steinbachová, D., de Bello, F., Klimešová, K., Tackenberg, O., Zemek, F. \& Kvet, J. 2011. Positive long-term effect of mulching on species and functional trait diversity in a nutrient-poor mountain meadow in Central Europe. Agriculture, Ecosystems \& Environment 145: 10-28.

Dvorský, M., Doležal, J., de Bello, F., Klimešova, J. \& Klimeš, L. 2011. Vegetation types of East Ladakh: species and growth form composition along main environmental gradients. Applied Vegetation Science 14: 132-147.

Etzold, J., Münzner, F. \& Manthley, M. 2016. Subalpine and alpine grassland communities in the northeastern Greater Caucasus of Azerbaijan. Applied Vegetation Science 19: 316-335.

Hepenstrick, D., Widmer, S. \& Dengler, J. 2018. Three EDGG Biodiversity Plots sampled in subalpine communities during a Bachelor field course at Alp Glivers (Grisons, Switzerland). Unpublished data.

Jiménez-Alfaro, B., Obeso, J.R., Abajo Chic, A., Alonso Felpete, J.I., Bueno, A., Fernández-Rodríguez, A., Marcenó, C. \& Recondo, C. 2010. Unpublished data from the project "Bases para el seguimiento de los cambios en la flora y vegetación como consecuencia del cambio climático en el Parque Nacional de los Picos de Europa". Jardín Botánico Atlántico and Oviedo University, Gijón. ES. 
Lepš, J., Doležal, J., Bezemer, T.M., Brown, V.K., Hedlund, K., Igual Arroyo, M., Jörgensen, H.B., Lawson, C.S., Mortimer, S.R., (...) \& van der Putten, W.H. 2007. Long-term effectiveness of sowing high and low diversity seed mixtures to enhance plant community development on ex-arable fields. Applied Vegetation Science 10: 97-100.

Löbel, S. \& Dengler, J. 2002. Phytodiversität und Soziologie von Federbuschgesellschaften im Anaga-Gebirge. In: Löbel, S., Conradt, F., Meier, B. \& Boch, S. (eds.) Bericht zur TeneriffaExkursion vom 9. bis 23. Februar 2002 - Tagesprotokolle und Projektberichte, pp. 74-82. Institut für Ökologie und Umweltchemie, Lüneburg, DE.

Lüscher, G., Ammari, Y., Andriets, A., Angelova, S., Arndorfer, M., Bailey, D., Balázs, K., Bogers, M., Bunce, R.G.H., (...) \& Zanetti, T. 2016. Farmland biodiversity and agricultural management on 237 farms in 13 European and two African regions. Ecology 97: 1625.

Magnes, M., Mayrhofer, H., Kirschner, P., Stöhr, O., Schwager, J., Dengler, J. \& Biurrun, I. 2018. Invitation and guide to the 11th EDGG Field Workshop: Grasslands of inneralpine dry valleys: part 1, Eastern Alps. Austria, 6-13 July 2018. Bulletin of the Eurasian Dry Grassland Group 36: 12-24.

Maseyk, F.J.F., Demeter, L., Csergő, A.M. \& Buckley, Y.M. 2017. Effect of management on natural capital stocks underlying ecosystem service provision: a 'provider group' approach. Biodiversity and Conservation 26: 3289-3305.

Mašková, Z., Dolezal, J., Květ, J. \& Zemek, F. 2009. Long-term functioning of a species-rich mountain meadow under different management regimes. Agriculture, Ecosystems \& Environment 132: 192-202.

Mayer, R. \& Erschbamer, B. 2017. Long-term effects of grazing on subalpine and alpine grasslands in the central Alps, Austria. Basic and Applied Ecology 24: 9-18.

Mayer, R., Kaufmann, R., Vorhauser, K. \& Erschbamer, B. 2009. Effects of grazing exclusion on species composition in high altitude grasslands. Basic and Applied Ecology 10: 447-455.

Meier, E.S. \& Hofer, G. 2016. Effects of plot size and their spatial arrangement on estimates of alpha, beta and gamma diversity of plants in alpine grassland. Alpine Botany 126: 167-176.
Peper, J., Jabbarov, A.Sh. \& Manthey, M. 2010a. Short-time effects of grazing abandonment on semi arid rangelands in Azerbaijan. Annals of Agrarian Science 8: 14-19.

Peper, J., Pietzsch, D. \& Manthey, M. 2010b. Semi-arid rangeland vegetation of the Greater Caucasus foothills in Azerbaijan and its driving environmental conditions. Phytocoenologia 40: 7390.

Roleček, J., Dřevojan, P., Hájková, P. \& Hájek, M. 2019. Report of new maxima of fine-scale vascular plant species richness recorded in East-Central European semi-dry grasslands. Tuexenia 39: 423-431.

Stevens, C.J., Ceulemans, T., Hodgson, J.G., Jarvis, S., Grime, J.P. \& Smart, S.M. 2016. Drivers of vegetation change in grasslands of the Sheffield region, northern England, between 1965 and 2012/13. Applied Vegetation Science 19: 187-195.

Talebi, A. 2019. Unpublished data from the PhD thesis "Ecology and biodiversity of southern slope of Damavand mountain (Scale-Dependency of ecological drivers and biodiversity patterns)". University of Tehran, Tehran, IR.

Tillé, Y. \& Ecker, K. 2014. Complex national sampling design for long-term monitoring of protected dry grasslands in Switzerland. Environmental and Ecological Statistics 21: 453-476.

Van Mechelen, C., Dutoit, T. \& Hermy, M. 2014. Mediterranean open habitat vegetation offers great potential for extensive green roof design. Landscape and Urban Planning 121: 81-91.

Van Meerbeek, K., Helsen, K. \& Hermy, M. 2014. Impact of landuse intensity on the conservation of functional and phylogenetic diversity in temperate semi-natural plant communities. Biodiversity and Conservation 23: 2259-2272.

Vasheniak, lu. 2018. Unpublished data from the project financed by Rufford Small Grant Foundation "Rare Species and Habitats Conseravtion Occured in the Limestone Outcrops of Dniester Canyon". Khmelnytskyi Institute of Interregional Academy of Personnel Management, Khmelnytskyi, UNCG, Kyiv, UA.

Waldén, E. \& Lindborg, R. 2016. Long term positive effect of grassland restoration on plant diversity - success or not? PLOS One 11(5): e0155836. 


\title{
Photo Story
}

\section{Cultural landscapes of the Lower Engadine, Switzerland}

\author{
Photos and text by Iwona Dembicz ${ }^{1,2}$ \& Jürgen Dengler ${ }^{1,3,4}$
}

\begin{abstract}
${ }^{1}$ Vegetation Ecology, Institute of Natural Resource Sciences (IUNR), Zurich University of Applied Sciences (ZHAW), Grüentalstr. 14, 8820 Wädenswil, Switzerland; i.dembicz@gmail.com, juergen.dengler@zhaw.ch

${ }^{2}$ Department of Plant Ecology and Environmental Conservation, Faculty of Biology, University of Warsaw, ul. Żwirki i Wigury 101, 02-089 Warsaw, Poland
\end{abstract}

Engadine is the name for the part of the Inn valley located in SE Switzerland, in the canton of Grisons. The valley bottom ranges from the Maloja pass at $1,815 \mathrm{~m}$ a.s.l. down to the Austrian border at 1,035 $\mathrm{m}$ a.s.l. The Lower Engadine is the section of the Engadine between Zernez and Martina, where the Inn, compared to the flat valley bottom of the Upper Engadine, is deeply carved into the terrain. On the one hand, the Lower Engadine is characterised by high mountains, Piz Linard at 3,410 m a.s.l. being the highest. Here are remote and largely untouched alpine landscapes such as those of the Swiss National Park, founded in 1914 and thus being one of the oldest in Europe and the only one in Switzerland. On the other hand, the cultural landscapes below the alpine belt here are still quite diverse and better preserved than in most other parts of Switzerland and Europe.

There are various reasons for the maintenance of structurally rich and biodiverse landscapes just here. Steep slopes have prevented, so far, strong intensification while the high Swiss agricultural subsidies ensure that most of the former grasslands are still managed as meadows and pastures. Compared to other places in Switzerland, the nitrogen input from the atmosphere is very low. Mass tourism has damaged many other parts of the Alps considerably but the Lower Engadine is only accessible by a relatively small road and, from the Swiss side, by railway, so mass tourism did not develop here to such a great extent. Moreover, the biodiversity of the Lower Engadine is enhanced by a diverse geology and steep south-facing slopes with a slightly continental climate, which supported the development of a rich xerothermic vegetation with its associated fauna. Agriculture is nearly exclusively animal-based, i.e. using meadows and pastures to feed cattle and other livestock. The grasslands below the alpine zone are semi-natural in the majority, with the exception of small areas around rocky outcrops and on steep rocky slopes, which might be free of forest

\author{
${ }^{3}$ Plant Ecology, Bayreuth Center of Ecology and Environmental Research \\ (BayCEER), University of Bayreuth, Universitätsstr. 30, 95447 Bayreuth, \\ Germany \\ ${ }^{4}$ German Centre for Integrative Biodiversity Research (iDiv) Halle-Jena- \\ Leipzig, Deutscher Platz 5e, 04103 Leipzig, Germany
}

naturally. While the grasslands of the Lower Engadine have not remained untouched by the two main threats to European grasslands, i.e. intensification and abandonment, they are still in a comparatively good state and an attractive place for grassland ecologists to visit and survey.

\section{Further reading}

Braun-Blanquet, J. 1961. Die inneralpine Trockenvegetation. Fischer, Stuttgart, DE: 273 pp.

Zoller, H. 1995. Vegetationskarte des Schweizerischen Nationalparks - Erläuterungen. Flück-Wirth [NationalparkForschung in der Schweiz No. 85], Zernez, CH: 108 pp. + map.

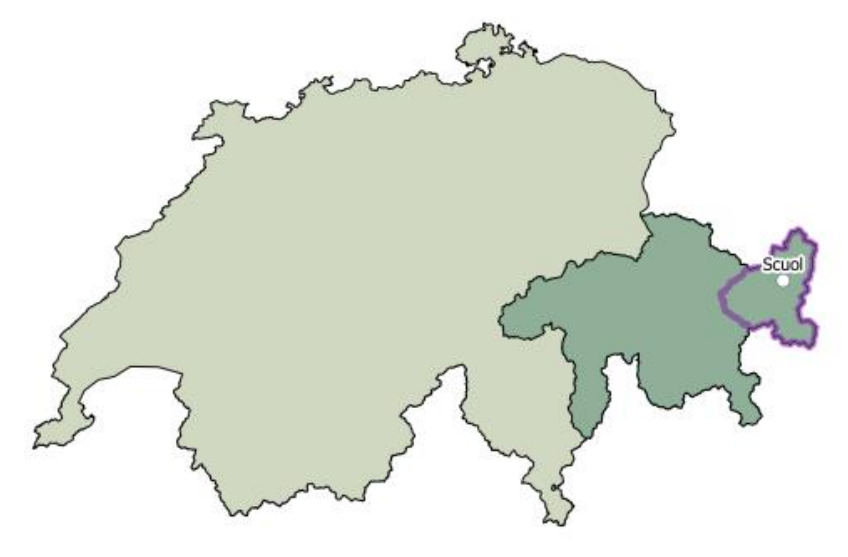

Location of the administrative district of Engiadina Bassa (Lower Engadine)/Val Müstair Region (marked with violet framing) in Switzerland, and in the canton of Grisons (darker green colour). 


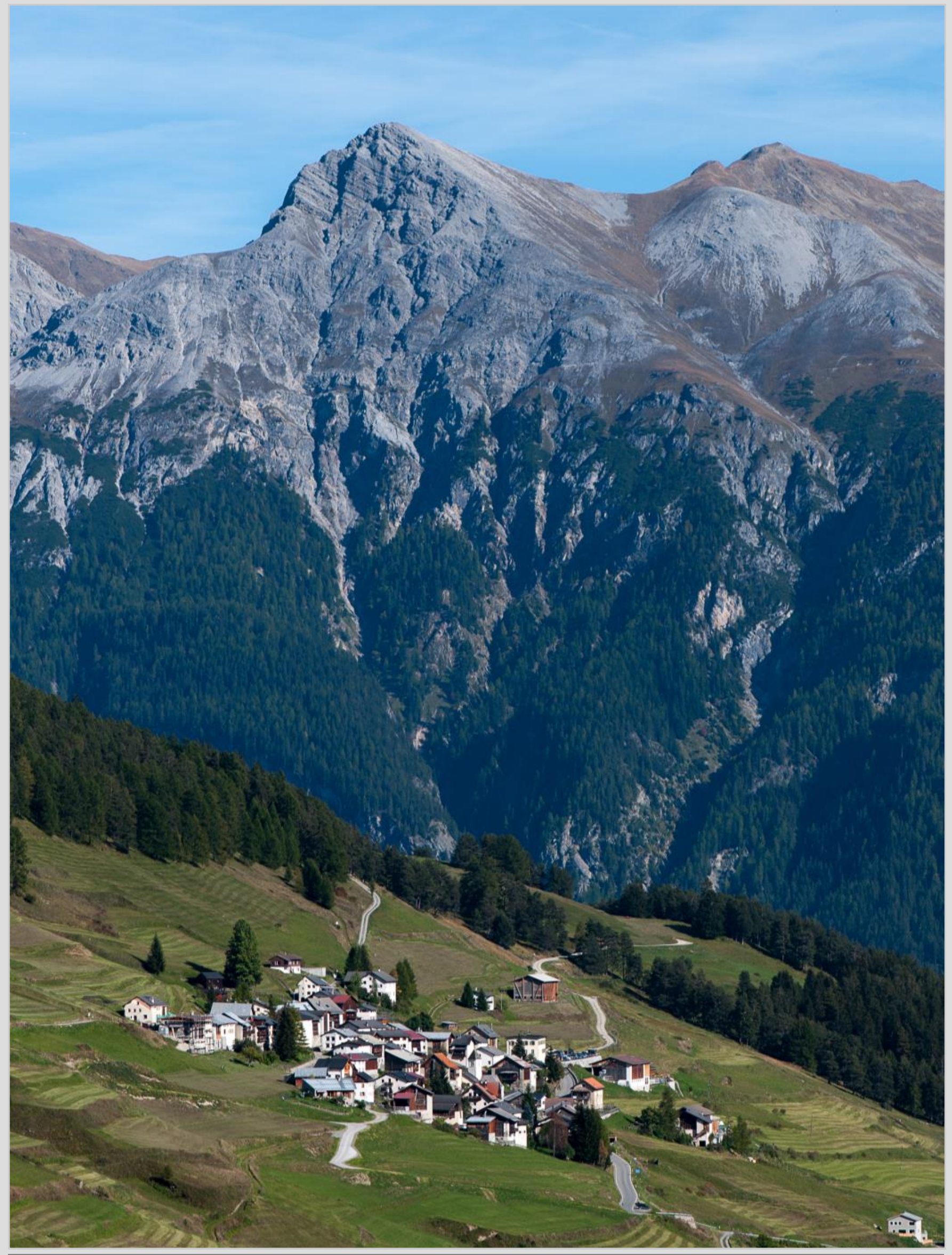

In the Lower Engadine, the villages like Vnà (pictured), are situated on the sunny terraces typically several hundred meters above the river. 


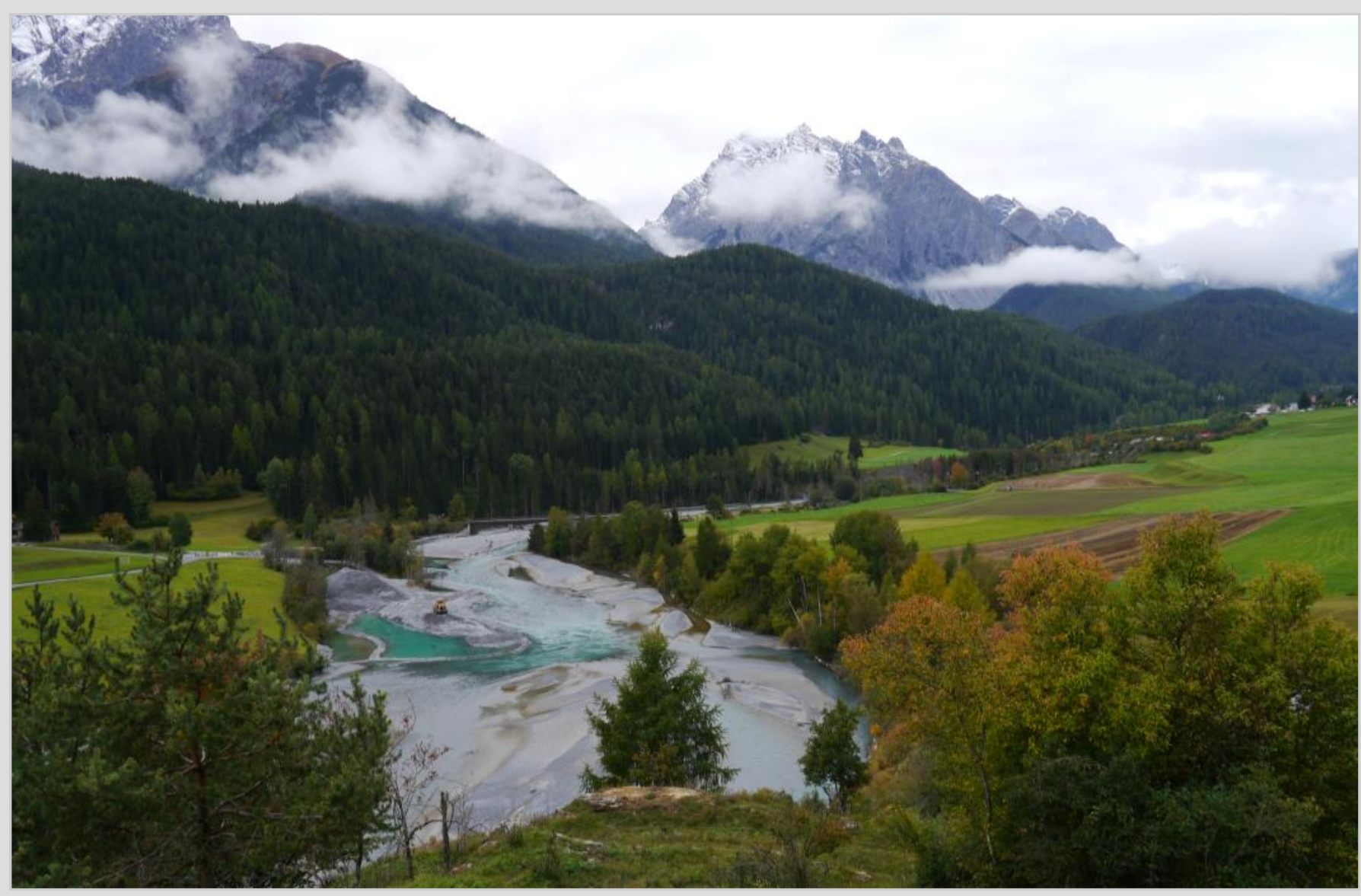

The Engadine takes its name from the river Inn (Romansh: En).
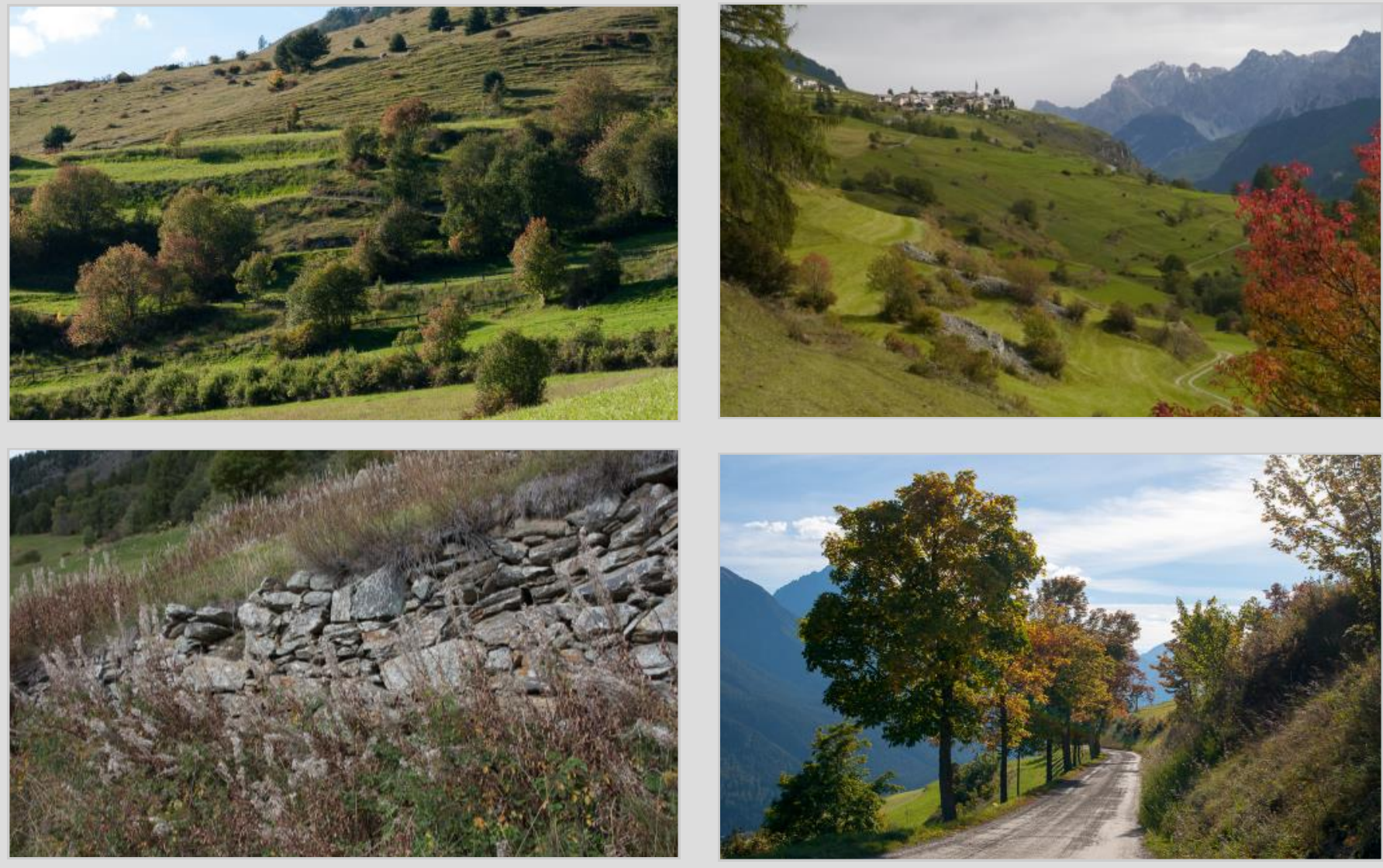

The richly structured cultural landscapes of the Lower Engadine, apart from grasslands, contains hedgerows, single trees and alleys, terraces and road verges, outcrops, stone heaps and stone walls. Thus the landscape is a diverse mosaic, full of colours throughout the seasons. 

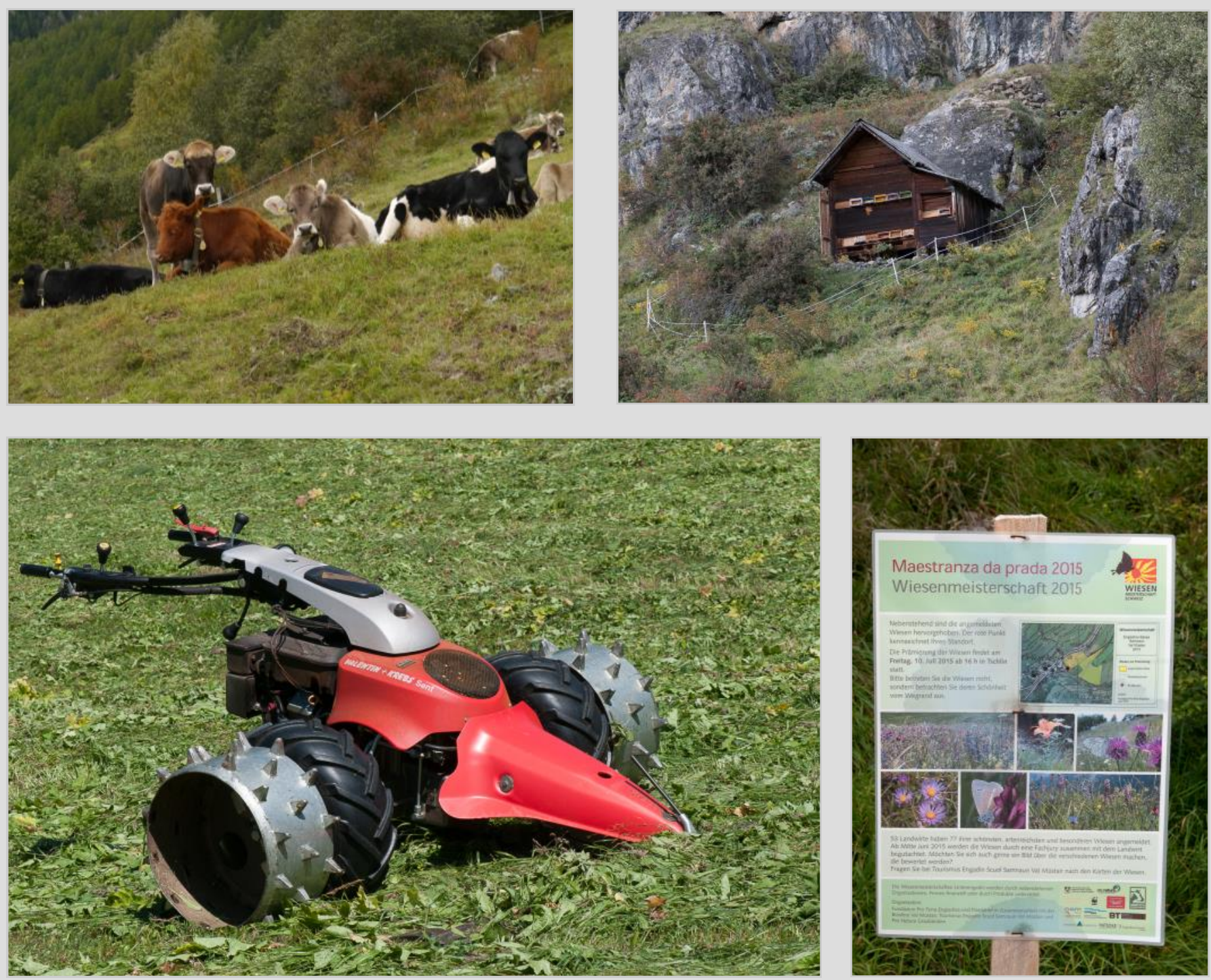

The grasslands are managed as pastures and meadows to feed mainly cattle, while other land uses such as beekeeping are also present. Maintenance of the traditional meadows on the steep slopes is challenging under present-day conditions and depends on subsidies: the scythe is meanwhile replaced by expensive high-tech machinery that allows mowing of even the steepest slopes. A championship for the best meadows rewards those farmers who maintain the most diverse meadows, while at the same time raising public awareness about the importance of species-rich grasslands.
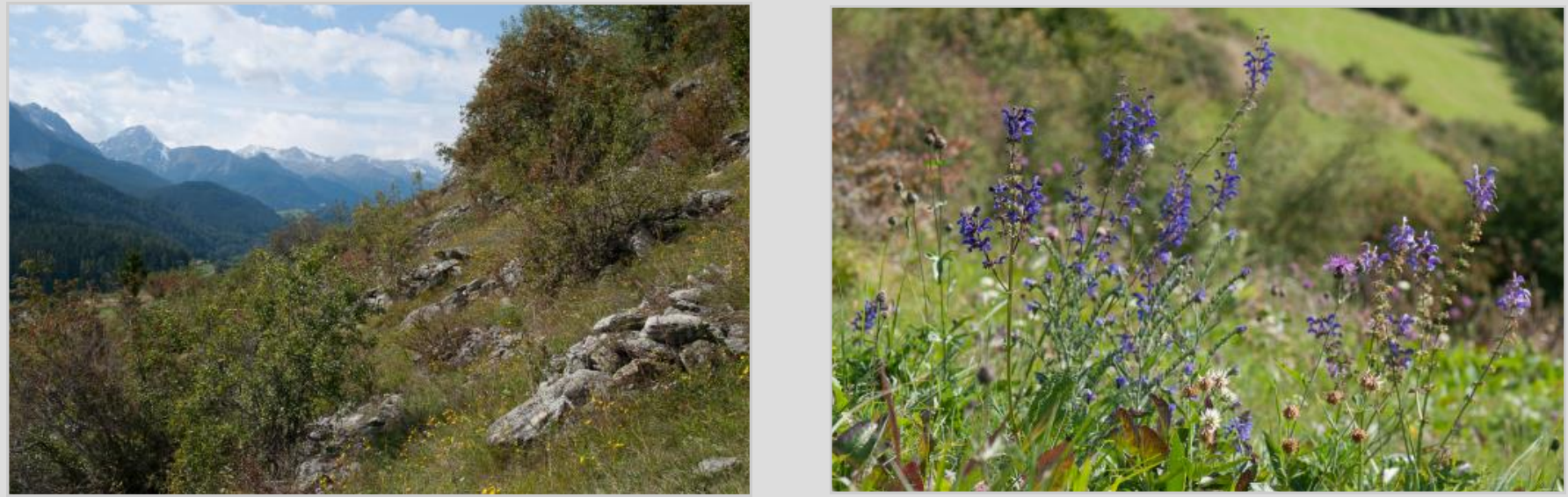

Grassland types range from rocky outcrops, through steppic grasslands, semi-dry and mesic to wet grasslands. The picture to the left shows a steppic grassland with Hieracium umbellatum, the picture to the right a semi-dry grassland with Salvia pratensis, Echium vulgare, Centaurea scabiosa and Trifolium montanum. 

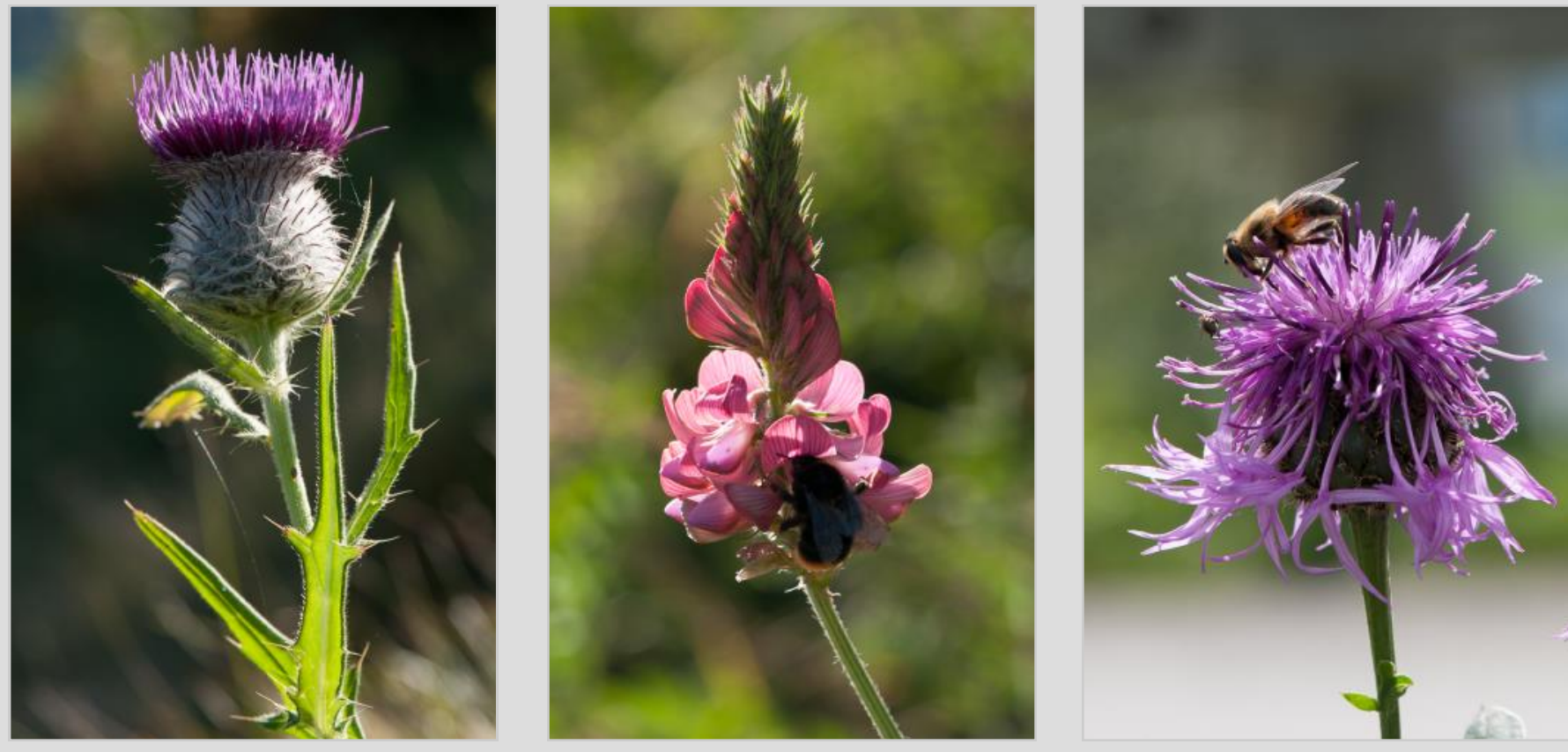

Typical vascular plants of the semi-dry grasslands: Cirsium eriophorum, Onobrychis viciifolia and Centaurea scabiosa (from left to right).
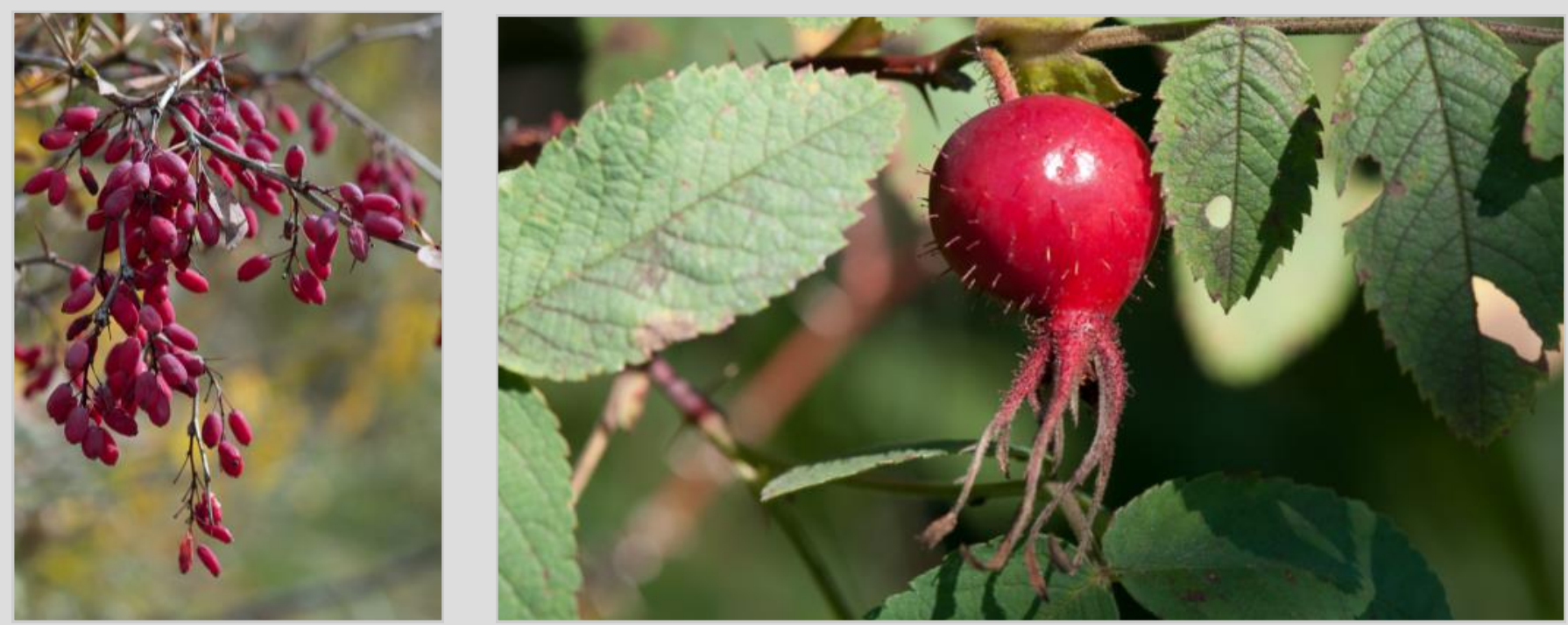

The hedgerows and shrub patches harbour colourful fruits in autumn, here Berberis vulgaris (left) and Rosa villosa (right).
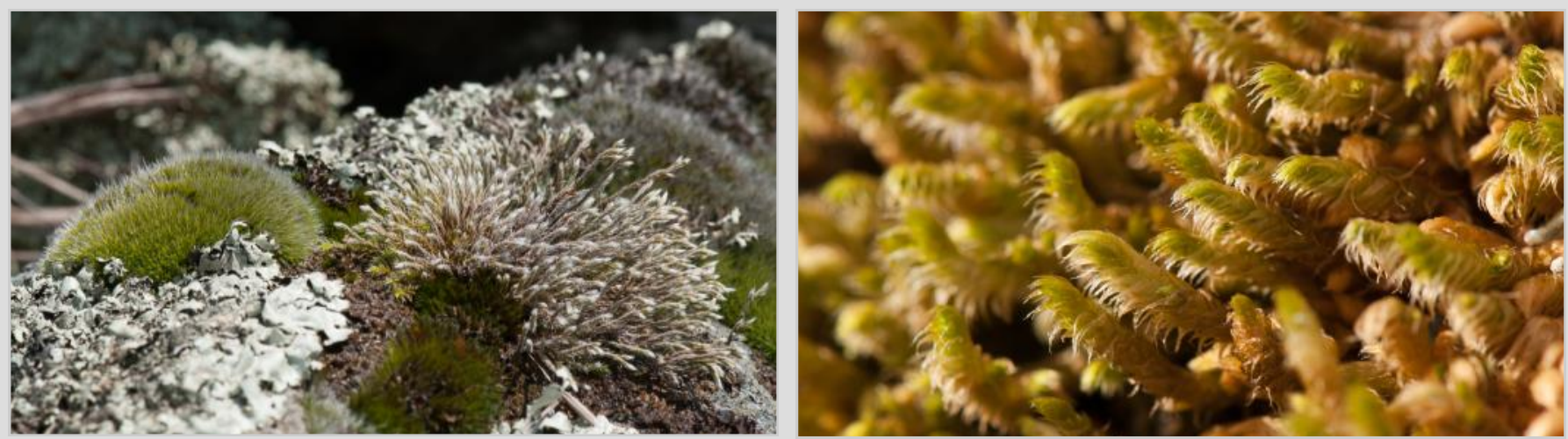

Particularly on and around rocky outcrops, the lichen and bryophyte flora can be rich: cryptogam community with Hedwigia ciliata agg. (left), Rhytidium rugosum (right). 

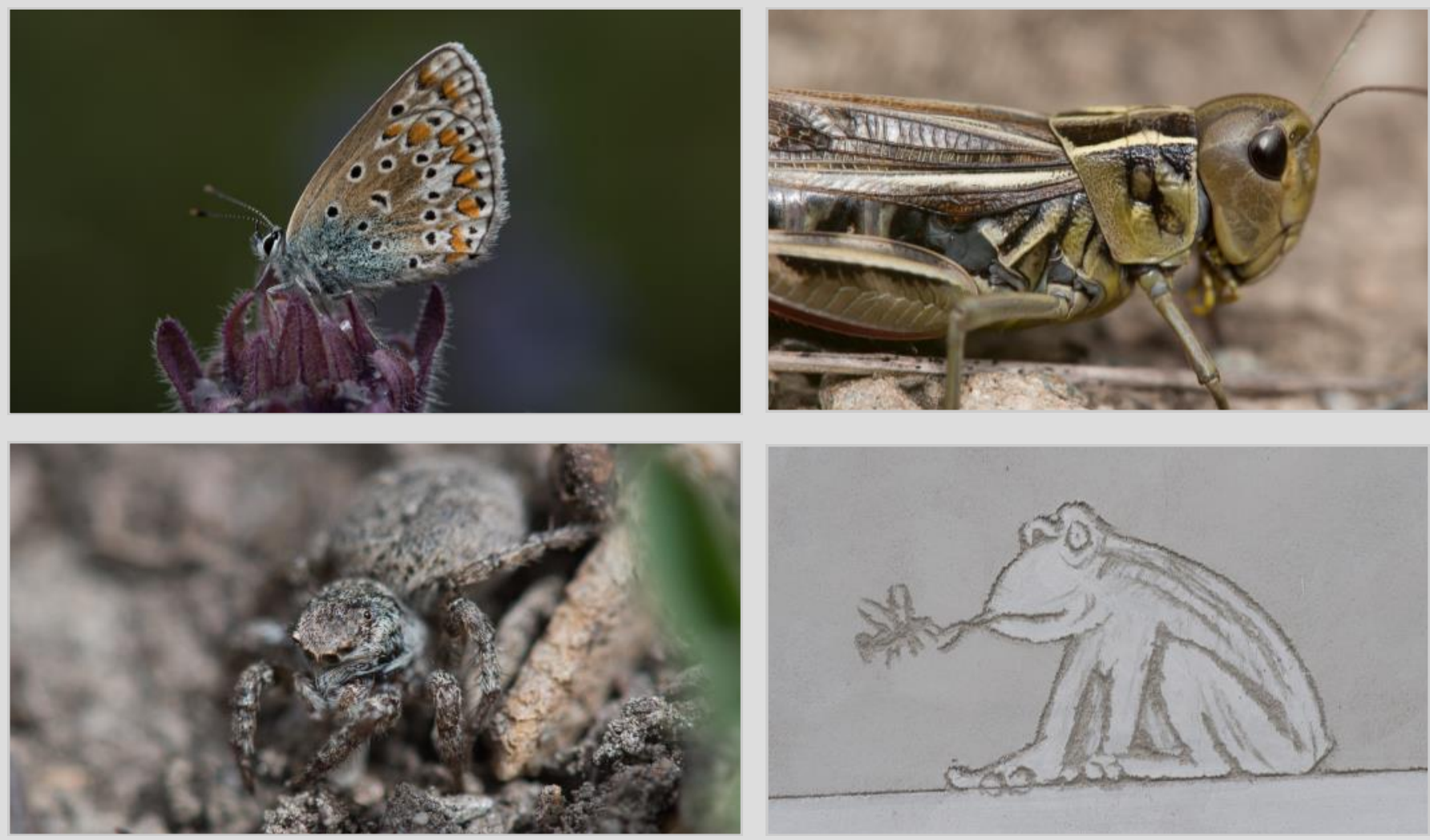

The semi-natural grasslands, particularly the dry grasslands, also harbour a rich fauna: Polyommatus icarus (upper left), Arcyptera fusca (upper right) and a jumping spider, possibly a female of Aelurillus v-insignitus (lower left); and this diversity is reflected in the typical wall decorations on the Engadine houses, called sgraffito.
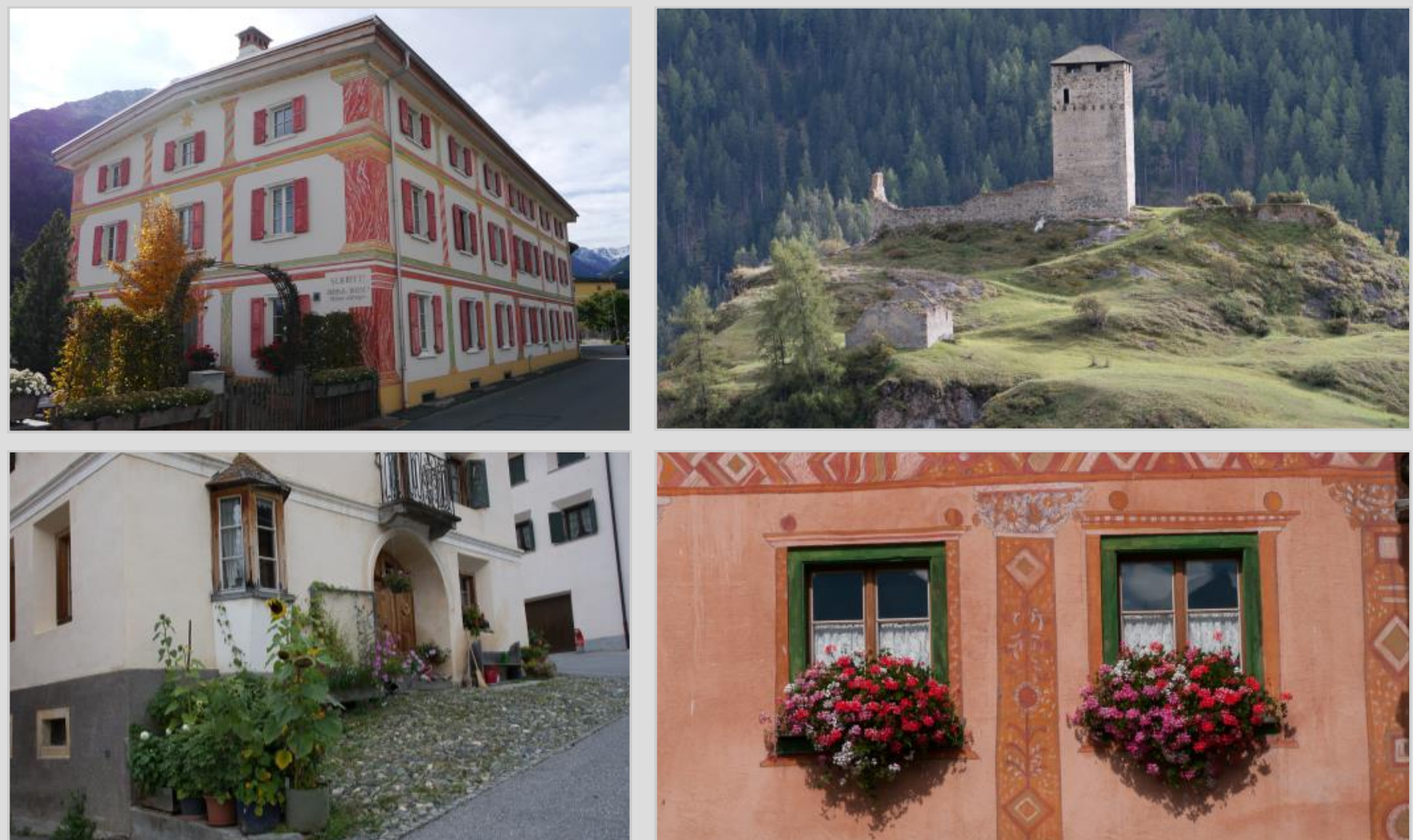

The fact that the Engadine was formerly an important traffic road over the Alps is reflected by many castles and fortified towers, which are now mostly ruins, like Ardez (upper right). Apart from sgraffiti, the Engadine houses are also decorated with paintings and flowers. 


\section{Short Contributions}

\section{Insect decline is most dramatic in grasslands in the vicinity of intensively farmed croplands}

\section{Compared to a decade ago the number of insect species within many grassland areas has decreased by approximately one third}

Various studies have reported a decline in insects over the last decades. A long-term study within protected areas in Germany attracted global interest when it reported a greater than $75 \%$ decline in insect biomass over 27 years (Hallmann et al. 2017). A review by Sánchez-Bayo \& Wyckhuys (2019) initiated a series of discussions amongst scientists on the generalization of results from single studies to a global scale. As most studies have focused either exclusively on biomass, certain species groups, or particular sites, it has been unclear if the decline can be generalized to many insect groups.

A recent study published in the journal Nature at the end of October by Seibold et al. (2019) reported a dramatic decline in several insect groups within grasslands and forests in Germany over a 10 year period (Fig. 1). The decline was most

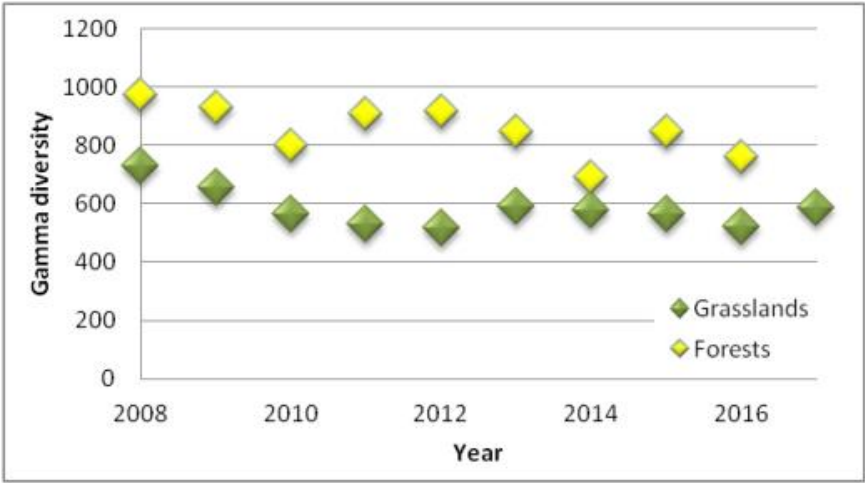

Fig. 1. Gamma diversity (total number of species per habitat per year across all plots) change in two habitats (confidence intervals not shown).

severe in grasslands neighbouring intensively-managed croplands.

A multinational team of 19 researchers conducted the study as a part of the Biodiversity Exploratories Project funded by Deutsche Forschungsgemeinschaft. The arthropod team collected more than one million insects at 290 sites in Brandenburg, Thuringia and Baden-Württemberg between 2008 and 2017. The number of individuals was determined for 22 arthropod orders and specimens from four orders (Araneae, Orthoptera, Coleoptera and Hemiptera) were identified to species level (except the latter two orders for forest specimens). The results showed that many of the nearly 2700 investigated species were in decline (Fig. 2).

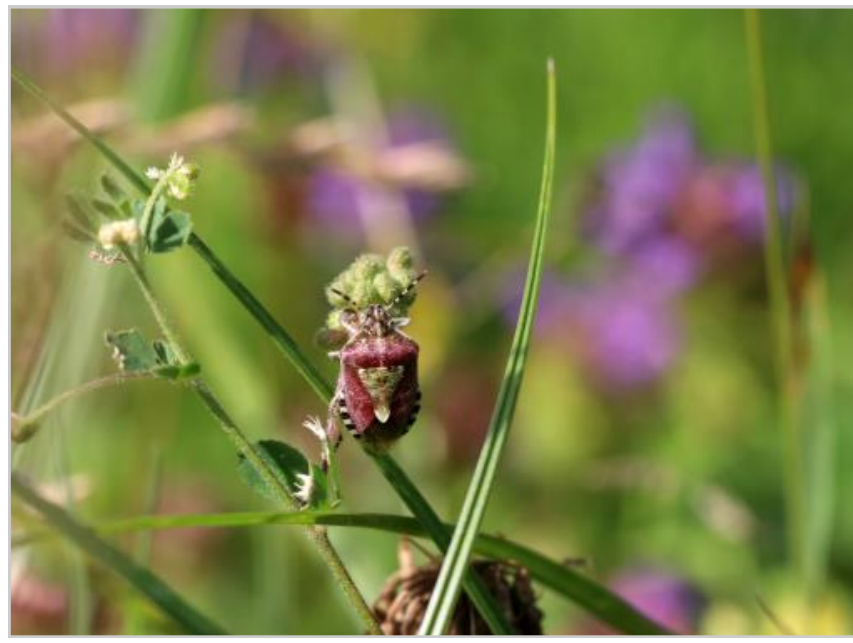

Fig. 2. Left: Populations of insect species, such as the Small Gold Grasshopper (Chrysochraon dispar), have declined (Photo: M. Fellendorf). Right: The sloe bug (Dolycoris baccarum) is one of the few species that have barely declined (Photo: S. Seibold). 

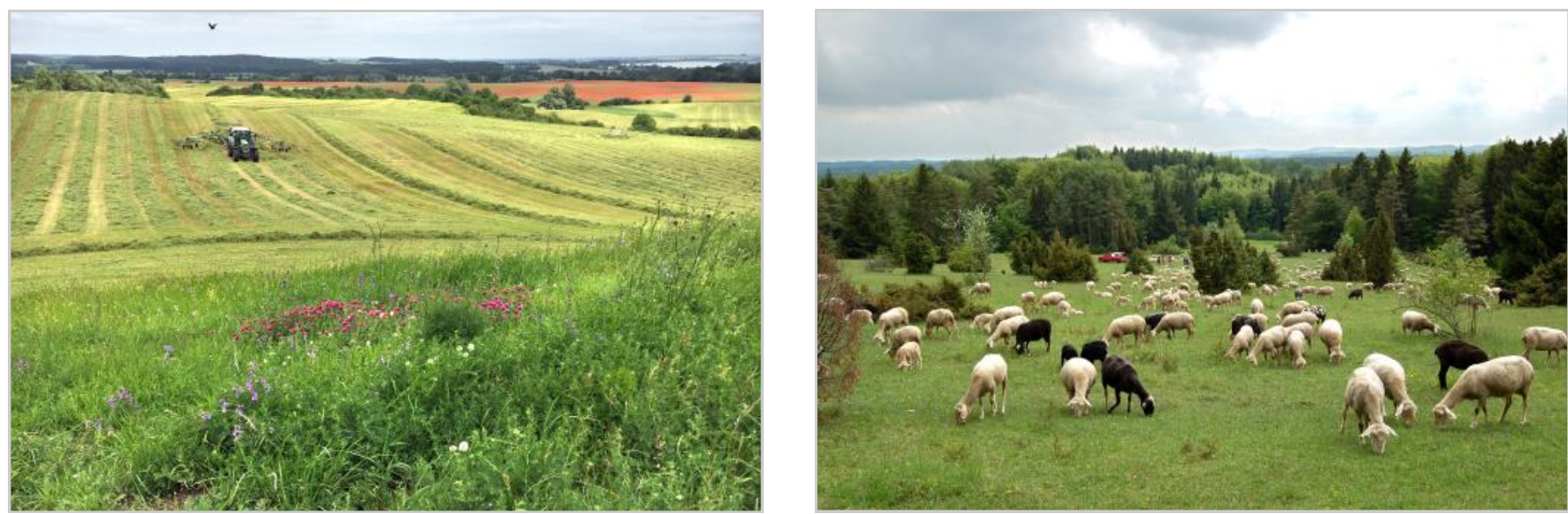

Fig. 3. Left: Meadows in the vicinity of intensively farmed areas suffer from insect species loss, such as this meadow in Schorfheide (Photo: U. Garbe). Right: Insect decline also occurs at sites managed at lower intensities, such as this sheep pasture in Schwäbische Alb only grazed few days a year (Photo: J. Hailer).

In grasslands, biomass, abundance and number of species declined by $67 \%, 78 \%$ and $34 \%$, respectively. The decline was consistent across trophic levels and mainly affected rare species; and its magnitude was independent of local land-use intensity but closely related to land-use intensity in the surrounding croplands. The biggest losses were in grasslands surrounded by intensively farmed land, where the most heavily impacted species were poor dispersers i.e. those unable to travel far (Fig. 3, left). In forests, biomass and species number, but not abundance, decreased by $41 \%$ and $36 \%$, respectively. The decline affected rare and abundant species and trends differed across trophic levels. In the forested areas the most impacted insect groups were those that cover longer distances. Further studies are needed to disentangle the relationship between the diversity of species with different dispersal abilities, their habitats, and the surrounding landscape.

Every type of forest and grassland site studied by the team was impacted, these included sheep pastures (Fig. 3, right), meadows that were mown and fertilized three to four times per year, forests dominated by planted coniferous trees, and even unmanaged forests in protected areas. Such a steep decline in insect biodiversity over 10 years is alarming but consistent with the results presented in a growing number of studies. To halt the decline a paradigm shift in landuse policy is required. Instead of implementing independent and isolated site-level conservation actions, measures to improve the habitat quality for insects needs to be implemented and coordinated across landscapes and regions and mainstreamed across all sectors involved in natural resource use in terrestrial ecosystems.

\section{References}

Hallmann, C.A., Sorg, M., Jongejans, E., Siepel, H., Hofland, N., Schwan, H., Stenmans, W., Müller, A., Sumser, H., (...) \& de Kroon, H. 2017. More than 75 percent decline over 27 years in total flying insect biomass in protected areas. PLoS One 12(10): e0185809. https://doi.org/10.1371/journal.pone.0185809.

Sánchez-Bayo, F. \& Wyckhuys, K.A.G. 2019. Worldwide decline of the entomofauna: A review of its drivers. Biological Conservation 232: 8-27. https://doi.org/10.1016/j.biocon.2019.01.020

Seibold, S., Gossner, M.M., Simons, N.K., Blüthgen, N., Müller, J., Ambarlı, D., Ammer, C., Bauhus, J., Fischer, M., (...) \& Weisser, W.W. 2019. Arthropod decline in grasslands and forests is associated with drivers at landscape level. Nature 574: 671-674. https://doi.org/10.1038/s41586-019-1684-3.

Didem Ambarlr', Freising, Germany didem.ambarli@tum.de

Sebastian Seibold, Freising, Germany seibold@tum.de

Wolfgang W. Weisser, Freising, Germany weisser@tum.de 


\section{Please, help us with your photos!}

\section{Research to understand the cultural value of permanent grasslands}

The EU Horizon 2020 SUPER-G project is running a 'Photo Competition' with a chance to win a trip to Bled, Slovenia and the Triglav National Park on 17-18 June 2020. We hope the competition will help us better understand how grasslands are valued by society.

Permanent grasslands deliver multiple public goods and services such as forage for grazing animals, resources for pollinators, carbon sequestration for mitigating greenhouse gas emissions, water regulation, and protection against erosion. Grasslands also support different types of cultural services, e.g. recreational opportunities, local identity, cultural heritage, as well as aesthetic values (Potschin \& HainesYoung 2011). However, permanent grasslands are threatened in quantity and quality for diverse reasons. Intensification, conversion to temporary grassland or arable land, afforestation, heat and drought stress are only some examples.

The SUPER-G (Developing SUstainable PERmanent Grassland systems and policies) project, which is funded by the EU H2020 program, aims to assess and co-develop sustainable grassland systems and policies in cooperation with farmers and policy makers. Thus, a major aim of the project is to establish fruitful cooperation between scientists and stakeholders.

In this project, we want to study the cultural services provided by permanent grasslands, such as those connected to biodiversity, aesthetic value, cultural heritage and recreational use. We are also interested in people's perception of the economic activities that are carried out on grasslands, as well as the perception of the threats to which permanent grasslands are exposed. A relatively new and very promising method for gathering information is photo series analysis, a non-participatory and spatial explicit method involving contributors without their active participation (e.g. Casalegno et al. 2013; Richards \& Friess 2015). As this method requires many photos well distributed across Europe, we launched the "SUPER-G Photo Competition" on European permanent grasslands.
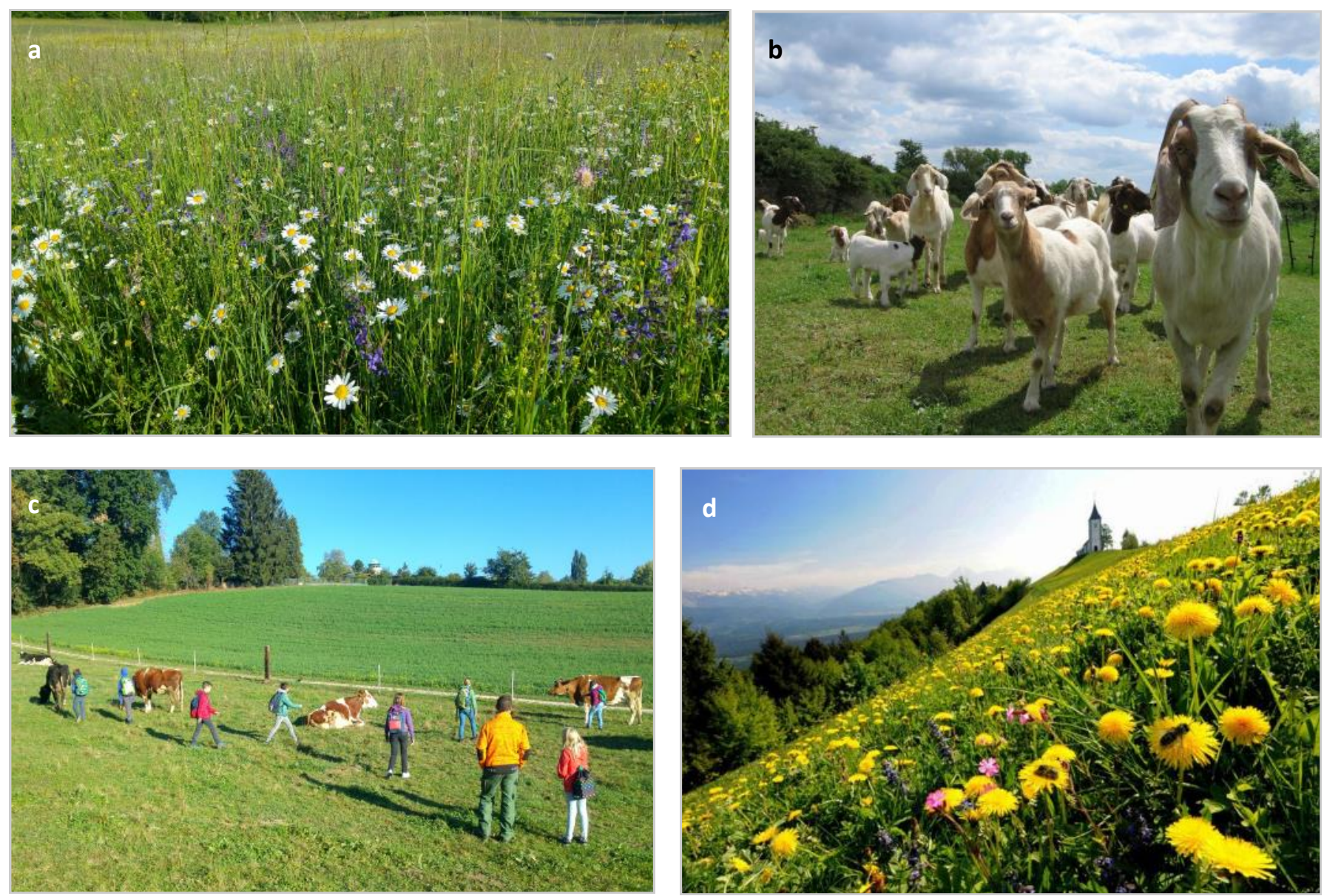

Photos as examples of the photo competition topics: a) Flower-rich meadow in Switzerland; b) Goats on dry grassland in Germany; c) School kids and cows in Switzerland. Photos: V.H. Klaus. d) Flowering meadows from Slovenia. Photo: F. Šivic. 
We are looking for photos connected to permanent grasslands such as meadows, pastures or any other grassland types that contain information on the following topics:

1. Wildlife and biodiversity,

2. Cultural values of the grasslands,

3. Farmlands, outdoor farming activities,

4. Outdoor recreation in grasslands,

5. Risks and threats on grasslands.

The authors of the three winning photographs will be invited to a place where wonderful grasslands can be found: the city of Bled, in Slovenia in June 2020, and the wonderful Triglav National Park!

To participate in our photo competition, please, go to www.super-g.eu/2019-photo-competition

For more information write to Eszter Lellei-Kovács: lke.photos.super-g@okologia.mta.hu

Project website: www.super-g.eu

Deadline: 31 January 2020

Evaluation will be conducted by a board of the SUPER-G project.

\section{Corrigendum to} Pachlatko J., Wyttenbach M., \& Dengler J. “Alpine grassland vegetation at Gornergrat (Canton of Valais, Switzerland): Vegetation mapping for environmental planning"

In the article of Pachlatko et al. (2019, Palaearctic Grasslands, 43, 23-37), unfortunately an error has been published. In the caption of Fig. 15 on page 36, it should read Aster alpinus instead of Erigeron alpinus.

Male Alpine ibex (Capra ibex) resting in an alpine grassland, Grisons, Switzerland. Photo: J. Dengler.
We look forward to receiving your photos!

\section{References}

Casalegno, S., Inger, R., DeSilvey, C. \& Gaston, K.J. 2013. Spatial Covariance between Aesthetic Value \& Other Ecosystem Services. PLOS One 8: e68437.

Potschin, M.B. \& Haines-Young, R.H. 2011. Ecosystem services: Exploring a geographical perspective. Progress in Physical Geography 35: 575-594.

Richards, D.R. \& Friess, D.A. 2015. A rapid indicator of cultural ecosystem service usage at a fine spatial scale: Content analysis of social media photographs. Ecological Indicators 53: 187195.

Eszter Lellei-Kovács, Vácrátót, Hungary

lke.photos.super-g@okologia.mta.hu

Marija Klopčič, UL, Slovenia

Marija.Klopcic@bf.uni-lj.si

Paul Newell Price, ADAS, UK

paul.newell-price@adas.co.uk

Valentin H. Klaus, Zürich, Switzerland valentin.klaus@usys.ethz.ch

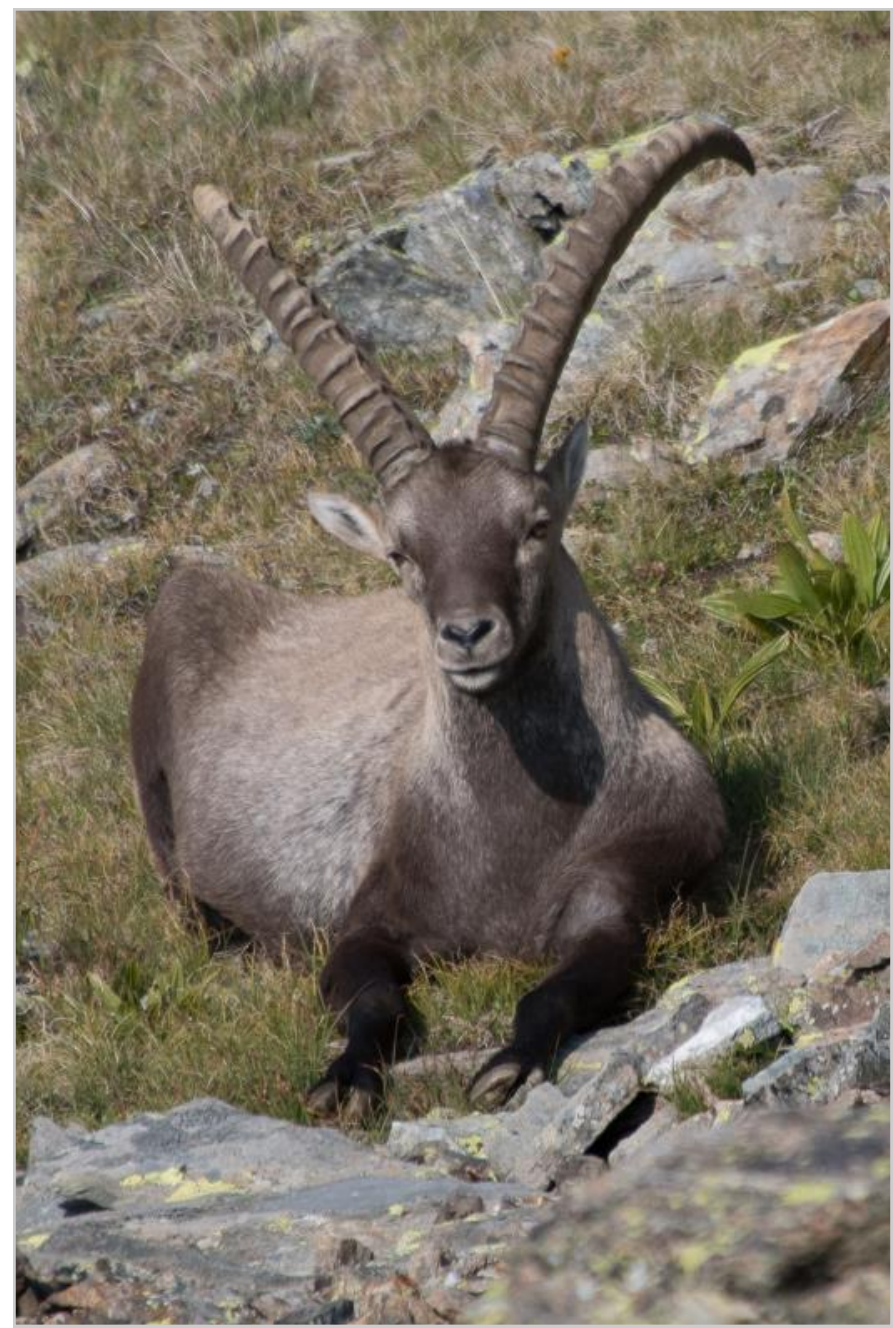




\section{Book Review}

\section{Klimešová, J. 2018. Temperate herbs: an architectural analysis. Praha: Academia, 274 pp., ISBN: 978-80-200- 2760-3 (Hardcover: 520 CZK, $20 €$ ).}

Functional analysis of plant communities based on plant morphology is deeply rooted in the history of botany and plant ecology. The pioneering work of plant ecology by Warming (Plantesamefund, 1895, translated and reworked in German as Lehrbuch der Ökologischen Pflanzengeographie co-authored by P. Gräbner, 1896) listed several growth forms of plants, which formed a basis for the life-form classification of Raunkiaer (1934). The Raunkiaer life-forms are widely cited and still used today. Most approaches to study the functioning of plant communities frequently just consider aboveground traits and interactions, however the understanding of belowground processes in plant interactions and coexistence is gaining increasing attention (Vos \& Kazan 2016; Li et al. 2017).

In the age of trait-based ecology, much analytical information related to plant architecture e.g., plant growth forms, morphology and traits of plant organs is used in research, but a unified classification of angiosperms based on plant architecture are still lacking. The comprehensive book of Klimešová (2018) is one of the first attempts to fill this gap; the author aimed to (i) provide a brief synthesis of architectural classification universal for all growth forms, (ii) to summarise architectural categories relevant for herbs in the temperate region and to (iii) introduce these categories by using examples from Central Europe. The book has a very compact 17-page intro followed by a part containing 1614 line drawings of 706 herb species in more than 200 pages. The drawings of the book were based on a more than twenty years of field research by the author and co-workers and formed the basis of the CLO-PLA database (https:// clopla.butbn.cas.cz/). As the CLO-PLA database is used frequently in trait-based analyses, this book helps to visualise the clonal and bud-bank trait categories used in the database. The book covers the most important taxa and most all genera of Central Europe and it is easy to use. The drawings are of high quality and the book is designed in an attractive, minimalist style. All in all, the book provides a very useful and comprehensive basis for researchers who would like to get familiar with the architecture of plants and belowground-trait ecology.

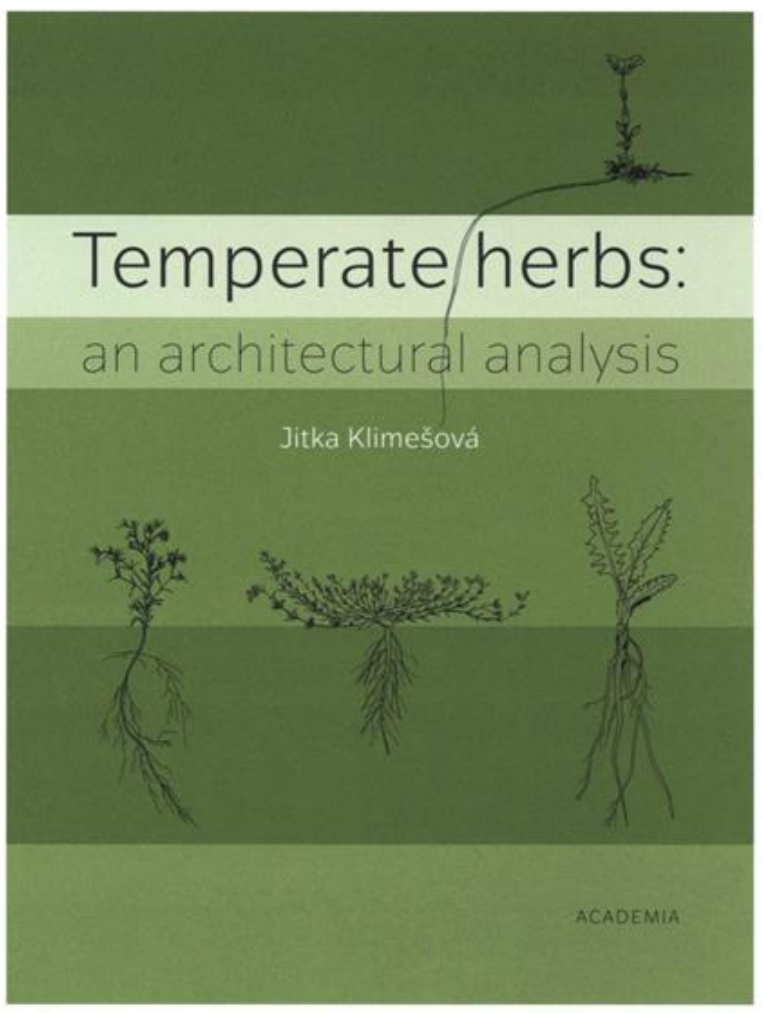

Raunkiaer, C. 1934. The life forms of plants and statistical plant geography. Oxford University Press, London.

Vos, C.M.F. \& Kazan, K. (eds.) 2016. Belowground defence strategies in plants. Springer International Publishing, $\mathrm{CH}$.

Li, H., Liu, B., Ma, Z. \& Guo, D. 2017. Diverse belowground resource strategies underlie plant species coexistence and spatial distribution in three grasslands along a precipitation gradient. New Phytologist 216: 1140-1150.

Péter Török, Debrecen, Hungary, molinia@gmail.com 


\section{Forthcoming Events}

$14^{\text {th }}$ annual meeting of the specialist group Macroecology of the Ecological Society of Germany, Austria, and Switzerland: "Macroecology of the Anthropocene"

2 - 5 March 2020, Konstanz, Germany

Conference website: https://www.biologie.uni-konstanz.de/ kleunen/macro-2020/

The International Biogeography Society Early Career Conference

17-19 April 2020 in Amsterdam, the Netherlands

Conference website: https://www.biogeography.org/event/ early-career-conference-amsterdam/

\section{$29^{\text {th }}$ European Vegetation Survey Meeting}

4-7 May 2020, Rome, Italy

Conference website: http://evs2020roma.info

\section{$9^{\text {th }}$ PLANTA EUROPA Conference}

11-15 May 2020, Paris, France

Conference website: https://www.plantaeuropa.com/planta -europa-conference-2020

$14^{\text {th }}$ EDGG Field Workshop: Ukrainian steppes along climatic gradients

25 May - 3rd June 2020, Ukraine

See details in this issue, on pp. 6-15

$10^{\text {th }}$ International Conference on Serpentine Ecology (ICSE 10)

21-30 June 2020, Ekaterinburg, Russia

Conference website: http://icse10.urfu.ru

$28^{\text {th }}$ General Meeting of the European Grassland Federation

22-25 June 2020 in Helsinki, Finland

Conference website: www.egf2020.fi

$2^{\text {nd }}$ Quarries alive International Conference

24-26 June 2020, Liege, Belgium

Conference website: http://www.gembloux.ulg.ac.be/ qa2020/

$63^{\text {rd }}$ IAVS Symposium: Vegetation in the Anthropocene 20-24 July 2020, Vladivostok, Russia

Symposium website: http://geobotanica.ru/ symposium 2020/

\section{$12^{\text {th }}$ European Conference on Ecological Restoration SER} 2020

31 August - 4 September 2020, Alicante, Spain

Conference website: https://chapter.ser.org/europe/event/ alicante-spain-ser-europe-conference/

$17^{\text {th }}$ Eurasian Grassland Conference: Grassland dynamics and conservation in a changing world

7-13 September 2020, Tolosa, Spain

See details in Palaearctic Grasslands 43: 8-13.

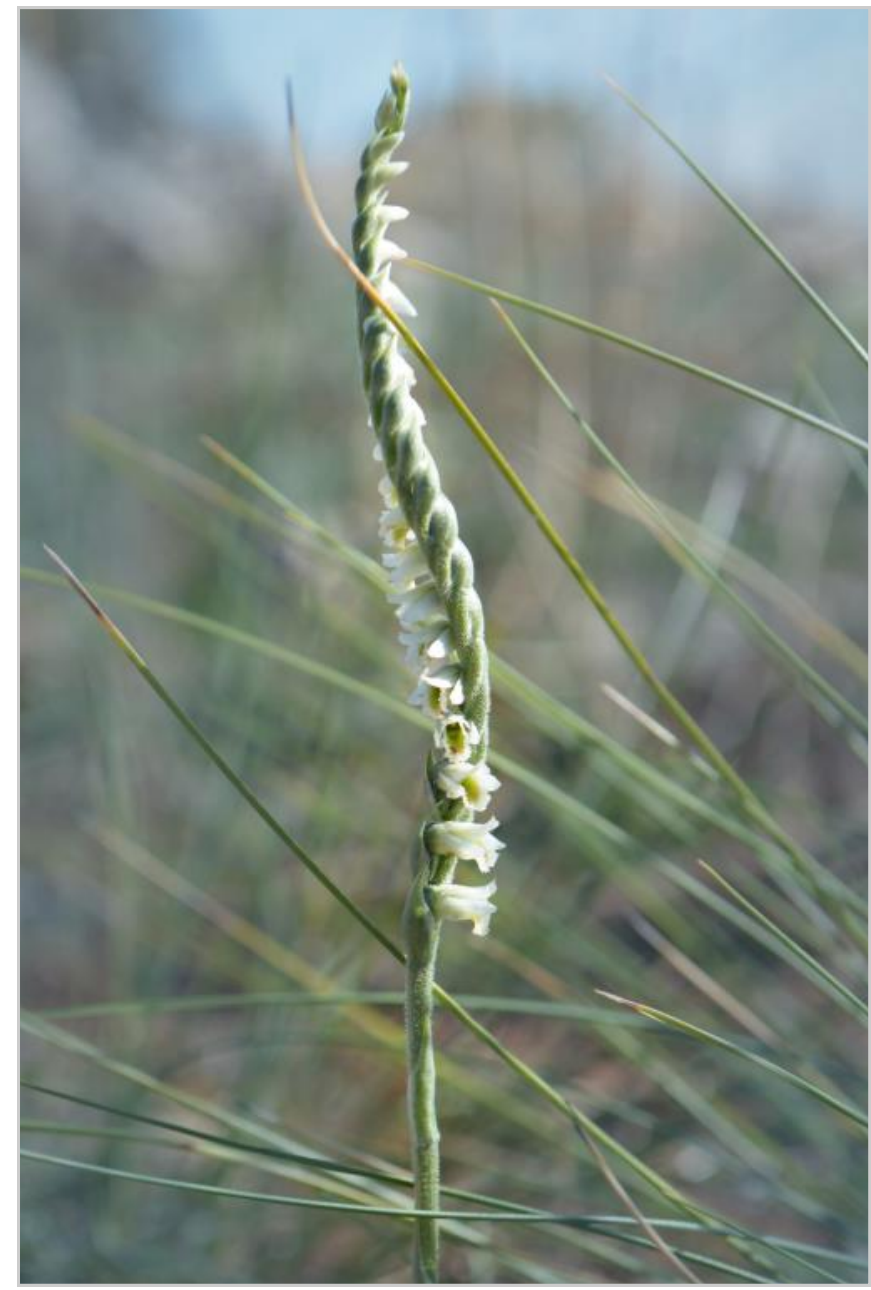

Spiranthes spiralis in Alta Murgia National Park, Puglia, Italy. Photo: R. Labadessa. 


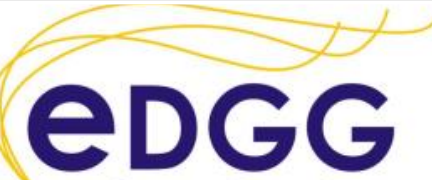

Grass[ลாள] research and conservation

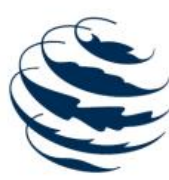
IAVS

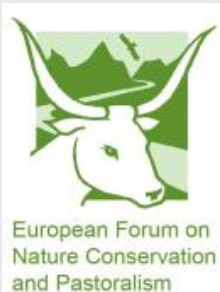

and Pastoralism
EDGG on the web:

http://www.edgg.org

EDGG in Facebook:

https://www.facebook.com/groups/938367279561202

EDGG on the ResearchGate

https://www.researchgate.net/project/EDGG-Eurasian-

DryGrassland-Group

The Eurasian Dry Grassland Group (EDGG), founded in 2008, is a working group of the International Association for Vegetation Science (IAVS) and member of the European Forum on Nature Conservation and Pastoralism (EFNCP). On 20 December 2019, it had 1326 members from 63 countries.

The Eurasian Dry Grassland Group (EDGG) is a network of researchers and conservationists interested in any type of Palaearctic natural and semi-natural grasslands. It is an official subgroup of IAVS (http://www.iavs.org) but one can join our group without being an IAVS member. We live from the activities of our members. Everybody can join the EDGG without any fee or other obligation.

The EDGG covers all aspects related to grasslands, in particular: plants - animals - fungi - microbia - soils - taxonomy - phylogeography - ecophysiology - population biology - species' interactions - vegetation ecology - syntaxonomy - landscape ecology - biodiversity - land use history - agriculture - nature conservation - restoration - environmental legislation - environmental education.

\section{EDGG Executive Committee and responsibilities of its members}

Alla Aleksanyan, Armenia, alla.alexanyan@gmail.com Chief Editor of the Website; Deputy Conference Coordinator; member of the Editorial Board of Palaearctic Grasslands

Didem Ambarlı, Turkey \& Germany, didem.ambarli@gmail.com

Conference Coordinator; Deputy Chief Editor of the Website; member of the Editorial Board of Palaearctic Grasslands

Idoia Biurrun, Spain, idoia.biurrun@ehu.es

Membership Administrator; Deputy Chief Editor of Palaearctic Grasslands; Deputy Field Workshop Coordinator

Jürgen Dengler, Switzerland, juergen.dengler@uni-bayreuth.de

Secretary-General; Coordinator for Special Features; Deputy Chief Editor of Palaearctic Grasslands
Iwona Dembicz, Poland \& Switzerland, i.dembicz@gmail.com Field Workshop Coordinator; member of the Editorial Board of Palaearctic Grasslands

Anna Kuzemko, Ukraine \& Czech Republic, anyameadow.ak@gmail.com

Chief Editor of Palaearctic Grasslands; Deputy Facebook Group Administrator

Péter Török, Hungary, molinia@gmail.com IAVS Representative and Treasurer; Deputy Coordinator for Special Features; Deputy Secretary-General; member of the Editorial Board of Palaearctic Grasslands

Stephen Venn, Finland, stephen.venn@helsinki.fi Facebook Group Administrator; member of the Editorial Board of Palaearctic Grasslands, Deputy Conference Coordinator

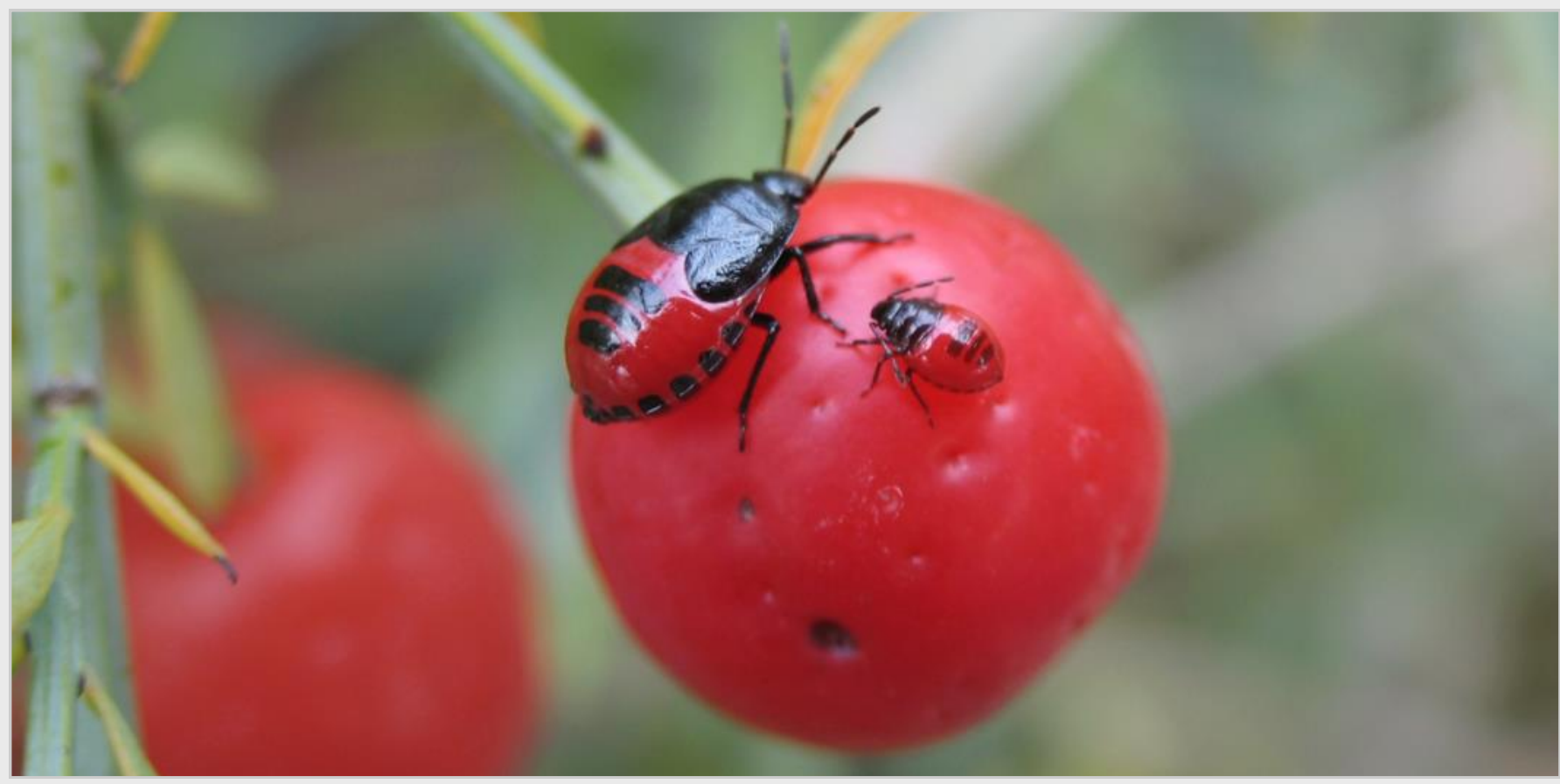

